\title{
Classification and Signaling Characteristics of 5-HT Receptors: Towards the Concept of 5-HT Receptosomes
}

Philippe Marin, Carine Bécamel, Séverine Chaumont-Dubel, Franck Vandermoere, Joël Bockaert, Sylvie Claeysen

IGF, Univ. Montpellier, CNRS, INSERM, Montpellier, France.

Corresponding author:

Dr Philippe Marin, Institut de Génomique Fonctionnelle, 141 rue de la Cardonille, 34094 Montpellier Cedex 5, France. Email: philippe.marin@,igf.cnrs.fr Phone: +33 434359242.

Other contact information:

Dr Carine Bécamel, Institut de Génomique Fonctionnelle, 141 rue de la Cardonille, 34094 Montpellier Cedex 5, France. Email: carine.becamel@igf.cnrs.fr Phone: +33 434359215.

Dr Séverine Chaumont-Dubel, Institut de Génomique Fonctionnelle, 141 rue de la Cardonille, 34094 Montpellier Cedex 5, France. Email: severine.chaumont-dubel@igf.cnrs.fr Phone: +33 434359205.

Dr Franck Vandermoere, Institut de Génomique Fonctionnelle, 141 rue de la Cardonille, 34094 Montpellier Cedex 5, France. Email: franck.vandermoere@,igf.cnrs.fr Phone: +33434 3592 13.

Prof Joël Bockaert, Institut de Génomique Fonctionnelle, 141 rue de la Cardonille, 34094 Montpellier Cedex 5, France. Email: joel.bockaert@igf.cnrs.fr Phone: +33 434359242.

Dr Sylvie Claeysen, Institut de Génomique Fonctionnelle, 141 rue de la Cardonille, 34094 Montpellier Cedex 5, France. Email: sylvie.claeysen@igf.cnrs.fr Phone: +33 434359215. 


\begin{abstract}
Serotonin (5-hydroxytryptamine, 5-HT) is one of the extracellular messengers capable of activating the largest number of receptors (17 receptors belonging to 7 classes $-5-\mathrm{HT}_{1-7}-$ defined first on a pharmacological basis and then on their gene sequence). Alternative splicing and RNA editing add to this diversity. Most of 5-HT receptors belong to the G protein-coupled receptor (GPCR) family except for $5-\mathrm{HT}_{3}$ receptors that are ionic channels. Their activation gives rise to a huge complexity of intracellular signaling events that depend or not on G protein activation and underlie the diversity of physiological functions of 5-HT. Assembly of 5-HT receptors into heteromers with distinct 5-HT receptors or other GPCRs, as well as their physical association with protein partners further increase the versatility of serotonergic signaling and the complexity of its regulation. These interactions also offer novel opportunities for therapeutic interventions in disorders related to dysfunctions of serotonergic systems.
\end{abstract}

\title{
Keywords
}

Serotonin, receptor, G protein, signaling, structure, heteromer, interactome, pharmacology 


\section{Introduction}

Among the most ancient signaling molecules, it is not surprising to find amino acids (such as glutamate and GABA) and their derivatives such as serotonin (5-hydrotryptamine, 5-HT). 5HT is present in plants and seeds. Since its discovery in Cowhage (Mucuna pruriens) in the 1950s, 5-HT has been found in more than 90 plant species, including banana, pineapple and walnuts (Erland et al., 2016). Banana skin contains 10 times more 5-HT than mammalian hippocampus. In addition to its anti-oxidant properties, 5-HT plays many physiological roles in plants such as growth, control of seasonal cycles, delay of senescence and responses to stress. However, no 5-HT receptors have been found in plants. It is only with the apparition of synapses 600 millions years ago that 5-HT receptors appeared in coelenterates (Cnidaria) (Hajj-Ali \& Anctil, 1997). Their expansion was very rapid. Seven 5-HT receptor subtypes are present in Caenorhabditis elegans, four in mollusks (Aplysia), and four or five in Drosophila melanogaster, honeybees (Apis mellifera) and crickets (Gryllus bimaculatus) (Blenau \& Thamm, 2011).

In invertebrates, particularly in insects, the classification and denomination of 5-HT receptors is based on the comparison of their primary sequences with those of vertebrate 5-HT receptors. Thus, drosophila and honeybee express homologues of vertebrate $5-\mathrm{HT}_{1}\left(5-\mathrm{HT}_{1 \mathrm{~A}}\right.$ and $\left.5-\mathrm{HT}_{1 \mathrm{~B}}\right)$, 5- $\mathrm{HT}_{2}\left(5-\mathrm{HT}_{2 \mathrm{~A}}\right.$ and 5- $\left.\mathrm{HT}_{2 \mathrm{~B}}\right)$ and $5-\mathrm{HT}_{7}$ receptors. With regard to evolution, it is worthy to note that invertebrate $5-\mathrm{HT}_{1}$ and $5-\mathrm{HT}_{7}$ receptors inhibit and stimulate cAMP production, respectively, reminiscent of vertebrate receptors. Due to the low interest of pharmaceutical companies for invertebrate 5-HT receptors, there are only a few drugs available for their characterization. Genetics and behavioral studies in invertebrates showed that 5-HT receptors are involved in important physiological functions, including sleep, associative learning, circadian rhythms, aggressive and social behaviors (Blenau \& Thamm, 2011). The most spectacular effect of 5-HT upon social behavior is its ability to induce in a few hours a switch from solitary to gregarious behavior in desert locust (Schistocerca gregaria) (Anstey et al., 2009; Rogers \& Ott, 2015). 
In vertebrates, the classification of 5-HT receptors started in 1953 with the description by Gaddum of the antagonist effect of lysergic acid diethylamide (LSD) on 5-HT-elicited responses in several in vitro pharmacological tests (Gaddum, 1953). The psychotropic and hallucinogenic effects of LSD were known since April 1943, when Albert Hofmann was disturbed by unusual sensations and hallucinations after he accidentally ingested the drug.

In 1957, Gaddum and Picarelli proposed the first classification of 5-HT receptors. 5-HTinduced contractions of guinea-pig ileum were blocked in part by dibenziline (D), an irreversible blocker of SH groups, and in part by morphine (M). They proposed that two receptors were involved, the $\mathrm{D}$ and $\mathrm{M}$ receptors localized on smooth muscle and nerve ganglia, respectively (Gaddum \& Picarelli, 1957) (Figure 1). We know, today, that D receptors correspond to muscle 5- $\mathrm{HT}_{2}$ receptor, a G protein-coupled receptor (GPCR) (Bradley et al., 1986) whereas the $M$ receptor corresponds to presynaptic cation-gated channels $\left(5-\mathrm{HT}_{3}\right.$ receptors) (Derkach et al., 1989).

In the 1970 s and early 1980 s, two novel methods based on new tools allowed a rapid advance in the discovery and classification of neurotransmitter receptors in general and of 5-HT receptors in particular. The first one was the binding of radiolabelled ligands on tissues. With regard to 5-HT receptors, the first ligands used were $\left[{ }^{3} \mathrm{H}\right]-5-\mathrm{HT},\left[{ }^{3} \mathrm{H}\right]$-LSD and $\left[{ }^{3} \mathrm{H}\right]$-spiperone (a $\mathrm{D}_{2}$ and 5-HT $2 \mathrm{~A}$ antagonist) and were followed by many others (Bennett \& Aghajanian, 1974; Fillion et al., 1976; Hoyer et al., 1994; Peroutka et al., 1979, 1981; Peroutka \& Snyder, 1979). The second method was the measurement of second messenger (cyclic AMP, inositol triphosphate (IP3), $\mathrm{Ca}^{2+}$ ) production in cells or isolated membranes to monitor and pharmacologically characterize 5-HT-induced responses (Bockaert et al., 2006; Bockaert et al., 2008; Bouhelal et al., 1988; Dumuis et al., 1988). This last approach had the advantage of revealing immediately the agonist or antagonist nature of the compounds tested. This pharmacological period clearly characterized 4 classes of receptors $\left(5-\mathrm{HT}_{1}\right.$ to $\left.5-\mathrm{HT}_{4}\right)$ and most of their subtypes (Hoyer et al., 1994) (Figure 1). In 1988, the first 5-HT receptor (5-HT $1 \mathrm{~A})$ was cloned (Fargin et al., 1988), launching the cloning period. In addition to the cloning of 5-HT receptors belonging to pharmacologically defined classes, three receptors (the $5-\mathrm{HT}_{5}, 5-\mathrm{HT}_{6}$ 
and $5-\mathrm{HT}_{7}$ receptors) were cloned. In total, at least 14 receptor subtypes have been cloned. All are GPCRs except for 5-HT 3 receptors that are ionic channels (Derkach et al., 1989; Hoyer et al., 1994; McCorvy \& Roth, 2015) (Figure 1).

\section{I- The four 5-HT receptor classes discovered before the cloning era}

At the beginning of the $70 \mathrm{~s}$, there has been a great development of what was called "binding experiments" for searching and characterizing hormone and then neurotransmitter receptors. Laboratories used radioactive ligands, labeled with tritium $\left[{ }^{3} \mathrm{H}\right]$ or iodine (generally $\left[{ }^{125} \mathrm{I}\right]$ ) to detect and pharmacologically characterize receptors. The three pioneer laboratories in binding experiments in the 5-HT receptor field are those of Fillion who used $\left[{ }^{3} \mathrm{H}\right]-5-\mathrm{HT}$ (Fillion et al., 1976), Aghajanian who used $\left[{ }^{3} \mathrm{H}\right]-\mathrm{LSD}$ (Bennett \& Aghajanian, 1974) and Snyder who used

both ligands together with $\left[{ }^{3} \mathrm{H}\right]$-spiperone (Peroutka et al., 1981). Peroutka and Snyder demonstrated that $\left[{ }^{3} \mathrm{H}\right]-5$-HT binds with a high affinity $(\mathrm{nM})$ to a class of 5-HT receptors designated as $5-\mathrm{HT}_{1}$, whereas $\left[{ }^{3} \mathrm{H}\right]$-spiperone, and later on $\left[{ }^{3} \mathrm{H}\right]$-ketanserin, bind to another receptor, the 5- $\mathrm{HT}_{2}$ receptor that has high affinity for spiperone but a low affinity $(\mu \mathrm{M})$ for 5 HT (Peroutka et al., 1981; Peroutka \& Snyder, 1979). [ $\left.{ }^{3} \mathrm{H}\right]-\mathrm{LSD}$ binds to both receptors.

\section{$5-\mathrm{HT}_{1}$ class}

5- $\mathrm{HT}_{1}$ receptors were rapidly subdivided into 5- $\mathrm{HT}_{1 \mathrm{~A}}$ and $5-\mathrm{HT}_{1 \mathrm{~B}}$ receptors (Figure 1). The 5$\mathrm{HT}_{1 \mathrm{~A}}$ receptor was first described as the $\left[{ }^{3} \mathrm{H}\right]-5-\mathrm{HT}$ binding displaced by spiperone (Pedigo et al., 1981). Thereafter, 8-OH-DPAT, a selective and high-affinity 5-HT $\mathrm{HA}_{1 \mathrm{~A}}$ receptor ligand, was discovered (Middlemiss \& Fozard, 1983) and radiolabelled by Gozlan et al. (Gozlan et al., 1983). Further studies showed that $5-\mathrm{HT}_{1 \mathrm{~A}}$ receptor stimulation inhibits cAMP production in both hippocampal membranes (De Vivo \& Maayani, 1986) and primary neurons (Bockaert et al., 1987; Weiss et al., 1986).

In contrast, 5- $\mathrm{HT}_{1 \mathrm{~B}}$ receptor corresponded to $\left[{ }^{3} \mathrm{H}\right]-5-\mathrm{HT}$ binding not displaced by spiperone or 8-OH-DPAT and labeled with $\left[{ }^{125} \mathrm{I}\right]$-cyanopindolol, a $\beta$-adrenergic blocker (Hoyer et al., 1985). We found that this presynaptic receptor is negatively coupled to adenylyl cyclase in substantia nigra (Bouhelal et al., 1988). Initially, all binding experiments on 5-HT $1 \mathrm{~B}$ receptor 
were done in rodents. However, the surprise came when it was found that $\left[{ }^{125} \mathrm{I}\right]$-cyanopindolol does not bind to $5-\mathrm{HT}_{1 \mathrm{~B}}$ receptor in guinea-pig, pig, and human brain. Thereafter, a receptor having very similar pharmacological properties (except for its low affinity for $\beta$-adrenergic antagonists) and the same ability to inhibit 5-HT release and cAMP production in those species was described. This receptor thought to be present only in some species such as pig and human (Hoyer \& Middlemiss, 1989; Schoeffter \& Hoyer, 1989) was called 5-HT1D. The cloning of two genes (initially called $H T 1 R D \alpha$ and $H T 1 R D \beta$ ) in human that share very similar sequences and encode receptors with common 5- $\mathrm{HT}_{1 \mathrm{~B} / \mathrm{D}}$ pharmacology led to the proposal that the $5-\mathrm{HT}_{1 \mathrm{~B}}$ receptor is coded by the $H T 1 R D \beta$ gene whereas the 5-HT $\mathrm{HT}_{1 \mathrm{D}}$ receptor is coded by the HTIRD $\alpha$ gene in all species. It was later found that the absence of binding of $\left[{ }^{125} \mathrm{I}\right]$-cyanopindolol to the human $5-\mathrm{HT}_{1 \mathrm{~B}}$ receptor is due to a single residue difference in the transmembrane 7 (TM7) (an asparagine in human and a threonine in rodents). The current gene nomenclature is HTR $1 B$ and HTR1D for the 5-HT $\mathrm{HT}_{1 \mathrm{~B}}$ and $5-\mathrm{HT}_{1 \mathrm{D}}$ receptors. The 5-HT $1 \mathrm{~B}$ receptor is largely predominant in terms of expression and function. The anti-migraine drug Sumatriptan, which was developed as a selective "5-HT $\mathrm{HT}_{1}$-like" receptor agonist, is in fact a 5-HT $1 \mathrm{~B} / 1 \mathrm{D}$ receptor agonist (Humphrey, 2008). However, triptans may also interact with 5-HT 1 F sites (Waeber \& Moskowitz, 1995) (see below). Whether the effects of sumatriptan are mediated by vascular vs. neuronal receptors is still a matter of debate.

The 5-HT $1 \mathrm{C}$ receptor had a brief existence in the 5-HT 1 class. Found in choroid plexus and later on in many brain areas using $\left[{ }^{3} \mathrm{H}\right]-5-\mathrm{HT}$ binding, it was rapidly shown to be coupled to phospholipase C (PLC), as shown for 5- $\mathrm{HT}_{2 \mathrm{~A}}$ receptors (Berg et al., 1998). After its cloning, it became evident that it has high sequence homology with $5-\mathrm{HT}_{2}$ receptors and a similar pharmacology. The 5-HT $1 \mathrm{C}$ receptor was thus definitely classified in the 5- $\mathrm{HT}_{2}$ family and renamed $5-\mathrm{HT}_{2 \mathrm{C}}$ receptor.

5-ht $\mathrm{t}_{\mathrm{E}}$ binding sites were first discovered using $\left[{ }^{3} \mathrm{H}\right]-5-\mathrm{HT}$ binding in human frontal cortical tissue and then in bovine but not in rat brain (Leonhardt et al., 1989). Their high affinity for $\left[{ }^{3} \mathrm{H}\right]-5-\mathrm{HT}$ and low affinity for drugs displaying affinity for $5-\mathrm{HT}_{2}$ receptors (i.e. mesulergine) led to its classification as a $5-\mathrm{HT}_{1}$ receptor. Its weak affinity for the prototypical 5-HT 1 receptor 
agonist, 5-carboxamidotryptamine (5-CT), categorized it as a new member of the 5-HT 1 class (Leonhardt et al., 1989). A receptor with similar pharmacological properties to the $5-\mathrm{HT}_{1 \mathrm{E}}$ binding sites (Levy et al., 1992) and thus named 5-HT $1 \mathrm{E}$ receptor was then cloned. However, the subsequently cloned $5-\mathrm{HT}_{1 \mathrm{~F}}$ shares a high degree of homology and pharmacology similarities with the 5-ht $\mathrm{fE}_{\mathrm{E}}$ binding sites, compared to other 5-HT receptors (Adham et al., 1993) and it is likely that the initially identified 5-ht $1 \mathrm{E}$ binding sites correspond to both 5-HT $1 \mathrm{E}$ and 5$\mathrm{HT}_{1 \mathrm{~F}}$ receptors. No drugs that can discriminate between these two receptor subtypes are currently available.

\section{$5-\mathrm{HT}_{2}$ class}

The 5- $\mathrm{HT}_{2 \mathrm{~A}}$ receptors correspond to the $5-\mathrm{HT}_{2}$ receptors initially identified as $\left[{ }^{3} \mathrm{H}\right]$-spiperone and $\left[{ }^{3} \mathrm{H}\right]$-ketanserin binding sites with low (micromolar) affinity for 5-HT and the "D receptor" identified by Gaddum and Picarelli (Peroutka \& Snyder, 1979). They are not only expressed in the brain but also at the periphery, especially in platelets where they mediate aggregation and in smooth muscles where they trigger contraction.

The 5- $\mathrm{HT}_{2 \mathrm{~B}}$ receptor was first characterized in rat stomach fundus where it stimulates muscle contraction and was transiently named " $5-\mathrm{HT}_{1 \mathrm{~F}}$ ". Its pharmacology has some similarities to that of 5-HT $\mathrm{HC}_{2 \mathrm{C}}$ receptors. After its cloning in 1992 in rodents (Foguet et al., 1992) and human (Hoyer et al., 1994; McCorvy \& Roth, 2015), it became clear that this receptor belongs to the 5-HT2 class but is distinct from 5- $\mathrm{HT}_{2 \mathrm{C}}$ receptors. It was thus named 5- $\mathrm{HT}_{2 \mathrm{~B}}$ receptor (Figure 1). It has a wide distribution pattern both at the periphery and the brain (McCorvy \& Roth, 2015). Activation of $5-\mathrm{HT}_{2 \mathrm{~B}}$ receptor is responsible for abnormal echocardiograms, pulmonary hypertension, cardiac valve deficiencies triggered by the fenfluramine metabolite norfenfluramine, a drug inducing a weight loss initially marketed by Wyeth (Roth, 2007).

The discovery and pharmacological characteristics of the 5- $\mathrm{HT}_{2 \mathrm{C}}$ receptor that was first thought to belong to the $5-\mathrm{HT}_{1}$ class, are described above. 


\section{$5-\mathrm{HT}_{3}$ class}

Initially named "M receptors" by Gaddum and Picarelli (Gaddum \& Picarelli, 1957), 5-HT3 receptors have been extensively studied for three decades in the periphery before the discovery that they are cation channels (Derkach et al., 1989) and that a radiolabelled compound $\left(\left[{ }^{3} \mathrm{H}\right]-\right.$ ICS 205-930 (tropisetron, 31-tropanyll-1H-indole-3-carboxylic acid ester) (Waeber et al., 1989) could be used for studying their distribution. 5- $\mathrm{HT}_{3}$ receptors show a wide distribution in the brain, are responsible for the depolarizing effects of 5-HT and mediate peripheral neuronal transmitter release, emesis and nociception (Hoyer et al., 1994; Waeber et al., 1989). Five genes encoding 5-HT 3 receptor subunits $\left(5-\mathrm{HT}_{3 \mathrm{~A}-\mathrm{E}}\right)$ have been cloned in human and some other vertebrates (but not in rodents), while 5- $\mathrm{HT}_{3}$ receptors seem to be absent in invertebrates (Niesler et al., 2008) (Figure 1). These subunits have a high level of homology with other members of the Cys-Cys loop ligand-gated channel superfamily (e.g. nicotinic, $\mathrm{GABA}_{\mathrm{A}}$ and glycine receptors). However, the most studied ones are 5- $\mathrm{HT}_{3 \mathrm{~A}}$ and $5-\mathrm{HT}_{3 \mathrm{~B}}$ receptors. Native 5$\mathrm{HT}_{3}$ receptors have a pentameric structure, as revealed by electron microscopy (Boess et al., 1995). In order to form an active receptor, at least one 5- $\mathrm{HT}_{3 \mathrm{~A}}$ subunit has to be present. Functional receptors can be formed by co-assembling 5-HT 3 A subunits only, whereas receptors exclusively composed of 5-HT3в subunits are not functional (Barnes \& Sharp, 1999). Native 5$\mathrm{HT}_{3}$ receptors are likely a co-assembling of 5- $\mathrm{HT}_{3 \mathrm{~A}}$ and $5-\mathrm{HT}_{3 \mathrm{~B}}$ subunits and, possibly, some 5-HT3C-E subunits. The stoichiometry of the different subunits constituting native pentameric receptors has not yet been clearly determined (Niesler et al., 2008).

\section{$5-\mathrm{HT}_{4}$ receptor}

In contrast to other G protein-coupled 5-HT receptors, the 5- $\mathrm{HT}_{4}$ receptor has been discovered through its capacity to stimulate production of cAMP. Our laboratory identified an atypical 5HT receptor positively coupled to the adenylyl cyclase both in colliculi neurons (Dumuis et al., 1988) and guinea-pig hippocampus (Bockaert et al., 1990). It was insensitive to 5-HT 1 and 5$\mathrm{HT}_{2}$ receptor antagonists and was inhibited (with a very low affinity) by some, but not all, 5$\mathrm{HT}_{3}$ receptor antagonists. Since it was obviously not a 5-HT $1-3$ receptor, it was named "5-HT 4 receptor" (Figure 1). 2-methoxy-4-amino-5-chloro benzamides such as metoclopramide or 
cisapride are potent agonists of the 5- $\mathrm{HT}_{4}$ receptor (Dumuis et al., 1989). This pharmacology was sufficient to propose that the $5-\mathrm{HT}_{4}$ receptor described in neurons was similar to a gastroprokinetic 5-HT receptor insensitive to $5-\mathrm{HT}_{1-3}$ antagonists and stimulated by benzamides in guinea-pig ileum and more largely in gastro-intestinal tract (Bockaert et al., 1992). 5-HT4 receptor agonists have been commercialized for gastro-intestinal problems such as idiopathic constipation and gastro-oesophagial reflux (Bockaert et al., 2008). A recent study showed that gut bacteria are able to produce tryptamine and to increase gastrointestinal transit by activating peripheral 5-HT $\mathrm{HT}_{4}$ receptors (Bhattarai et al., 2018). De Vadder et al. demonstrated that maturation of peripheral nervous system is likewise under the control of gut microbiota through 5-HT release and 5- $\mathrm{HT}_{4}$ receptor activation (De Vadder et al., 2018). In brain, several pathologies, such as Alzheimer's disease (AD), feeding disorders and depression, might benefit from 5-HT 4 receptor-directed therapies (Bockaert et al., 2011; Claeysen et al., 2012). Chronic administration of 5- $\mathrm{HT}_{4}$ receptor agonists decreases the amyloid pathology and prevents the appearance of cognitive deficits in a mouse model of AD (Baranger et al., 2017; Giannoni et al., 2013). In line with these results, an innovative multitarget-directed ligand, named donecopride, has been developed against AD. This molecule simultaneously activates $5-\mathrm{HT}_{4}$ receptors and inhibits acetylcholinesterase (Lecoutey et al., 2014; Rochais et al., 2015).

\section{II- The three 5-HT receptor classes discovered by homology cloning}

The cloning of rhodopsin and some adrenergic and muscarinic receptors revealed the existence of a GPCR family that shares high sequence similarity throughout their seven transmembrane domains. Using cross-hybridization at reduced stringency with the full length $\beta_{2}$-adrenergic receptor, Fargin et al. (Fargin et al., 1988) cloned the first 5-HT receptor (the 5-HT $\mathrm{HA}_{1 \mathrm{~A}}$ receptor). Thereafter, the cloning of 5- $\mathrm{HT}_{1-4}$ receptors described in the previous chapter by using similar technologies was quite rapid. However, some clones did not correspond to previously described receptors and thus allowed the discovery of three novel $5-\mathrm{HT}$ receptors, the $5-\mathrm{HT}_{5}, 5-\mathrm{HT}_{6}$ and $5-\mathrm{HT}_{7}$ receptors.

\section{5-HT5 receptors}

In 1992, Plassat et al. cloned a new 5-HT receptor with a sequence quite different from those 
of the previously identified 5-HT receptors and that display a high affinity for LSD (Plassat et al., 1992). Therefore, they named it 5- $\mathrm{HT}_{5}$ (now 5-HT $5 \mathrm{~A}$ ). The same laboratory cloned one year later a second 5-HT5 receptor that was called 5-ht 5-HT $\mathrm{H}_{5 \mathrm{~A}}$ receptor pharmacological tools has been difficult but led to the quite selective antagonists SB699551 (Corbett et al., 2005) and ASP5736 (Yamazaki et al., 2014) that are now widely used in functional studies. The distribution of $5-\mathrm{HT}_{5 \mathrm{~A}}$ receptors suggests a possible role in emotion regulation, cognition, anti-nociception, and control of circadian rhythm (Plassat et al., 1992). RNA-seq analysis confirmed that the expression of this receptor is restricted to the brain and the testis (Fagerberg et al., 2014). In contrast to the 5-HT $5 \mathrm{~A}$ receptor, the 5-ht $5 \mathrm{~B}$ was not conserved during evolution and leads to a pseudogene in human (Grailhe et al., 2001).

\section{5-HT 6 receptor}

It is also in the 1990s that the 5-HT 6 receptor was originally cloned in rat (Monsma et al., 1993; Ruat, Traiffort, Arrang, et al., 1993) and a few years later in human (Kohen et al., 1996) and mouse (Kohen et al., 2001). It is almost exclusively detected in brain. Selective agonists including WAY181187, WAY208466 (Schechter et al., 2008) and ST1936 (Borsini et al., 2015) as well as antagonists such as SB258585, SB271046 and SB399885 (Hirst et al., 2006) have been synthetized. [ $\left.{ }^{125} \mathrm{I}\right]-\mathrm{SB} 258585$ is the most selective radioligand available (Hirst et al., 2006). Studies of brain distribution of $5-\mathrm{HT}_{6}$ receptors, assessed by mRNA localization, $\left[{ }^{125} \mathrm{I}\right]-$ SB258585 binding and immunohistochemistry, indicate their presence in hypothalamus, hippocampus, mesencephalon, cerebral cortex, olfactory bulb, with the higher density in dorsal striatum in rat and human but not in mice (Gerard et al., 1997; Hirst et al., 2003; Marazziti et al., 2013). The neuronal expression profile indicates localization in both glutamatergic and GABAergic neurons in the cortex (in particular GABAergic neurons that express $5-\mathrm{HT}_{3}$ receptors) and the hippocampus. In the striatum, 5- $\mathrm{HT}_{6}$ receptors are found in medium sized spiny neurons expressing $\mathrm{D}_{1}$ or $\mathrm{D}_{2}$ dopaminergic receptors and some cholinergic neurons (Helboe et al., 2015). Further studies revealed that 5- $\mathrm{HT}_{6}$ receptors are mainly located in primary cilium and also in dendrites (Brailov et al., 2000; Brodsky et al., 2017). A specific sequence in the third intracellular loop of the mouse 5-HT 6 receptor and other GPCRs known 
to be targeted in primary cilium has been demonstrated to be responsible for this intriguing localization (Berbari et al., 2008).

Preclinical studies revealed that $5-\mathrm{HT}_{6}$ receptor blockade induces pro-cognitive effects in a wide range of cognition paradigms in rodents, raising some hope that 5 - $\mathrm{HT}_{6}$ receptors could be an interesting target for treating cognitive deficits of neuropsychiatric disorders such as AD and other dementia (de Jong \& Mork, 2017) as well as schizophrenia (Meffre et al., 2012). However, a first clinical trial of Idalopirdine, a 5- $\mathrm{HT}_{6}$ receptor antagonist developed by Lundbeck/Otsuka, given in association with the acetylcholinesterase inhibitor Donepezil, failed in Phase III for AD (Mullard, 2016). Two others trials are on-going. Similarly, a Phase IIb trial performed with another antagonist developed by Axovant, Intepirdine (SB742458), in patients with dementia with Lewy bodies, was also negative. The 5- $\mathrm{HT}_{6}$ receptor has also been proposed as target for the treatment of depression (Svenningsson et al., 2007) and obesity (Heal et al., 2008).

\section{5-HT 7 receptor}

The 5-HT 7 was the last 5-HT receptor to be cloned from 1993 by several groups in mouse (Plassat et al., 1993), rat (Lovenberg et al., 1993; Meyerhof et al., 1993; Ruat, Traiffort, Leurs, et al., 1993) human (Bard et al., 1993), guinea-pig (Tsou et al., 1994) and pig (Bhalla et al., 2002). "5-HT 7 like" receptors have also been cloned in Xenopus laevis (Nelson et al., 1995), C. elegans (Hobson et al., 2003) and honeybee (Schlenstedt et al., 2006). The pharmacology of 5$\mathrm{HT}_{7}$ receptors is characterized by a high affinity for agonists generally known to act on 5-HT 1 receptors, such as 5-carboxytryptamine and 8-OH-DPAT, and antagonists known to act on 5$\mathrm{HT}_{2}$ receptors, such as cyproheptadine and clozapine. Crystal structure of the 5- $\mathrm{HT}_{7}$ receptor should reveal the residues responsible for this singularity. Notably, LSD, which is an agonist (often partial) of most 5-HT receptor subtypes, is an antagonist of the 5- $\mathrm{HT}_{7}$ receptor (Wacker et al., 2013). The most potent and selective 5- $\mathrm{HT}_{7}$ receptor agonists are the aminotetraline derivatives AS19 and E-55888 (Brenchat et al., 2009). SB269970 is the prototypic 5-HT receptor antagonist that has been used as a radiolabelled form $\left(\left[{ }^{3} \mathrm{H}\right]-\mathrm{SB} 269970\right)$ in binding experiments (Hagan et al., 2000; D. R. Thomas et al., 2000). In human, high 5- $\mathrm{HT}_{7}$ receptor density was found in thalamus, hypothalamus, hippocampus, caudate nucleus, putamen and 
substantia nigra (Varnas et al., 2004). Immunohistochemistry confirmed this localization and showed additional expression in suprachiasmatic nuclei (Neumaier et al., 2001), spinal cord dorsal horn (Doly et al., 2005) and myenteric neurons (Tonini et al., 2005). Experiments using selective antagonists and sometimes $5-\mathrm{HT}_{7}$ receptor knockout mice have implicated this receptor in numerous CNS functions, including neuronal morphogenesis, circadian rhythm, rapid eye movement (REM) sleep, thermoregulation, and memory (Matthys et al., 2011). 5-HT7 receptor antagonists have been suggested to be of interest for the treatment of cognitive deficits of schizophrenia. They attenuate reversal learning deficits as well as deficit in novel object recognition induced by phencyclidine (PCP) treatment in the rat (Horiguchi et al., 2011; McLean et al., 2009). Blockade of 5- $\mathrm{HT}_{7}$ receptors may also have therapeutic implications for treating negative symptoms in schizophrenia since SB269970 administration ameliorates both ketamine and PCP-induced social withdrawal in rats (Nikiforuk et al., 2013). On the other hand, activation of $5-\mathrm{HT}_{7}$ receptors corrects molecular, electrophysiological, and behavior abnormalities in mice models of Fragile X syndrome (FXS) (Costa et al., 2015). Finally, in rat models of neuropathic pain, SB269970 reduces hyperalgesia and tactile allodynia (AmayaCastellanos et al., 2011).

\section{III- Some light on the pharmacology and signaling of 5-HT receptors given by their 3D structure}

Several 5-HT receptor structures have been solved by X-ray crystallography or cryo-EM (Garcia-Nafria et al., 2018; Hassaine et al., 2014; Peng et al., 2018; Wacker et al., 2013; Wacker et al., 2017; C. Wang et al., 2013). 5-HT 1 B receptors have been crystallized in presence of ergotamine and dihydroergotamine (C. Wang et al., 2013), the 5- $\mathrm{HT}_{2 \mathrm{~B}}$ receptor in presence of ergotamine (Wacker et al., 2013) and LSD (Wacker et al., 2017) and the 5-HT2C receptor in presence of ergotamine and ritanserin, an inverse agonist (Peng et al., 2018). The ergotamine binding site in 5-HT $1 \mathrm{~B}$ receptors is defined by helices III, V, VI, and the extracellular loop (ecl)2. It includes two pockets, an orthosteric pocket equivalent to that of other aminergic GPCRs and an extended pocket localized less deeply within the receptor that binds the cyclic tripeptide moiety of ergotamine (Figure 2A) (Wacker et al., 2013). The ergoline ring of 
ergotamine, as 5-HT, binds to the receptor through a salt bridge formed between its positively charged nitrogen and the conserved D1293.32. A hydrophobic cleft, composed of C133 $3^{3.36}$, $\mathrm{I} 130^{3.33}, \mathrm{~W} 327^{6.48}, \mathrm{~F} 330^{6.51}$ and $\mathrm{F} 331^{6.52}$ side chains, packs the planar ergoline ring. The orthosteric pocket of the $5 \mathrm{HT}_{2 \mathrm{~B}}$ receptor is very similar to that of the $5-\mathrm{HT}_{1 \mathrm{~B}}$ receptor. The extended pocket of the $5-\mathrm{HT}_{1 \mathrm{~B}}$ receptor located above the orthosteric pocket is broader than that of the $5-\mathrm{HT}_{2 \mathrm{~B}}$ receptor, because the equivalent of $\mathrm{M} 218^{5.39}$ in the $5-\mathrm{HT}_{2 \mathrm{~B}}$ receptor is a smaller threonine residue (T2095.39) (C. Wang et al., 2013). The phenyl ring of the cyclic tripeptide moiety of ergotamine contacts with $\mathrm{L} 347^{6.58}$ and $\mathrm{V} 348^{6.59}$ in the $5-\mathrm{HT}_{2 \mathrm{~B}}$ receptor, whereas it rotates to occupy a cavity close to $\mathrm{T} 209^{5.39}$ at helix $\mathrm{V}$ in the 5 - $\mathrm{HT}_{1 \mathrm{~B}}$ receptor (Figure 2B). The extended pocket in the 5- $\mathrm{HT}_{1 \mathrm{~B}}$ receptor described above receives the large substitution at the 5 ' position of the indole of triptans, the most frequently prescribed anti-migraine medications, whereas the narrow pocket of the 5- $\mathrm{HT}_{2 \mathrm{~B}}$ receptor is not favorable for the binding of these drugs (C. Wang et al., 2013). Simulation of norfenfluramine binding to 5-HT 1 в and 5$\mathrm{HT}_{2 \mathrm{~B}}$ receptors indicates that in the 5- $\mathrm{HT}_{2 \mathrm{~B}}$ receptor, $\mathrm{F} 217^{5.38}$ and $\mathrm{M} 218^{5.39}$ form a hydrophobic pocket otherwise absent in the $5-\mathrm{HT}_{1 \mathrm{~B}}$ receptor, which receives the trifluoromethyl group of norfenfluramine (C. Wang et al., 2013). One of the interesting characteristics of ergotamine and LSD is their potent arrestin-biased signaling $v s . \mathrm{G}_{\mathrm{q}}$ signaling at $5-\mathrm{HT}_{2 \mathrm{~A}}$ and $5-\mathrm{HT}_{2 \mathrm{~B}}$ receptors. The high residency of LSD in 5- $\mathrm{HT}_{2 \mathrm{~A}}$ and $5-\mathrm{HT}_{2 \mathrm{~B}}$ receptors (more than $200 \mathrm{~min}$ ) and the slow but important recruitment of arrestin that is important for LSD hallucinogenic effects is due to LSD interaction with the ec12 loop (L209 in the 5-HT $2 \mathrm{~B}$ receptor) forming a lid above the binding site (Wacker et al., 2017). Cryo-EM structure of agonist-bound 5-HT $\mathrm{H}_{1 \mathrm{~B}}$ receptor coupled to $\mathrm{G}_{\mathrm{o}}$ indicates that the intracellular domain of the receptor is in a similar conformation to that observed for other amine receptors in complex with $G_{s}$, but with a smaller receptor:G protein interface, suggesting difference in coupling and signaling kinetics (Garcia-Nafria et al., 2018).

Crystallization of the 5- $\mathrm{HT}_{2 \mathrm{C}}$ receptor bound to ergotamine (Peng et al., 2018) confirmed the binding orthosteric pocket of $5-\mathrm{HT}_{1 \mathrm{~B}}$ and $5-\mathrm{HT}_{2 \mathrm{~B}}$ receptors and provided a complete resolution of extracellular loops that were disordered in the other serotonin receptor crystal structures 
(Peng et al., 2018) (Figure 2C). The 5-HT2C-ritanserin crystals revealed the inactive form of serotonin receptors, a conformation close to the inactive state structure of $\beta_{2}$-adrenergic receptor (Rasmussen et al., 2011). Interestingly and compared with the orthosteric pocket in other aminergic receptors, the inverse agonist ritanserin bound to one helical turn deeper in the transmembrane domains (Peng et al., 2018) (Figure 2D). This deep pocket includes interactions with residues F328 6.52 and W324 $4^{6.48}$, two key elements of GPCR activation by "toggle switch" of helix VI. The deep binding of ritanserin seems to prevent this activation switch, highlighting inverse agonist action mode on this receptor.

\section{IV- Gene structure of 5-HT receptors and editing}

The gene structure of human 5-HT receptors differs between receptor classes (Figure 3), in line with their phylogeny (Barnes \& Sharp, 1999). Only 5-HT 1 receptors are encoded by monointronic genes. The coding sequences of 5- $\mathrm{HT}_{2}$ receptors are split into three to four exons. Splicing site positions are conserved between 5- $\mathrm{HT}_{2 \mathrm{~A}-\mathrm{C}}$ receptors. 5- $\mathrm{HT}_{3}$ receptors genes are highly fragmented and two to five splice variants have been actually described for each gene, with the exception of $5-\mathrm{HT}_{3 \mathrm{C}}$ receptor gene. Most of these splice variants differ in the Nterminal region of the protein. The 5- $\mathrm{HT}_{2 \mathrm{~A}}$ receptor gene presents an in frame internal splicing site, leading to different coding sequences within the transmembrane domains III and IV. The fragmented gene of the 5- $\mathrm{HT}_{4}$ receptor gene encodes at least ten splice variants (Bender et al., 2000). Nine of them differ in the length and composition of the C-terminal domain after a common splicing site. An internal in-frame splice variant, in combination with the 5-HT4(b) isoform has also been described. This alternative modification of ecl 2 might combine with all the C-terminal variations, leading to a plethora of possibilities. The 5- $\mathrm{HT}_{5 \mathrm{~A}}$ and $5-\mathrm{HT}_{6}$ receptors are encoded by two and three exons, respectively, whereas the 5-ht5 receptor has been lost during evolution and corresponds to a pseudogene in human (Grailhe et al., 2001). Similarly to the 5-HT4 receptor, three C-terminal splice variants are generated from a common splicing site in the $5-\mathrm{HT}_{7}$ receptor gene.

In addition to the 5-HT receptors and splice variants encoded by the 17 human genes, RNA editing of the $5-\mathrm{HT}_{2 \mathrm{C}}$ receptor generates additional diversity. Five positions in its second coding 
exon can undergo adenosine to inosine (A to I) substitution: four major sites termed A to D and one less-frequent site, termed E. The second intracellular loop of the receptor is then theoretically capable of presenting 24 different variations from the non-edited form (INI) to the fully edited form (VGV) (Fitzgerald et al., 1999). Editing of the 5-HT2C receptor is tissuespecific and regulated by 5-HT. Low levels of 5-HT favor the expression of forms presenting a high affinity for 5-HT (Gurevich, Englander, et al., 2002). In suicide patients, altered editing of the 5- $\mathrm{HT}_{2 \mathrm{C}}$ receptor results in the expression of edited receptor forms exhibiting decreased basal activity and decreased agonist affinity and potency (Gurevich, Tamir, et al., 2002). In addition to its role in major depression, altered editing of the $5-\mathrm{HT}_{2 \mathrm{C}}$ receptor has been reported in Prader-Willy syndrome patients (Glatt-Deeley et al., 2010) and autistic individuals (Eran et al., 2013).

\section{V-Canonical signaling events engaged by 5-HT receptors}

\section{5-HT ${ }_{1 \mathrm{~A}}$ receptor}

A wealth of information on 5- $\mathrm{HT}_{1 \mathrm{~A}}$ receptor signaling has been collected through transfection of the receptor in diverse heterologous systems. In most models, its activation of Ga $\alpha_{i}$ leads to the inhibition of adenylyl cyclase, lowering intracellular cAMP concentration (Figure 4A). However, other pathways seem to be involved in the regulation of cAMP levels by $5-\mathrm{HT}_{1 \mathrm{~A}}$ receptors. Indeed, 5- $\mathrm{HT}_{1 \mathrm{~A}}$ receptor can increase cAMP formation in cellular models expressing the adenylyl cyclase II variant, including hippocampal neurons (Albert et al., 1999; Cadogan et al., 1994; Shenker et al., 1987). One of the principal 5-HT $1 \mathrm{~A}$ receptor effectors is the G proteingated inward rectifying $\mathrm{gK}^{+}(\mathrm{GIRK})$ channel (Figure 4), which opens following the stimulation of 5- $\mathrm{HT}_{1 \mathrm{~A}}$ receptor, leading to the inhibition of voltage-gated $\mathrm{Ca}^{2+}$ channels. Interestingly, this functional coupling between $5-\mathrm{HT}_{1 \mathrm{~A}}$ receptors and GIRK channels is enhanced in tyrosine hydroxylase 2 knockout mice, which exhibit a functional sensitization of $5-\mathrm{HT}_{1 \mathrm{~A}}$ receptors (Mlinar et al., 2017). Heterologous expression of 5-HT HA $_{1 \mathrm{~A}}$ receptor in HeLa cells, as well as endogenous expression of the receptor in Jurkat cells can lead to activation of G $\beta \gamma$, which stimulates PLC, leading to the production of IP3 and diacyl glycerol (DAG) (Raymond et al., 1999). Remarkably, endogenous $5-\mathrm{HT}_{1 \mathrm{~A}}$ receptors can have opposite effects on signaling 
pathways depending on where they are expressed. For example, they can activate Extracellular signal-Regulated Kinase (ERK)1/2 in the hypothalamus in a Calmodulin (CaM)-dependent manner, similar to what is observed in heterologous systems (Della Rocca et al., 1999; Turner et al., 2007), whereas they inhibit ERK1/2 phosphorylation in the hippocampus (Crane et al., 2007). In contrast, an activation of the Akt pathway has been demonstrated in the hippocampus and the medial prefrontal cortex (mPFC), where an activation of the mTOR (mammalian Target Of Rapamycin) has also been described (Cowen et al., 2005; Fukumoto et al., 2018a, 2018b). In the same brain area, activation of $5-\mathrm{HT}_{1 \mathrm{~A}}$ receptors leads to the inhibition of NMDA transmission, an effect that seems to require the Regulator of G protein signaling (RGS)4 function to be inhibited, which suggests a coupling between RGS4 and 5-HT $\mathrm{H}_{1 \mathrm{~A}}$ receptor (Figure 4A) (Gu et al., 2007). 5- $\mathrm{HT}_{1 \mathrm{~A}}$ receptor stimulation transactivates PDGF $\beta$ receptors in SH-SY5Y neuroblastoma cells and primary cortical neurons, providing a signaling link between the serotonergic system and growth factors in neurons. This transactivation pathway is Pertussis toxin-sensitive and depends on Src tyrosine kinase, PLC and intracellular $\mathrm{Ca}^{2+}$ (Kruk et al., 2013). Another source of diversity for $5-\mathrm{HT}_{1 \mathrm{~A}}$ receptor signaling comes from the difference in the pharmacology as well as the ability of the receptor to desensitize depending on its presynaptic $v s$. postsynaptic localization. $5-\mathrm{HT}_{1 \mathrm{~A}}$ receptors have also been shown to stimulate nitric oxide synthase (NOS), Nicotinamide Dinucleotide phosphate oxidase-like enzyme, and Protein Kinase C (PKC) (Adayev et al., 2003; Polter \& Li, 2010; Raymond et al., 1999).

\section{$5-\mathrm{HT}_{1 \mathrm{~B} / \mathrm{D} / \mathrm{E} / \mathrm{F}}$ receptors}

Unlike the 5-HT $1 \mathrm{~A}$ receptor that is expressed in somato-dendritic compartment, 5-HT $1 \mathrm{~B}$ receptors are preferentially located on axon terminals, where their activation potentiates serotonin reuptake (Montanez et al., 2014). Endogenous 5-HT 1 B receptors are coupled to $\mathrm{G}_{\mathrm{i} / \mathrm{o}}$ proteins, leading to the inhibition of the adenylyl cyclase pathway. This has been demonstrated first in the substantia nigra (Bouhelal et al., 1988) and then confirmed in other brain areas such as the hippocampus ( $\mathrm{Lu}$ et al., 2018). In addition, heterologous expression of the receptor showed a possible regulation of PLC and PLD, Akt, neuronal nitric oxide synthase (nNOS) and ERK1/2 (Raymond et al., 2001). 5-HT 1 в receptor stimulation also inhibits $\mathrm{Ca}^{2+}$ channels and 
activates $\mathrm{K}^{+}$channels.

Little is known about the signal transduction of other $5-\mathrm{HT}_{1}$ receptor subtypes. Studies in heterologous systems showed that they are also negatively coupled to adenylyl cyclase. The 5$\mathrm{HT}_{1 \mathrm{D}}$ receptor has recently been shown to activate an axin1- $\beta$ catenin-metalloproteinase-7 pathway, promoting tumor invasion in colorectal cancer (Sui et al., 2015). Other evidences of a role for 5- $\mathrm{HT}_{1 \mathrm{~B}}$ and $5-\mathrm{HT}_{1 \mathrm{D}}$ receptors in cancer dissemination through the regulation of matrix metalloproteinases (MMPs) have been shown. In pancreatic cancer, the knockdown of both 5$\mathrm{HT}_{1 \mathrm{~B}}$ and 5-HT $1 \mathrm{D}$ receptors using RNA interference significantly decreases cell invasion. This results from a decrease in the MMP2 and integrin/Src/FAK signaling pathway (Gurbuz et al., 2014).

\section{5-HT2A receptor}

The 5- $\mathrm{HT}_{2 \mathrm{~A}}$ receptor is canonically coupled to the $\mathrm{G} \alpha_{\mathrm{q} / 11}$ proteins and thus activates PLC (Conn $\&$ Sanders-Bush, 1984), leading to IP3 and DAG production and the activation of PKC (Figure 4B). 5- $\mathrm{HT}_{2 \mathrm{~A}}$ receptor-mediated PKC activation leads to the phosphorylation of presynaptic GluN2B-containing NMDA receptors and postsynaptic GluA2-containing AMPA receptors, to gate synaptic plasticity at thalamo-cortical synapses (Barre et al., 2016; Berthoux et al., 2018). 5- $\mathrm{HT}_{2 \mathrm{~A}}$ receptor activation by hallucinogenic agonists such as LSD, psilocybin, mescaline and 2,5-dimethoxy-4-iodoamphetamine (DOI) also leads to the activation of a $\mathrm{G \alpha}_{\mathrm{i} / \mathrm{o}}$-Src pathway in PFC neurons, whereas receptor stimulation by non-hallucinogenic agonists such as ergotamine and the anti-Parkinson agent lisuride only triggers the activation of the $\mathrm{G}_{\mathrm{q}}-\mathrm{PLC}$ pathway (Gonzalez-Maeso et al., 2007). These differences in signaling mechanisms elicited by both agonist categories leads to specific patterns of gene expression in cortical neurons: both agonist subclasses induce c-fos expression in neurons expressing 5- $\mathrm{HT}_{2 \mathrm{~A}}$ receptors, while only hallucinogens induce egr-1 and egr-2 expression (Gonzalez-Maeso et al., 2007). Intriguingly, only hallucinogenic agonists induce $5-\mathrm{HT}_{2 \mathrm{~A}}$ receptor phosphorylation at the serine residue $\left(\mathrm{Ser}^{280}\right)$ located in its third intracellular loop, an effect underlying the lower propensity of hallucinogens to promote receptor desensitization and internalization, compared with nonhallucinogenic agonists (Karaki et al., 2014). This biased phosphorylation and attenuated 
desensitization of receptor may be responsible for more sustained receptor activation by hallucinogens $v s$. non-hallucinogenic agonists that might underlie their different behavioral outcomes. Collectively, these findings suggest that hallucinogenic and non-hallucinogenic agonists induce different conformational states of the $5-\mathrm{HT}_{2 \mathrm{~A}}$ receptor and represent a striking example of functional selectivity translated into contrasting patterns of behavior (GonzalezMaeso \& Sealfon, 2009).

5- $\mathrm{HT}_{2 \mathrm{~A}}$ receptors activate several other pathways, including PLA2 (Barclay et al., 2011) and PLD (Figure 4B) (Felder et al., 1990). Interestingly, PLD activation occurs through a mechanism independent of heterotrimeric $G$ proteins that requires a physical interaction between the receptor C-terminal domain and PLD1 (Felder et al., 1990). As many GPCRs, 5$\mathrm{HT}_{2 \mathrm{~A}}$ receptor stimulation also induces activation of ERK1/2 pathway in various cell types, including neurons. Highlighting another example of functional selectivity at the 5-HT $2 \mathrm{~A}$ receptor, activation of ERK1/2 by the 5-HT precursor 5-hydroxytryptophan (5-HTP) depends on $\beta$-arrestin2, whereas DOI-elicited ERK1/2 phosphorylation is $\beta$-arrestin-independent (Schmid et al., 2008). Likewise, 5-HTP but not $N$-methyltryptamines induces Akt stimulation through a $\beta$-arrestin2-dependent mechanism (Schmid \& Bohn, 2010). Furthermore, the hallucinogenic-like effects, e.g. the head twitch response, induced by 5-HTP is $\beta$-arrestindependent, whereas DOI or $N$-methyltryptamines elicit similar behavioral responses in wild type and $\beta$-arrestin2 knockout mice (Schmid \& Bohn, 2010; Schmid et al., 2008). $\beta$-arrestindependent ERK1/2 activation has also been involved in the counteractive effect of 5-HT2A receptors on 5- $\mathrm{HT}_{1 \mathrm{~A}}$ receptor-operated inhibition of NMDA receptor currents in PFC pyramidal neurons, providing one molecular substrate for the complex interactions between prefrontal serotonergic and NMDA receptors that underlie cognitive and emotional control by these systems (Yuen et al., 2008). Transactivation of growth factor receptors has also been involved in 5- $\mathrm{HT}_{2 \mathrm{~A}}$ receptor-mediated ERK1/2 phosphorylation (Quinn et al., 2002; Tsuchioka et al., 2008). In rat C6 glioma cells, it depends on FGFR2 receptor transactivation and leads to the release of glial cell line-derived neurotrophic factor (Figure 4B) (Tsuchioka et al., 2008). In smooth muscle cells, 5- $\mathrm{HT}_{2 \mathrm{~A}}$ receptor-mediated ERK1/2 activation is PLC/PKC-dependent and 
ultimately results in MMP-13 production. This activation could be crucial for the collagen removal required post-partum to restore uterus reproductive function (Shum et al., 2002).

$5-\mathrm{HT}_{2 \mathrm{~A}}$ receptors engage the Janus Kinase-2 (JAK)2/Signal transducers and activators of transcription (STAT)3 pathway in various cell types (Figure 4B). In trophoblast choricarcinoma cells, 5-HT2A receptor stimulation activates both JAK2/STAT3 and MEK1/2-ERK1/2 pathways, which results in an increased DNA synthesis and improved viability of the cells (Oufkir et al., 2010; Oufkir \& Vaillancourt, 2011). Activation of the JAK2/STAT3 pathway has also been demonstrated in rat frontal cortex, where it leads to the extinction of receptorstimulated PLC activation (Singh et al., 2010).

Finally, 5- $\mathrm{HT}_{2 \mathrm{~A}}$ (and 5- $\mathrm{HT}_{2 \mathrm{C}}$ ) receptor stimulation by DOI induces transglutaminase (TGase)catalyzed transamidation and activation of the small G proteins $\operatorname{Rac} 1$ and $\mathrm{Cdc} 42$ in primary cultured cortical neurons (Figure 4B), a process that causes a transient dendritic spine enlargement (Mi et al., 2017).

\section{5-HT2B receptor}

The 5- $\mathrm{HT}_{2 \mathrm{~B}}$ receptor is also coupled to the $\mathrm{G}_{\mathrm{q} / 11}$ proteins and activates PLC. 5-HT2B receptor stimulation in mouse fibroblasts induces ERK1/2 activation through transactivation of the platelet-derived growth factor (PDGF) receptor to promote cyclin D1 expression. Moreover, 5$\mathrm{HT}_{2 \mathrm{~B}}$ receptor stimulation increases activity of the Src family kinases, c-Src, Fyn, and c-Yes but only Src contributes to Cyclin D1 expression and cell cycle control by the receptor (Nebigil et al., 2000). In astroglial cells, activation of the receptor induced by fluoxetine treatment triggers ERK1/2 phosphorylation that depends on EGF receptor transactivation (Li et al., 2008). Furthermore, 5- $\mathrm{HT}_{2 \mathrm{~B}}$ receptors are coupled to PLA2 (Tournois et al., 1998) and can activate both constitutive and inducible NOS (Manivet et al., 2000; Tournois et al., 1998).

\section{5-HT $2 \mathrm{C}$ receptor}

Both non-edited and edited forms of the $5-\mathrm{HT}_{2 \mathrm{C}}$ receptor are coupled to $\mathrm{G}_{\mathrm{q} / 11}$ proteins and activate PLC (Figure 4), but the editing results in decreased constitutive activity of the receptor and reduced agonist affinity and potency (Herrick-Davis et al., 1999; Niswender et al., 1999). 
5- $\mathrm{HT}_{2 \mathrm{C}}$ receptor stimulation also induces PLD activation via coupling to $\mathrm{G}_{13}$ protein, and the transactivation of the small G-protein RhoA (Figure 4C) (McGrew et al., 2004). Notably, the fully edited (5HT $2 \mathrm{C}-\mathrm{VGV})$ receptor does not activate the PLD pathway (McGrew et al., 2004), further supporting that editing represent a key regulatory mechanism of 5- $\mathrm{HT}_{2 \mathrm{C}}$ receptoroperated signaling. Agonist-dependent and independent 5- $\mathrm{HT}_{2 \mathrm{C}}$ receptor activation also leads to ERK1/2 phosphorylation through a G-independent, $\beta$-arrestin-dependent mechanism, which requires the receptor to be bound to CaM (Figure 4C) (Labasque et al., 2010; Labasque et al., 2008). Recent studies revealed that the $\beta$-arrestin-dependent stimulation of ERK $1 / 2$ pathway by the $5-\mathrm{HT}_{2 \mathrm{C}}$ receptor, as well as other GPCRs that engage ERK signaling through a $\beta$-arrestindependent mechanism, requires $\beta$-arrestin2 phosphorylation on $\mathrm{Thr}^{383}$ (Cassier et al., 2017). Finally, stimulation of $5-\mathrm{HT}_{2 \mathrm{C}}$ receptors induces the transamidation of the small $\mathrm{G}$ proteins Rac1 and Cdc42 in primary cortical cultures (Mi et al., 2017).

\section{$5-\mathrm{HT}_{3}$ receptors}

As cationic channels permeable to $\mathrm{Na}^{+}, \mathrm{K}^{+}$and $\mathrm{Ca}^{2+}, 5-\mathrm{HT}_{3}$ receptors give rise to fast, depolarizing responses and $\mathrm{Ca}^{2+}$ increase through voltage-sensitive $\mathrm{Ca}^{2+}$ channels in neurons upon activation (Maricq et al., 1991). Postsynaptic receptors mediate fast synaptic transmission while presynaptic receptors promote the release of 5-HT or other neurotransmitters in various brain regions.

\section{5-HT 4 receptor}

Stimulation of native $5-\mathrm{HT}_{4}$ receptors activates the $\mathrm{G}_{\mathrm{s}} / \mathrm{cAMP} / \mathrm{PKA}$ pathway in colliculi neurons, guinea-pig hippocampus and nucleus accumbens (Figure 4D) (Bockaert et al., 1990; Dumuis et al., 1988; Dumuis et al., 1989). Coupling to other $G$ proteins such as $G_{q}$ and $G_{i / o}$ have also been described in heterologous systems (Bockaert et al., 2006; Ponimaskin et al., 2002). 5-HT 4 receptors are also coupled to $\mathrm{G \alpha}_{13}$ (Figure 4D), an effect that leads to a RhoAdependent neurite retraction and cell rounding in NIE-115 cells (Ponimaskin et al., 2002). Further supporting a prominent role of $5-\mathrm{HT}_{4}$ receptors in the regulation of neuronal architecture, receptor coupling to $\mathrm{G}_{13}$ in cultured hippocampal neurons results in the reduction of neurite length and of the total number of neurites (Kvachnina et al., 2005). Notably, splice 
variants of the receptor not only exhibit variable levels of constitutive activity (Claeysen et al., 1999) but can also display specificity towards the G protein with which they are coupled. For example, the 5- $\mathrm{HT}_{4(\mathrm{~b})}$ receptor activates both $\mathrm{G}_{\mathrm{s}}$ and $\mathrm{G}_{\mathrm{i} / \mathrm{o}}$ proteins, whereas the 5- $\mathrm{HT}_{4(\mathrm{a})}$ receptor is only coupled to $\mathrm{G}_{\mathrm{s}}$ (Pindon et al., 2002). The 5-HT4 receptor also engages the ERK1/2 pathway through a $\beta$-arrestin-independent mechanism that requires Src activation (Figure 4D) (Barthet et al., 2009), consistent with the inability of the receptor to promote $\beta$-arrestin2 phosphorylation at $\mathrm{Thr}^{383}$ (Cassier et al., 2017). Activation of 5-HT4 receptors also induces activation of the exchange factor Epac (Figure 4D), which in turn stimulates Rac and $\alpha$ secretase-mediated amyloid precursor protein (APP) processing. This results in the release of the neuroprotective extracellular APP fragment sAPP $\alpha$ from both $\mathrm{CHO}$ cells and primary cultured cortical neurons (Maillet et al., 2003). More recently, an interaction between the 5-HT 4 receptor and the $\alpha$-secretase ADAM10 has been described (Cochet et al., 2013). This interaction results in an increase in $\mathrm{sAPP} \alpha$ release through the PKA/Epac signaling pathway (Cochet et al., 2013).

\section{$5-\mathrm{HT}_{5 \mathrm{~A}}$ receptor}

Amongst the two 5- $\mathrm{HT}_{5}$ receptor variants identified, only the 5- $\mathrm{HT}_{5 \mathrm{~A}}$ variant is functional in humans (Grailhe et al., 2001). The 5- $\mathrm{HT}_{5 \mathrm{~A}}$ receptor is coupled to $\mathrm{G}_{\mathrm{i} / \mathrm{o}}$ proteins and inhibits cAMP production in recombinant cells, but little is known about the coupling of native receptors (Noda et al., 2003). In the cerebral cortex of rodents, 5-HT5 receptor stimulation induces an inward rectifying outward current that is suppressed by blockers of Kir3 channels (Goodfellow et al., 2012). The 5- $\mathrm{HT}_{5}$ receptor has been involved in pain (Munoz-Islas et al., 2014), cognitive deficits in a rat model of schizophrenia (Avila-Rojas et al., 2015; Nikiforuk et al., 2016) and in the acoustic startle circuits (Curtin et al., 2013).

\section{$5-\mathrm{HT}_{6}$ receptor}

As firstly established in mouse striatal neurons in primary culture (Sebben et al., 1994), the 5$\mathrm{HT}_{6}$ receptor is canonically coupled to $\mathrm{G}_{\mathrm{s}}$ protein and activates adenylyl cyclase (Figure 4E) (Sebben et al., 1994). In striatal neurons, 5- $\mathrm{HT}_{6}$ receptor-operated cAMP signaling can regulate DARPP32 enzymatic activity (Svenningsson et al., 2002). The 5-HT 6 receptor binds to and 
activates the tyrosine kinase Fyn, a process that leads to ERK1/2 phosphorylation (Figure 4E) (Yun et al., 2007). 5- $\mathrm{HT}_{6}$ receptor activation also induces the translocation of Jun activation domain-binding protein-1 (Jab1) into the nucleus, leading to an increase in c-Jun phosphorylation and the interaction between Jab1 and c-Jun (Yun et al., 2010). The 5-HT6 receptor can also activate the mTOR pathway in various brain regions, including the prefrontal cortex (Figure 4E). mTOR activation under the control of 5-HT 6 receptors, has been involved in both cognitive deficits observed in rodent developmental models of schizophrenia (Meffre et al., 2012) and seizure activity in epilepsy (L. Wang et al., 2015). Finally, 5- $\mathrm{HT}_{6}$ receptors activate Cyclin-dependent kinase $(\mathrm{Cdk}) 5$ in an agonist-independent manner through a mechanism involving a reciprocal interplay between the receptor and Cdk5 whereby phosphorylation of receptor $\mathrm{Ser}^{350}$ by associated Cdk5 is required for 5- $\mathrm{HT}_{6}$ receptor-operated Cdk5 activation (Figure 4E). Cdk5 in turn activates a Cdc42 pathway, leading to neuronal differentiation and the initiation of neurite growth (Duhr et al., 2014). 5-HT6 receptor-elicited Cdk5 signaling has also been involved in the fine-tuning of neuronal migration by the receptor (Jacobshagen et al., 2014).

\section{$5-\mathrm{HT}_{7}$ receptor}

$5-\mathrm{HT}_{7}$ receptors are positively coupled to adenylyl cyclase via $\mathrm{G} \alpha_{\mathrm{s}}$ and induce cAMP production (Figure 4F) (Bard et al., 1993; Lovenberg et al., 1993; Ruat, Traiffort, Leurs, et al., 1993). They are also coupled to $\alpha_{12}$ (Kvachnina et al., 2005) in NIH/3T3 cells and hippocampal neurons, where their stimulation leads to the activation of RhoA and Cdc42, and triggers neurite growth (Kvachnina et al., 2005). Both agonist-dependent and independent activation of $5-\mathrm{HT}_{7}$ receptors induce formation of dendritic spines and synaptogenesis in cortical and striatal neurons through the activation of Cdk5 and Cdc42 (Figure 4F) (Speranza et al., 2017). Likewise, activation of $5-\mathrm{HT}_{7} / \mathrm{G}_{12}$ signaling potentiates formation of dendritic spines and enhances synaptic activity in hippocampal neurons at early post-natal stages. In a recent study, Bijata et al. demonstrated that the effects of the 5- $\mathrm{HT}_{7}$ receptor upon dendritic spine morphogenesis and synaptic plasticity depend on local activation of MMP-9 that in turn cleaves CD44 bound to the receptor, leading to Cdc42 activation (Bijata et al., 2017). In 
hippocampal neurons, the 5- $\mathrm{HT}_{7}$ receptor also activates ERK1/2 (Errico et al., 2001), but the underlying mechanism is not fully understood. It may involve PKA-dependent phosphorylation of the guanine nucleotide exchange factor Ras-GRF1 and subsequent Ras activation (Norum et al., 2003; Norum et al., 2005).

\section{VI- Homo and heterodimerization of 5-HT receptors and their consequences on 5-HT receptor signaling and functions}

Accumulating evidence indicates that GPCRs are not only monomeric entities that couple to G proteins upon activation by a single ligand molecule, but that they form dimers or even higher order oligomers composed of unique or different receptor proteins, which exhibit specific pharmacological and signaling properties underlying unique physiological outcomes. It is thus not surprising that the ability to form dimers, and in some cases oligomers, has now been shown for many 5-HT receptors, including 5-HT $1 \mathrm{~A}$ (Kobe et al., 2008), 5-HT $2 \mathrm{~A}$ (Brea et al., 2009; Teitler \& Klein, 2012), 5-HT $2 \mathrm{C}$ (Herrick-Davis et al., 2015), 5-HT 4 (Pellissier et al., 2011), and 5-HT 7 (Teitler \& Klein, 2012) receptors. Different factors regulate 5-HT receptor oligomerization. These include receptor density, with low expression levels favoring monomeric forms while higher expression levels favor association of dimers into tetramers, cholesterol level in the membrane and ligand binding. For instance, if 5-HT $\mathrm{H}_{1 \mathrm{~A}}$ receptors have the propensity to form homodimers in absence of ligand, agonists (8-OH-DPAT) enhance while antagonists (SCH58216 and methysergide) decrease dimer formation (Lukasiewicz et al., 2007). Homodimer formation not only leads to new pharmacological entities with specific binding and signal transduction properties but it might also be important for receptor trafficking to the membrane when it occurs early during receptor synthesis, as shown for the $5-\mathrm{HT}_{2} \mathrm{C}$ receptor (Herrick-Davis et al., 2006).

Certain 5-HT receptors are not only capable of forming homodimers, or homo-oligomers, but can also form heteromers with different 5-HT receptor subtypes (Table 1). Due to technical difficulties, their ability to form heteromers has mostly been demonstrated in vitro using cell lines and in most cases remains to be established in vivo. However, evidence of the presence of heteromers composed of different 5-HT receptor subtypes in vivo is emerging. For instance, 5- 
$\mathrm{HT}_{2 \mathrm{~A}}$ and 5- $\mathrm{HT}_{2 \mathrm{C}}$ receptors were found to form a complex that might be involved in the control of impulsivity in the rat mPFC (Anastasio et al., 2015), and the ability of both receptors to heteromerize was recently confirmed by three complementary biophysical techniques (Felsing et al., 2018). 5- $\mathrm{HT}_{2 \mathrm{~B}}$ receptors also form heteromers with 5- $\mathrm{HT}_{2 \mathrm{C}}$ receptors. Heteromerization with $5-\mathrm{HT}_{2 \mathrm{C}}$ receptors blunts both $5-\mathrm{HT}_{2 \mathrm{~A}}$ and $5-\mathrm{HT}_{2 \mathrm{~B}}$ receptor-operated signaling in transfected cells and neurons, suggesting that $5-\mathrm{HT}_{2}$ receptors form functionally asymmetric heterodimers in vitro and in vivo (Moutkine et al., 2017). Co-immunoprecipitation studies suggest that the $5-\mathrm{HT}_{1 \mathrm{~A}}$ receptor forms hetero-oligomers with several 5-HT receptor subtypes, but only heteromers with $5-\mathrm{HT}_{2 \mathrm{~A}}$ or $5-\mathrm{HT}_{7}$ receptors have been validated. The existence of 5$\mathrm{HT}_{1 \mathrm{~A}}: 5-\mathrm{HT}_{2 \mathrm{~A}}$ receptor heteromers has been demonstrated in the pyramidal cell layer of CA1CA3 regions of the dorsal hippocampus using in situ proximity ligation assay and was further validated in cellular models by BRET (Borroto-Escuela et al., 2017). The number of 5-HT $1 \mathrm{~A}: 5-$ $\mathrm{HT}_{2 \mathrm{~A}}$ clusters in CA1 and CA2 regions decreases $24 \mathrm{~h}$ after a forced swim test session, suggesting that $5-\mathrm{HT}_{1 \mathrm{~A}}: 5-\mathrm{HT}_{2 \mathrm{~A}}$ heteromerization is a dynamic process that might be involved in depression-like behavior (Borroto-Escuela et al., 2017). 5- $\mathrm{HT}_{1 \mathrm{~A}}: 5-\mathrm{HT}_{7}$ receptor heteromerization inhibits $5-\mathrm{HT}_{1 \mathrm{~A}}$ receptor-mediated activation of $\mathrm{G}_{\mathrm{i}}$ without affecting $5-\mathrm{HT}_{7}$ receptor-operated signaling, and decreases the ability of the 5-HT $1 \mathrm{~A}$ receptor to activate GIRK channels in hippocampal neurons (Renner et al., 2012). Moreover, 5-HT ${ }_{1 \mathrm{~A}}: 5-\mathrm{HT}_{7}$ heteromerization promotes 5 -HT-induced $5-\mathrm{HT}_{1 \mathrm{~A}}$ receptor internalization and receptoroperated ERK1,2 activation.

Accumulated evidence also indicates that 5-HT receptors can form heteromers with GPCRs not activated by 5 -HT, with important consequences on their signaling and functional outcomes (Table 1). 5-HT $1 \mathrm{~A}$ receptors heteromerize with galanin receptor 1 (GalR1) (Borroto-Escuela, Narvaez, et al., 2010), the zinc receptor GPR39 (Tena-Campos et al., 2015), $\mathrm{D}_{2}$ dopaminergic receptor (Lukasiewicz et al., 2016) and $\mu$-opioid receptor (MOR) (Cussac et al., 2012). GalR15-HT $\mathrm{H}_{1 \mathrm{~A}}$ receptor heteromerization induces a reciprocal inhibition of signaling engaged by both receptors via allosteric mechanisms (Borroto-Escuela, Narvaez, et al., 2010). Intriguingly, GalR1-5-HT 1 A receptor heteromers can further associate with GPR39 to form heterotrimers and 
the presence of GalR 1 seems to inhibit both 5-HT $1 \mathrm{~A}$ and GPR39-operated signaling (TenaCampos et al., 2015). Likewise, 5- $\mathrm{H}_{1 \mathrm{~A}}: \mathrm{D}_{2}$ heteromer formation seems to profoundly affect signal transduction properties of both receptors and the response to antipsychotics (Lukasiewicz et al., 2016). Though the existence 5-HT $\mathrm{HT}_{1 \mathrm{~A}}: \mathrm{D}_{2}$ heteromers has been established in mouse prefrontal cortex (Kolasa et al., 2018), the irrefutable proof that the observed effects of heteromerization on signal transduction of both receptors result from heteromer formation and not solely receptor co-expression is still lacking. The existence of MOR:5-HT $1 \mathrm{~A}$ heteromers in vivo also remains to be established. Data obtained in cell lines suggest a crosstalk within MOR:5-HT ${ }_{1 \mathrm{~A}}$ heteromers to activate $\mathrm{G} \alpha_{\mathrm{o}}$ and ERK1/12 pathways (Cussac et al., 2012).

The 5- $\mathrm{HT}_{2 \mathrm{~A}}$ receptor forms heteromers with a number of GPCRs, including mGlu 2 (GonzalezMaeso et al., 2008), cannabinoid $\mathrm{CB}_{1}$ (Vinals et al., 2015), $\mathrm{D}_{2}$ (Borroto-Escuela, RomeroFernandez, et al., 2010) and cortiocotropin releasing factor $(\mathrm{CRF})_{1}$ receptors (Narla et al., 2015), the latter involving PDZ-based interactions. Evidence of their existence in vivo has only been established for 5-HT2A:mGlu 2 (Gonzalez-Maeso et al., 2008) and 5- $\mathrm{HT}_{2 \mathrm{~A}}: \mathrm{CB}_{1}$ heteromers (Vinals et al., 2015). 5- $\mathrm{HT}_{2 \mathrm{~A}}: \mathrm{mGlu}_{2}$ heteromerization strongly influences signal transduction elicited by both receptors by modulating their coupling to $G$ proteins and phosphorylation profile (Fribourg et al., 2011; Murat et al., 2018). Numerous data also suggest that 5$\mathrm{HT}_{2 \mathrm{~A}}: \mathrm{mGlu}_{2}$ heteromers represent the actual receptor entity that underlies the psychomimetic effects of hallucinogens as well as the action of second and last-generation antipsychotics that acts at 5- $\mathrm{HT}_{2 \mathrm{~A}}$ and $\mathrm{mGlu}_{2}$ receptors, respectively (Benvenga et al., 2018; Delille et al., 2013; Fribourg et al., 2011; Moreno et al., 2011). 5-HT2A: $\mathrm{CB}_{1}$ heteromer formation switches G protein coupling of 5- $\mathrm{HT}_{2 \mathrm{~A}}$ receptor from $\mathrm{G}_{\mathrm{q}}$ to $\mathrm{G}_{\mathrm{i}}$ (Vinals et al., 2015). 5- $\mathrm{HT}_{2 \mathrm{~A}}: \mathrm{CB}_{1}$ heteromers also mediate $\Delta$-9-tetrahydrocannabinol (THC)-induced memory impairment but not its analgesic effects, suggesting that they might be relevant targets to dissociate the beneficial antinociceptive properties of THC from its side effects upon cognition (Vinals et al., 2015). Functional crosstalk within $5-\mathrm{HT}_{2 \mathrm{~A}}-\mathrm{D}_{2}$ and $5-\mathrm{HT}_{2 \mathrm{~A}} / \mathrm{CRF}_{1}$ receptor heteromers has also been suggested (Borroto-Escuela, Romero-Fernandez, et al., 2010; Narla et al., 2015).

The 5-HT2 receptor forms functional heteromers with $\mathrm{MT}_{2}$ melatonin receptors in human 
cortex and hippocampus that may be of special interest as target for the treatment of mood disorders in light of the "synergistic" melatonin agonist/5- $\mathrm{HT}_{2 \mathrm{C}}$ antagonist profile of the antidepressant agomelatine (Kamal et al., 2015). The 5- $\mathrm{HT}_{2 \mathrm{C}}$ receptor also forms complexes with another receptor involved in the control of food intake, the ghrelin GHS-R1a receptor (Schellekens et al., 2015). Blocking 5- $\mathrm{HT}_{2 \mathrm{C}}$ receptor signaling potentiates ghrelin orexigenic effect, whereas lorcaserin, a 5- $\mathrm{HT}_{2 \mathrm{C}}$ receptor agonist approved for the treatment of obesity, attenuates ghrelin-induced food intake (Schellekens et al., 2015). The role of heteromerization in these effects remains to be established.

\section{VII- 5-HT receptor-interacting proteins and their role in 5-HT receptor-operated signal transduction and functions}

Over the past 20 years, it has become evident that GPCRs, including G protein-coupled 5-HT receptors, are not solely capable of interacting with other GPCRs, G proteins and $\beta$-arrestins, but that they additionally recruit specific proteins called GIPs (GPCR-interacting proteins) that strongly influence GPCR intracellular fate and signal transduction properties (Bockaert et al., 2004). Some 5-HT receptors are certainly amongst the GPCRs for which the largest number of interacting proteins has been characterized, mostly thanks to two-hybrid screens or affinity purification coupled to mass spectrometry (AP-MS) proteomic strategies (Marin et al., 2012). However, the characterization of 5-HT receptor interactomes differs from one receptor to another and still remains to be done for several 5-HT receptors (Table 2).

\section{$5-\mathrm{HT}_{1 \mathrm{~A}}$ receptor}

$\mathrm{CaM}$ was the first interacting partner of the $5-\mathrm{HT}_{1 \mathrm{~A}}$ receptor identified. $\mathrm{CaM}$ is recruited via two binding motifs located in the receptor i3 loop and thereby interferes with receptor phosphorylation by PKC and desensitization (Turner et al., 2004). The 5-HT $\mathrm{HA}_{1 \mathrm{~A}}$ receptor also binds to Yif1B, the orthologue of the yeast Yiflp implicated in vesicular trafficking between the endoplasmic reticulum and the Golgi apparatus, via its C-terminal domain (Carrel et al., 2008). Yif1B functions as a scaffold protein that recruits a complex composed of Yip1A, Rab6, Kif5B and dynein, involved in dendritic targeting of the receptor (Al Awabdh et al., 2012). 


\section{$5-\mathrm{HT}_{1 \mathrm{~B}}$ receptor}

The 5-HT $1 \mathrm{~B}$ receptor interacts with the adaptor protein $\mathrm{p} 11$, also designated as S100A10, which has been involved in depression-like behaviors and responses to antidepressants as well as to cocaine in rodents. $\mathrm{P} 11$ increases localization of $5-\mathrm{HT}_{1 \mathrm{~B}}$ receptors at the cell surface and data suggest that $5-\mathrm{HT}_{1 \mathrm{~B}}$ receptor:p11 interaction may play a role in response to antidepressants (Svenningsson et al., 2006). Further studies suggested a role of this interaction in L-DOPA treatment of Parkinson's disease (Zhang et al., 2008) and the regulation of emotional memory by $5-\mathrm{HT}_{1 \mathrm{~B}}$ receptors (Eriksson et al., 2013).

\section{$5-\mathrm{HT}_{2 \mathrm{~A}}$ receptor}

The 5- $\mathrm{HT}_{2 \mathrm{~A}}$ receptor recruits several $\mathrm{PDZ}$ domain-containing proteins (PDZ proteins) through its C-terminal PDZ-binding motif (-SCV). These include the major postsynaptic protein PSD95 and other proteins of the postsynaptic density (Becamel et al., 2004), which profoundly influence receptor trafficking and signaling. 5- $\mathrm{HT}_{2 \mathrm{~A}}$ receptor:PSD95 interaction modulates receptor targeting (Xia, Hufeisen, et al., 2003), trafficking (Xia, Gray, et al., 2003), psychomimetic effects of hallucinogens and responses to antipsychotics acting on $5-\mathrm{HT}_{2 \mathrm{~A}}$ receptors (Abbas et al., 2009) as well as neuropathic pain (Pichon et al., 2010; Vogrig et al., 2013). The 5-HT2A receptor also binds to PDZK1/NHERF3 but, surprisingly, through a PDZindependent mechanism. 5- $\mathrm{HT}_{2 \mathrm{~A}}$ receptor/PDZK1 association negatively regulates $5-\mathrm{HT}_{2 \mathrm{~A}}$ receptor endocytosis and, correspondingly, promote receptor-operated PLC activation (Walther et al., 2015). Likewise, 5- $\mathrm{HT}_{2 \mathrm{~A}}$ receptor association with SAP97 decreases receptor internalization rate and enhance receptor-induced inositol phosphate production (Dunn et al., 2014). More recently, using a PDZ overlay assay, Hammad et al. showed that 5- $\mathrm{HT}_{2 \mathrm{~A}}$ receptors physically interact with the three members of the MAGI PDZ protein family (MAGI-1, MAGI2 and MAGI-3) (Hammad et al., 2018). All three proteins share a similar structure containing one guanylate kinase-like (GK) domain, two tryptophan (WW) domains and six PDZ domains. MAGI proteins promote $5-\mathrm{HT}_{2 \mathrm{~A}}$ receptor internalization and differentially modulate receptorinduced signaling pathways: their association with the receptor enhances the recruitment of 
PLC 33 to the receptor and PLC signaling, whereas it inhibits ERK1/2 activation, the latter effect being PDZ-independent (Hammad et al., 2018).

The 5- $\mathrm{HT}_{2 \mathrm{~A}}$ receptor also recruits a number of non-PDZ proteins that influence their signal transduction and functions. As shown for 5- $\mathrm{HT}_{1 \mathrm{~A}}$ receptors, 5- $\mathrm{HT}_{2 \mathrm{~A}}$ receptors bind to CaM, which influences receptor phosphorylation and desensitization (Turner \& Raymond, 2005). They also associate with p90 ribosomal S6 kinase (RSK)2, a downstream kinase of the ERK1,2 pathway that phosphorylates a serine residue located in the receptor i3 loop (Sheffler et al., 2006). Notably, RSK2 expresses a C-terminal PDZ binding motif and RSK2/PDZ protein interactions have been demonstrated to be important for the role of RSK2 in regulation of synaptic transmission (G. M. Thomas et al., 2005). 5-HT2A receptors associate with caveolin-1 in various cell types (Bhatnagar et al., 2004). Both form a complex with KV1.5 channels upon receptor stimulation by 5-HT (Cogolludo et al., 2006). Finally, 5- $\mathrm{HT}_{2 \mathrm{~A}}$ receptors associate with PLD1 (Felder et al., 1990) and the ADP-ribosylation factors ARF1 and, to a lesser extent, ARF6 (Robertson et al., 2003). Physical interaction between PLD1 and ARF proteins seems to be essential for 5- $\mathrm{HT}_{2 \mathrm{~A}}$ receptor-operated PLD activation.

\section{5-HT 2 B receptor}

The 5- $\mathrm{HT}_{2 \mathrm{~B}}$ receptor interactome remains much less characterized, when compared to the 5$\mathrm{HT}_{2 \mathrm{~A}}$ receptor one. The presence of a PDZ binding motif at its C-terminus suggests its interaction with $\mathrm{PDZ}$ proteins. As 5- $\mathrm{HT}_{2 \mathrm{~A}}$ and 5- $\mathrm{HT}_{2 \mathrm{C}}$ receptors, the 5- $\mathrm{HT}_{2 \mathrm{~B}}$ receptor recruits the multi-PDZ protein 1 (MUPP1) (Becamel et al., 2001), but the role of this interaction remains to be elucidated. It has been shown that the activation of NOS by the $5-\mathrm{HT}_{2 \mathrm{~B}}$ receptor is PDZdependent (Manivet et al., 2000), but the nature of the PDZ protein(s) involved also remains to be established.

\section{5-HT $2 \mathrm{C}$ receptor}

In line with the presence of PDZ binding motif at its C-terminal extremity, the 5- $\mathrm{HT}_{2 \mathrm{C}}$ recruits a number of PDZ proteins through PDZ-based interactions. MUPP1 was the first receptor PDZ binding partner identified (Ullmer et al., 1998). Further studies showed that 5-HT2C 
receptor:MUPP1 interaction is dynamically regulated by agonist-dependent receptor phosphorylation at a serine residue located in the PDZ binding motif $\left(\mathrm{Ser}^{458}\right)$ (Parker et al., 2003). Association of the 5-HT2 like Caenorhabditis elegans receptor SER-1 with a multi-PDZ domain containing protein similar to MUPP1 is involved in 5-HT-stimulated egg laying in the worm (Xiao et al., 2006), suggesting that this interaction play a key in some receptor functions. The receptor also binds to additional PDZ proteins, such as PSD-95 and MPP3, which differentially regulate receptor trafficking (Becamel et al., 2002; Gavarini et al., 2006). As previously mentioned, interaction of $\mathrm{CaM}$ with the juxta-membrane region of the receptor $\mathrm{C}$ terminus is critical for the G-independent, $\beta$-arrestin-dependent, activation of ERK $1 / 2$ by the receptor (Labasque et al., 2008). The interaction of PTEN (phosphatase and tensin homolog deleted on chromosome 10) with the receptor i3 loop leads to inhibition of agonist-induced receptor phosphorylation. Disruption of $5-\mathrm{HT}_{2 \mathrm{C}}$ receptor/PTEN interaction prevents the increase in firing rate of ventral tegmental area dopaminergic neurons induced by THC, thus mimicking the effect of agonist receptor stimulation (Ji et al., 2006). More recently, Kleene et al. showed an interaction between the receptor i3 loop and the cell adhesion molecule close homolog of L1 (CHL1) and that CHL1 regulates receptor association with $\beta$-arrestin and PTEN and signaling pathways engaged by constitutively active 5- $\mathrm{HT}_{2 \mathrm{C}}$ receptors (Kleene et al., 2015). Finally, 5-HT $2 \mathrm{C}$ receptors expressed in hypothalamus interact with Abelson helper integration site 1 (Ahi1) protein. This interaction promotes $5-\mathrm{HT}_{2 \mathrm{C}}$ receptor degradation in the lysosomal pathway and thereby contributes to its control of food intake (H. Wang et al., 2012).

\section{$5-\mathrm{HT}_{4}$ receptor}

Consistent with the presence of a PDZ binding motif at the C-terminus of some 5- $\mathrm{HT}_{4}$ receptor variants (e.g. SCF and VPV in 5- $\mathrm{HT}_{4 \mathrm{a}}$ and 5- $\mathrm{HT}_{4 \mathrm{e}}$ variants, respectively), these variants recruit specific sets of PDZ proteins (Joubert et al., 2004). For instance, the 5-HT $\mathrm{H}_{4}$ receptor interacts with sortin nexin (SNX)27 and NEHRF1 (EBP50), that target the receptor to microvilli where it is co-localized with activated ezrin, and early endosomes, respectively (Joubert et al., 2004). Further studies identified SNX27 as an essential adaptor protein linking GPCRs to the retromer and contributing to their endosome-to-plasma membrane traffic (Temkin et al., 2011). The 
function of other 5- $\mathrm{HT}_{4}$ receptor-PDZ protein interactions identified remains to be elucidated. The 5- $\mathrm{HT}_{4}$ receptor directly interacts with $\mathrm{Src}$ and its activation promotes auto-phosphorylation of Src bound to the receptor at $\mathrm{Tyr}^{416}$. Src association with the receptor and its subsequent phosphorylation are required for the engagement of ERK1/2 signaling by the $5-\mathrm{HT}_{4}$ receptor (Barthet et al., 2009). Reminiscent of the 5- $\mathrm{HT}_{1 \mathrm{~B}}$ receptor, the 5- $\mathrm{HT}_{4}$ receptor interacts with p11 (Warner-Schmidt et al., 2009). P11 increases 5-HT 4 receptor surface expression, thereby enhancing receptor-operated signaling, and is required for the behavioral antidepressant response induced by $5-\mathrm{HT}_{4}$ receptor stimulation (Warner-Schmidt et al., 2009). Likewise, induction of $\mathrm{p} 11$ expression by BDNF or imipramine in cardiomyocytes reveals $5-\mathrm{HT}_{4}$ receptormediated effects on $\mathrm{Ca}^{2+}$ handling (Meschin et al., 2015). The 5- $\mathrm{HT}_{4}$ receptor also physically associates with the $\alpha$-secretase ADAM10 and Amyloid Precursor Protein (APP) to promote its non-amyloidogenic cleavage and the release of the neuroprotective soluble APP fragment sAPP $\alpha$ in an agonist-independent manner (Cochet et al., 2013). More recently, a systematic screen of protein-protein interactions implicating clinically relevant GPCRs identified G protein-regulated inducer of neurite outgrowth 2 (GPRIN2) (Sokolina et al., 2017), a protein known to interact with G proteins (Chen et al., 1999) and the Parkinson's disease-associated receptor GPR37 (Dusonchet et al., 2009), as novel 5-HT4d receptor interacting partners (Sokolina et al., 2017). Co-expression of GPR37 and GPRIN2 with the 5-HT4d receptor potentiates receptor-elicited cAMP production while it prevents ERK1/2 phosphorylation in HEK-293 cells (Sokolina et al., 2017).

\section{$5-\mathrm{HT}_{6}$ receptor}

The Src family tyrosine kinase Fyn was the first 5- $\mathrm{HT}_{6}$ receptor interacting protein identified by means of a two-hybrid screen using the receptor C-terminal domain as bait (Yun et al., 2007). Further studies showed that $5-\mathrm{HT}_{6}$ receptor:Fyn interaction promotes receptor cell surface expression and its coupling to $\mathrm{G}$ proteins and, reciprocally, that 5 - $\mathrm{HT}_{6}$ receptor activation increases Fyn kinase activity (Yun et al., 2007). Furthermore, activation of ERK1/2 signaling depends on Fyn (Yun et al., 2007). The same group of investigators identified two additional 5- $\mathrm{HT}_{6}$ receptor partners, namely, Jun activation domain-binding protein1 (Jab1) (Yun et al., 
2010) and the microtubule-associated protein Map1b (Kim et al., 2014). 5-HT6 receptor stimulation promotes Jab1 translocation to the nucleus, its association with c-Jun, and c-Jun phosphorylation (Yun et al., 2010). Both Jab1 and Map1b increase 5-HT6 receptor cell surface expression and consequently receptor-mediated signal transduction (Kim et al., 2014; Yun et al., 2010).

An AP-MS proteomic strategy revealed that 5- $\mathrm{HT}_{6}$ receptors recruit several proteins of the mTOR pathway (Meffre et al., 2012). These include mTOR itself and raptor, which, together with mTOR, constitutes the mTOR complex 1 (mTORC1), Ttil and Tel2, which form a complex required for the assembly and stability of mTORC1, neurofibromin1 (NF1), a Ras GTPase activating protein identified as an upstream modulator of the mTOR pathway (Johannessen et al., 2005) and Vps34, a class III phosphatidylinositol 3-kinase (PI3K) necessary for $\mathrm{mTORC1}$ activation in response to amino acids and implicated in autophagosome formation (Backer, 2008). Physical interaction between the 5-HT6 receptor and mTOR seems to be essential for receptor-operated mTOR activation, which has been involved in cognitive deficits observed in neurodevelopmental models of schizophrenia (Meffre et al., 2012) as well as seizure activity of epileptic brain (L. Wang et al., 2015) in rodents. A more recent study revealed that $5-\mathrm{HT}_{6}$ receptor-neurofibromin interaction is critical for agonist-independent receptoroperated cAMP signaling in prefrontal cortex (Deraredj Nadim et al., 2016). Another study showed that the 5- $\mathrm{HT}_{6}$ receptor directly interacts with SNX14 and that this interaction promotes receptor internalization and degradation (Ha et al., 2015). Finally, the 5-HT 6 receptor was found to associate with a network of proteins, including $\mathrm{Cdk} 5$ and some of its regulator or substrates. These proteins are known to control actin cytoskeleton dynamics and key neurodevelopmental processes such as neuronal migration, neurite growth, and synapse morphogenesis (Duhr et al., 2014; Jacobshagen et al., 2014; Jessberger et al., 2009). As mentioned in chapter V, functional studies showed that agonist-independent activation of Cdk5 signaling by $5-\mathrm{HT}_{6}$ receptors plays a key role in its control of neuronal migration and differentiation during brain development (Duhr et al., 2014; Jacobshagen et al., 2014).

\section{$5-\mathrm{HT}_{7}$ receptor}


Using a yeast two-hybrid screening, Matthys et al. showed that the C-terminal domain of the 5$\mathrm{HT}_{7 \mathrm{a}}$ receptor directly interacts with RhoBTB3, an atypical Rho GTPase, which strongly inhibits proteasomal degradation of the receptor (Matthys et al., 2012). 5- $\mathrm{HT}_{7}$ receptors also bind to $\mathrm{S} 100 \mathrm{~B}$, a $\mathrm{Ca}^{2+}$-binding protein that serves as a biochemical predictor of behavioral responses to chronic fluoxetine treatment, via its i3 loop (Stroth \& Svenningsson, 2015). This interaction negatively regulates $5-\mathrm{HT}_{7}$ receptor-dependent cAMP production in transfected HeLa cells and mouse cortical astrocytes. It might also play a role in mood disorders as depressive-like behavior in the forced swim test (FST) observed in transgenic mice overexpressing $\mathrm{S} 100 \mathrm{~B}$ is normalized by pharmacological $5-\mathrm{HT}_{7}$ receptor blockade (Stroth \& Svenningsson, 2015). Finally, a recent study highlighted a physical interaction between the 5$\mathrm{HT}_{7}$ receptor and CD44, an MMP-9 substrate cleaved upon receptor activation in neurons and involved in receptor-mediated dendritic spine remodeling, synaptic pruning and impairment of LTP (Bijata et al., 2017).

\section{Concluding remarks}

Over the two last decades, our knowledge of $\mathrm{G}$ protein-dependent signaling mechanisms engaged by 5-HT receptors has probably achieved maturity. An important challenge is now to precisely determine where 5-HT receptors activate G proteins in the cells and the dynamics of G protein activation. Recently described single-molecule microscopy methods that allow direct visualization of GPCR:G protein interactions in living cells with unprecedented spatiotemporal resolution, will certainly provide a unique opportunity to address this question (Calebiro \& Sungkaworn, 2018). Beyond G protein signaling, identification of 5-HT receptor interactomes using genetics or proteomics strategies has proven efficiency to identify novel signaling pathways engaged by these receptors, as recently exemplified by the identification of novel 5$\mathrm{HT}_{6}$ and $5-\mathrm{HT}_{7}$ receptor-operated signaling pathways that underlie their role in neural development. Determination of crystal structures of 5-HT receptors will also be an important step in the understanding of 5-HT receptor activation process and of the mechanism of action 
of 5-HT receptor ligands, as well as in the development of drugs acting at 5-HT receptors. Given the importance of heteromer formation and the association of 5-HT receptors with GIPs in their signal transduction properties and functions, the next step will certainly be to determine structures of complexes made of 5-HT receptors and their protein partners.

\section{Acknowledgements}

All authors are supported by grants from CNRS, INSERM, Université de Montpellier and FRM. PM and CB are supported by grant from ANR ( $n^{\circ}$ ANR-17-CE16-0013-01), SCD by grant from ANR ( ${ }^{\circ}$ ANR-17-CE16-0010-01), SC by grants from Fondation Vaincre Alzheimer ( ${ }^{\circ}$ FR15072) and INSERM cross-cutting Program Microbiota. 


\section{References}

Abbas, A. I., Yadav, P. N., Yao, W. D., Arbuckle, M. I., Grant, S. G., Caron, M. G., \& Roth, B. L. (2009). PSD-95 is essential for hallucinogen and atypical antipsychotic drug actions at serotonin receptors. $J$ Neurosci, 29(22), 7124-7136. doi:10.1523/JNEUROSCI.1090-09.2009

Adayev, T., Ray, I., Sondhi, R., Sobocki, T., \& Banerjee, P. (2003). The G protein-coupled 5HT1A receptor causes suppression of caspase- 3 through MAPK and protein kinase Calpha. Biochim Biophys Acta, 1640(1), 85-96.

Adham, N., Kao, H. T., Schecter, L. E., Bard, J., Olsen, M., Urquhart, D., Durkin, M., Hartig, P. R., Weinshank, R. L., \& Branchek, T. A. (1993). Cloning of another human serotonin receptor $(5-\mathrm{HT} 1 \mathrm{~F})$ : a fifth 5-HT1 receptor subtype coupled to the inhibition of adenylate cyclase. Proc Natl Acad Sci U S A, 90(2), 408-412.

Al Awabdh, S., Miserey-Lenkei, S., Bouceba, T., Masson, J., Kano, F., Marinach-Patrice, C., Hamon, M., Emerit, M. B., \& Darmon, M. (2012). A new vesicular scaffolding complex mediates the G-protein-coupled 5-HT1A receptor targeting to neuronal dendrites. $J$ Neurosci, 32(41), 14227-14241. doi:10.1523/JNEUROSCI.6329-11.2012

Albert, P. R., Sajedi, N., Lemonde, S., \& Ghahremani, M. H. (1999). Constitutive G(i2)dependent activation of adenylyl cyclase type II by the 5-HT1A receptor. Inhibition by anxiolytic partial agonists. J Biol Chem, 274(50), 35469-35474.

Amaya-Castellanos, E., Pineda-Farias, J. B., Castaneda-Corral, G., Vidal-Cantu, G. C., Murbartian, J., Rocha-Gonzalez, H. I., \& Granados-Soto, V. (2011). Blockade of 5-HT7 receptors reduces tactile allodynia in the rat. Pharmacol Biochem Behav, 99(4), 591597. doi:10.1016/j.pbb.2011.06.005

Anastasio, N. C., Stutz, S. J., Fink, L. H., Swinford-Jackson, S. E., Sears, R. M., DiLeone, R. J., Rice, K. C., Moeller, F. G., \& Cunningham, K. A. (2015). Serotonin (5-HT) 5-HT2A Receptor (5-HT2AR):5-HT2CR Imbalance in Medial Prefrontal Cortex Associates with 
Motor Impulsivity. ACS Chem Neurosci, 6(7), 1248-1258. doi:10.1021/acschemneuro.5b00094

Anstey, M. L., Rogers, S. M., Ott, S. R., Burrows, M., \& Simpson, S. J. (2009). Serotonin mediates behavioral gregarization underlying swarm formation in desert locusts. Science, 323(5914), 627-630. doi:10.1126/science.1165939

Avila-Rojas, S. H., Velazquez-Lagunas, I., Salinas-Abarca, A. B., Barragan-Iglesias, P., Pineda-Farias, J. B., \& Granados-Soto, V. (2015). Role of spinal 5-HT5A, and 5$\mathrm{HT} 1 \mathrm{~A} / 1 \mathrm{~B} / 1 \mathrm{D}$, receptors in neuropathic pain induced by spinal nerve ligation in rats. Brain Res, 1622, 377-385. doi:10.1016/j.brainres.2015.06.043

Backer, J. M. (2008). The regulation and function of Class III PI3Ks: novel roles for Vps34. Biochem J, 410(1), 1-17. doi:10.1042/BJ20071427

Baranger, K., Giannoni, P., Girard, S. D., Girot, S., Gaven, F., Stephan, D., Migliorati, M., Khrestchatisky, M., Bockaert, J., Marchetti-Gauthier, E., Rivera, S., Claeysen, S., \& Roman, F. S. (2017). Chronic treatments with a 5-HT4 receptor agonist decrease amyloid pathology in the entorhinal cortex and learning and memory deficits in the 5xFAD mouse model of Alzheimer's disease. Neuropharmacology, 126, 128-141. doi:10.1016/j.neuropharm.2017.08.031

Barclay, Z., Dickson, L., Robertson, D. N., Johnson, M. S., Holland, P. J., Rosie, R., Sun, L., Fleetwood-Walker, S., Lutz, E. M., \& Mitchell, R. (2011). 5-HT2A receptor signalling through phospholipase D1 associated with its C-terminal tail. Biochem J, 436(3), 651660. doi:10.1042/BJ20101844

Bard, J. A., Zgombick, J., Adham, N., Vaysse, P., Branchek, T. A., \& Weinshank, R. L. (1993). Cloning of a novel human serotonin receptor (5-HT7) positively linked to adenylate cyclase. J Biol Chem, 268(31), 23422-23426.

Barnes, N. M., \& Sharp, T. (1999). A review of central 5-HT receptors and their function. Neuropharmacology, 38(8), 1083-1152. 
Barre, A., Berthoux, C., De Bundel, D., Valjent, E., Bockaert, J., Marin, P., \& Becamel, C. (2016). Presynaptic serotonin 2A receptors modulate thalamocortical plasticity and associative learning. Proc Natl Acad Sci U S A, 113(10), E1382-1391. doi:10.1073/pnas.1525586113

Barthet, G., Carrat, G., Cassier, E., Barker, B., Gaven, F., Pillot, M., Framery, B., Pellissier, L. P., Augier, J., Kang, D. S., Claeysen, S., Reiter, E., Baneres, J. L., Benovic, J. L., Marin, P., Bockaert, J., \& Dumuis, A. (2009). Beta-arrestin1 phosphorylation by GRK5 regulates $\mathrm{G}$ protein-independent 5-HT4 receptor signalling. EMBO J, 28(18), 27062718. doi:10.1038/emboj.2009.215

Becamel, C., Alonso, G., Galeotti, N., Demey, E., Jouin, P., Ullmer, C., Dumuis, A., Bockaert, J., \& Marin, P. (2002). Synaptic multiprotein complexes associated with 5-HT(2C) receptors: a proteomic approach. EMBO J, 21(10), 2332-2342. doi:10.1093/emboj/21.10.2332

Becamel, C., Figge, A., Poliak, S., Dumuis, A., Peles, E., Bockaert, J., Lubbert, H., \& Ullmer, C. (2001). Interaction of serotonin 5-hydroxytryptamine type 2C receptors with PDZ10 of the multi-PDZ domain protein MUPP1. J Biol Chem, 276(16), 12974-12982. doi:10.1074/jbc.M008089200

Becamel, C., Gavarini, S., Chanrion, B., Alonso, G., Galeotti, N., Dumuis, A., Bockaert, J., \& Marin, P. (2004). The serotonin 5-HT2A and 5-HT2C receptors interact with specific sets of PDZ proteins. J Biol Chem, 279(19), 20257-20266.

Bender, E., Pindon, A., van Oers, I., Zhang, Y. B., Gommeren, W., Verhasselt, P., Jurzak, M., Leysen, J., \& Luyten, W. (2000). Structure of the human serotonin 5-HT4 receptor gene and cloning of a novel 5-HT4 splice variant. J Neurochem, 74(2), 478-489.

Bennett, J. L., \& Aghajanian, G. K. (1974). d-LSD binding to brain homogenates: possible relationship to serotonin receptors. Life Sci, 15(11), 1935-1944.

Benvenga, M. J., Chaney, S. F., Baez, M., Britton, T. C., Hornback, W. J., Monn, J. A., \& Marek, G. J. (2018). Metabotropic Glutamate2 Receptors Play a Key Role in 
Modulating Head Twitches Induced by a Serotonergic Hallucinogen in Mice. Front Pharmacol, 9, 208. doi:10.3389/fphar.2018.00208

Berbari, N. F., Johnson, A. D., Lewis, J. S., Askwith, C. C., \& Mykytyn, K. (2008). Identification of ciliary localization sequences within the third intracellular loop of $\mathrm{G}$ protein-coupled receptors. Mol Biol Cell, 19(4), 1540-1547. doi:10.1091/mbc.E07-090942

Berg, K. A., Maayani, S., Goldfarb, J., \& Clarke, W. P. (1998). Pleiotropic behavior of 5-HT2A and 5-HT2C receptor agonists. Ann N Y Acad Sci, 861, 104-110.

Berthoux, C., Barre, A., Bockaert, J., Marin, P., \& Becamel, C. (2018). Sustained Activation of Postsynaptic 5-HT2A Receptors Gates Plasticity at Prefrontal Cortex Synapses. Cereb Cortex. doi:10.1093/cercor/bhy064

Bhalla, P., Saxena, P. R., \& Sharma, H. S. (2002). Molecular cloning and tissue distribution of mRNA encoding porcine 5-HT7 receptor and its comparison with the structure of other species. Mol Cell Biochem, 238(1-2), 81-88.

Bhatnagar, A., Sheffler, D. J., Kroeze, W. K., Compton-Toth, B., \& Roth, B. L. (2004). Caveolin-1 interacts with 5-HT2A serotonin receptors and profoundly modulates the signaling of selected Galphaq-coupled protein receptors. J Biol Chem, 279(33), 3461434623.

Bhattarai, Y., Williams, B. B., Battaglioli, E. J., Whitaker, W. R., Till, L., Grover, M., Linden, D. R., Akiba, Y., Kandimalla, K. K., Zachos, N. C., Kaunitz, J. D., Sonnenburg, J. L., Fischbach, M. A., Farrugia, G., \& Kashyap, P. C. (2018). Gut Microbiota-Produced Tryptamine Activates an Epithelial G-Protein-Coupled Receptor to Increase Colonic Secretion. Cell Host Microbe, 23(6), 775-785 e775. doi:10.1016/j.chom.2018.05.004

Bijata, M., Labus, J., Guseva, D., Stawarski, M., Butzlaff, M., Dzwonek, J., Schneeberg, J., Bohm, K., Michaluk, P., Rusakov, D. A., Dityatev, A., Wilczynski, G., Wlodarczyk, J., \& Ponimaskin, E. (2017). Synaptic Remodeling Depends on Signaling between 
Serotonin Receptors and the Extracellular Matrix. Cell Rep, 19(9), 1767-1782. doi:10.1016/j.celrep.2017.05.023

Blenau, W., \& Thamm, M. (2011). Distribution of serotonin (5-HT) and its receptors in the insect brain with focus on the mushroom bodies: lessons from Drosophila melanogaster and Apis mellifera. Arthropod Struct Dev, 40(5), 381-394. doi:10.1016/j.asd.2011.01.004

Bockaert, J., Claeysen, S., Becamel, C., Dumuis, A., \& Marin, P. (2006). Neuronal 5-HT metabotropic receptors: fine-tuning of their structure, signaling, and roles in synaptic modulation. Cell Tissue Res, 326(2), 553-572. doi:10.1007/s00441-006-0286-1

Bockaert, J., Claeysen, S., Compan, V., \& Dumuis, A. (2008). 5-HT(4) receptors: history, molecular pharmacology and brain functions. Neuropharmacology, 55(6), 922-931. doi:10.1016/j.neuropharm.2008.05.013

Bockaert, J., Claeysen, S., Compan, V., \& Dumuis, A. (2011). 5-HT(4) receptors, a place in the sun: act two. Curr Opin Pharmacol, 11(1), 87-93. doi:10.1016/j.coph.2011.01.012

Bockaert, J., Dumuis, A., Bouhelal, R., Sebben, M., \& Cory, R. N. (1987). Piperazine derivatives including the putative anxiolytic drugs, buspirone and ipsapirone, are agonists at 5-HT1A receptors negatively coupled with adenylate cyclase in hippocampal neurons. Naunyn Schmiedebergs Arch Pharmacol, 335(5), 588-592.

Bockaert, J., Fagni, L., Dumuis, A., \& Marin, P. (2004). GPCR interacting proteins (GIP). Pharmacol Ther, 103(3), 203-221.

Bockaert, J., Fozard, J. R., Dumuis, A., \& Clarke, D. E. (1992). The 5-HT4 receptor: a place in the sun. Trends Pharmacol Sci, 13(4), 141-145.

Bockaert, J., Sebben, M., \& Dumuis, A. (1990). Pharmacological characterization of 5hydroxytryptamine4(5-HT4) receptors positively coupled to adenylate cyclase in adult guinea pig hippocampal membranes: effect of substituted benzamide derivatives. Mol Pharmacol, 37(3), 408-411. 
Boess, F. G., Beroukhim, R., \& Martin, I. L. (1995). Ultrastructure of the 5-hydroxytryptamine3 receptor. J Neurochem, 64(3), 1401-1405.

Borroto-Escuela, D. O., Li, X., Tarakanov, A. O., Savelli, D., Narvaez, M., Shumilov, K., Andrade-Talavera, Y., Jimenez-Beristain, A., Pomierny, B., Diaz-Cabiale, Z., Cuppini, R., Ambrogini, P., Lindskog, M., \& Fuxe, K. (2017). Existence of Brain 5-HT1A-5HT2A Isoreceptor Complexes with Antagonistic Allosteric Receptor-Receptor Interactions Regulating 5-HT1A Receptor Recognition. ACS Omega, 2(8), 4779-4789. doi:10.1021/acsomega.7b00629

Borroto-Escuela, D. O., Narvaez, M., Marcellino, D., Parrado, C., Narvaez, J. A., Tarakanov, A. O., Agnati, L. F., Diaz-Cabiale, Z., \& Fuxe, K. (2010). Galanin receptor-1 modulates 5-hydroxtryptamine-1A signaling via heterodimerization. Biochem Biophys Res Commun, 393(4), 767-772. doi:10.1016/j.bbrc.2010.02.078

Borroto-Escuela, D. O., Romero-Fernandez, W., Tarakanov, A. O., Marcellino, D., Ciruela, F., Agnati, L. F., \& Fuxe, K. (2010). Dopamine D2 and 5-hydroxytryptamine 5-HT((2)A) receptors assemble into functionally interacting heteromers. Biochem Biophys Res Commun, 401(4), 605-610. doi:10.1016/j.bbrc.2010.09.110

Borsini, F., Bordi, F., Poggi, A., \& Di Matteo, V. (2015). Effects of ST1936, a selective serotonin-6 agonist, on electrical activity of putative mesencephalic dopaminergic neurons in the rat brain. J Psychopharmacol, 29(7), 802-811. doi:10.1177/0269881115573804

Bouhelal, R., Smounya, L., \& Bockaert, J. (1988). 5-HT1B receptors are negatively coupled with adenylate cyclase in rat substantia nigra. Eur J Pharmacol, 151(2), 189-196.

Bradley, P. B., Engel, G., Feniuk, W., Fozard, J. R., Humphrey, P. P., Middlemiss, D. N., Mylecharane, E. J., Richardson, B. P., \& Saxena, P. R. (1986). Proposals for the classification and nomenclature of functional receptors for 5-hydroxytryptamine. Neuropharmacology, 25(6), 563-576. 
Brailov, I., Bancila, M., Brisorgueil, M. J., Miquel, M. C., Hamon, M., \& Verge, D. (2000). Localization of 5-HT(6) receptors at the plasma membrane of neuronal cilia in the rat brain. Brain Res, 872(1-2), 271-275.

Brea, J., Castro, M., Giraldo, J., Lopez-Gimenez, J. F., Padin, J. F., Quintian, F., Cadavid, M. I., Vilaro, M. T., Mengod, G., Berg, K. A., Clarke, W. P., Vilardaga, J. P., Milligan, G., \& Loza, M. I. (2009). Evidence for distinct antagonist-revealed functional states of 5hydroxytryptamine(2A) receptor homodimers. Mol Pharmacol, 75(6), 1380-1391. doi:10.1124/mol.108.054395

Brenchat, A., Romero, L., Garcia, M., Pujol, M., Burgueno, J., Torrens, A., Hamon, M., Baeyens, J. M., Buschmann, H., Zamanillo, D., \& Vela, J. M. (2009). 5-HT7 receptor activation inhibits mechanical hypersensitivity secondary to capsaicin sensitization in mice. Pain, 141(3), 239-247. doi:10.1016/j.pain.2008.11.009

Brodsky, M., Lesiak, A. J., Croicu, A., Cohenca, N., Sullivan, J. M., \& Neumaier, J. F. (2017). 5-HT6 receptor blockade regulates primary cilia morphology in striatal neurons. Brain Res, 1660, 10-19. doi:10.1016/j.brainres.2017.01.010

Cadogan, A. K., Kendall, D. A., \& Marsden, C. A. (1994). Serotonin 5-HT1A receptor activation increases cyclic AMP formation in the rat hippocampus in vivo. $J$ Neurochem, 62(5), 1816-1821.

Calebiro, D., \& Sungkaworn, T. (2018). Single-Molecule Imaging of GPCR Interactions. Trends Pharmacol Sci, 39(2), 109-122. doi:10.1016/j.tips.2017.10.010

Carrel, D., Masson, J., Al Awabdh, S., Capra, C. B., Lenkei, Z., Hamon, M., Emerit, M. B., \& Darmon, M. (2008). Targeting of the 5-HT1A serotonin receptor to neuronal dendrites is mediated by Yif1B. J Neurosci, 28(32), 8063-8073. doi:10.1523/JNEUROSCI.448707.2008

Cassier, E., Gallay, N., Bourquard, T., Claeysen, S., Bockaert, J., Crepieux, P., Poupon, A., Reiter, E., Marin, P., \& Vandermoere, F. (2017). Phosphorylation of beta-arrestin2 at 
$\operatorname{Thr}(383)$ by MEK underlies beta-arrestin-dependent activation of Erk1/2 by GPCRs. Elife, 6. doi:10.7554/eLife.23777

Chen, L. T., Gilman, A. G., \& Kozasa, T. (1999). A candidate target for G protein action in brain. J Biol Chem, 274(38), 26931-26938.

Claeysen, S., Cochet, M., Donneger, R., Dumuis, A., Bockaert, J., \& Giannoni, P. (2012). Alzheimer culprits: cellular crossroads and interplay. Cell Signal, 24(9), 1831-1840. doi:10.1016/j.cellsig.2012.05.008

Claeysen, S., Sebben, M., Becamel, C., Bockaert, J., \& Dumuis, A. (1999). Novel brain-specific 5-HT4 receptor splice variants show marked constitutive activity: role of the C-terminal intracellular domain. Mol Pharmacol, 55(5), 910-920.

Cochet, M., Donneger, R., Cassier, E., Gaven, F., Lichtenthaler, S. F., Marin, P., Bockaert, J., Dumuis, A., \& Claeysen, S. (2013). 5-HT4 receptors constitutively promote the nonamyloidogenic pathway of APP cleavage and interact with ADAM10. ACS Chem Neurosci, 4(1), 130-140. doi:10.1021/cn300095t

Cogolludo, A., Moreno, L., Lodi, F., Frazziano, G., Cobeno, L., Tamargo, J., \& Perez-Vizcaino, F. (2006). Serotonin Inhibits Voltage-Gated K+ Currents in Pulmonary Artery Smooth Muscle Cells. Role of 5-HT2A Receptors, Caveolin-1, and KV1.5 Channel Internalization. Circ Res.

Conn, P. J., \& Sanders-Bush, E. (1984). Selective 5HT-2 antagonists inhibit serotonin stimulated phosphatidylinositol metabolism in cerebral cortex. Neuropharmacology, 23(8), 993-996.

Corbett, D. F., Heightman, T. D., Moss, S. F., Bromidge, S. M., Coggon, S. A., Longley, M. J., Roa, A. M., Williams, J. A., \& Thomas, D. R. (2005). Discovery of a potent and selective 5-ht5A receptor antagonist by high-throughput chemistry. Bioorg Med Chem Lett, 15(18), 4014-4018. doi:10.1016/j.bmcl.2005.06.024

Costa, L., Sardone, L. M., Lacivita, E., Leopoldo, M., \& Ciranna, L. (2015). Novel agonists for serotonin 5-HT7 receptors reverse metabotropic glutamate receptor-mediated long-term 
depression in the hippocampus of wild-type and Fmr1 KO mice, a model of Fragile X Syndrome. Front Behav Neurosci, 9, 65. doi:10.3389/fnbeh.2015.00065

Cowen, D. S., Johnson-Farley, N. N., \& Travkina, T. (2005). 5-HT receptors couple to activation of Akt, but not extracellular-regulated kinase (ERK), in cultured hippocampal neurons. J Neurochem, 93(4), 910-917. doi:10.1111/j.1471-4159.2005.03107.x

Crane, J. W., Shimizu, K., Carrasco, G. A., Garcia, F., Jia, C., Sullivan, N. R., D'Souza, D. N., Zhang, Y., Van de Kar, L. D., Muma, N. A., \& Battaglia, G. (2007). 5-HT1A receptors mediate $(+) 8$-OH-DPAT-stimulation of extracellular signal-regulated kinase (MAP kinase) in vivo in rat hypothalamus: time dependence and regional differences. Brain Res, 1183, 51-59. doi:10.1016/j.brainres.2007.07.101

Curtin, P. C., Medan, V., Neumeister, H., Bronson, D. R., \& Preuss, T. (2013). The 5-HT5A receptor regulates excitability in the auditory startle circuit: functional implications for sensorimotor gating. $J \quad$ Neurosci, $33(24), \quad$ 10011-10020. doi:10.1523/JNEUROSCI.4733-12.2013

Cussac, D., Rauly-Lestienne, I., Heusler, P., Finana, F., Cathala, C., Bernois, S., \& De Vries, L. (2012). mu-Opioid and 5-HT1A receptors heterodimerize and show signalling crosstalk via G protein and MAP-kinase pathways. Cell Signal, 24(8), 1648-1657. doi:10.1016/j.cellsig.2012.04.010

de Jong, I. E. M., \& Mork, A. (2017). Antagonism of the 5-HT6 receptor - Preclinical rationale for the treatment of Alzheimer's disease. Neuropharmacology, 125, 50-63. doi:10.1016/j.neuropharm.2017.07.010

De Vadder, F., Grasset, E., Manneras Holm, L., Karsenty, G., Macpherson, A. J., Olofsson, L. E., \& Backhed, F. (2018). Gut microbiota regulates maturation of the adult enteric nervous system via enteric serotonin networks. Proc Natl Acad Sci U S A, 115(25), 6458-6463. doi:10.1073/pnas. 1720017115 
De Vivo, M., \& Maayani, S. (1986). Characterization of the 5-hydroxytryptamine1a receptormediated inhibition of forskolin-stimulated adenylate cyclase activity in guinea pig and rat hippocampal membranes. J Pharmacol Exp Ther, 238(1), 248-253.

Delille, H. K., Mezler, M., \& Marek, G. J. (2013). The two faces of the pharmacological interaction of mGlu2 and 5-HT(2)A - relevance of receptor heterocomplexes and interaction through functional brain pathways. Neuropharmacology, 70, 296-305. doi:10.1016/j.neuropharm.2013.02.005

Della Rocca, G. J., Mukhin, Y. V., Garnovskaya, M. N., Daaka, Y., Clark, G. J., Luttrell, L. M., Lefkowitz, R. J., \& Raymond, J. R. (1999). Serotonin 5-HT1A receptor-mediated Erk activation requires calcium/calmodulin-dependent receptor endocytosis. $J$ Biol Chem, 274(8), 4749-4753.

Deraredj Nadim, W., Chaumont-Dubel, S., Madouri, F., Cobret, L., De Tauzia, M. L., Zajdel, P., Benedetti, H., Marin, P., \& Morisset-Lopez, S. (2016). Physical interaction between neurofibromin and serotonin 5-HT6 receptor promotes receptor constitutive activity. Proc Natl Acad Sci US A, 113(43), 12310-12315. doi:10.1073/pnas.1600914113

Derkach, V., Surprenant, A., \& North, R. A. (1989). 5-HT3 receptors are membrane ion channels. Nature, 339(6227), 706-709. doi:10.1038/339706a0

Doly, S., Fischer, J., Brisorgueil, M. J., Verge, D., \& Conrath, M. (2005). Pre- and postsynaptic localization of the 5-HT7 receptor in rat dorsal spinal cord: immunocytochemical evidence. J Comp Neurol, 490(3), 256-269. doi:10.1002/cne.20667

Duhr, F., Deleris, P., Raynaud, F., Seveno, M., Morisset-Lopez, S., Mannoury la Cour, C., Millan, M. J., Bockaert, J., Marin, P., \& Chaumont-Dubel, S. (2014). Cdk5 induces constitutive activation of 5-HT6 receptors to promote neurite growth. Nat Chem Biol, 10(7), 590-597. doi:10.1038/nchembio. 1547

Dumuis, A., Bouhelal, R., Sebben, M., Cory, R., \& Bockaert, J. (1988). A nonclassical 5hydroxytryptamine receptor positively coupled with adenylate cyclase in the central nervous system. Mol Pharmacol, 34(6), 880-887. 
Dumuis, A., Sebben, M., \& Bockaert, J. (1989). The gastrointestinal prokinetic benzamide derivatives are agonists at the non-classical 5-HT receptor (5-HT4) positively coupled to adenylate cyclase in neurons. Naunyn Schmiedebergs Arch Pharmacol, 340(4), 403410.

Dunn, H. A., Walther, C., Yuan, G. Y., Caetano, F. A., Godin, C. M., \& Ferguson, S. S. (2014). Role of SAP97 in the regulation of 5-HT2AR endocytosis and signaling. Mol Pharmacol, 86(3), 275-283. doi:10.1124/mol.114.093476

Dusonchet, J., Bensadoun, J. C., Schneider, B. L., \& Aebischer, P. (2009). Targeted overexpression of the parkin substrate Pael-R in the nigrostriatal system of adult rats to model Parkinson's disease. Neurobiol Dis, 35(1), 32-41. doi:10.1016/j.nbd.2009.03.013

Eran, A., Li, J. B., Vatalaro, K., McCarthy, J., Rahimov, F., Collins, C., Markianos, K., Margulies, D. M., Brown, E. N., Calvo, S. E., Kohane, I. S., \& Kunkel, L. M. (2013). Comparative RNA editing in autistic and neurotypical cerebella. Mol Psychiatry, 18(9), 1041-1048. doi:10.1038/mp.2012.118

Eriksson, T. M., Alvarsson, A., Stan, T. L., Zhang, X., Hascup, K. N., Hascup, E. R., Kehr, J., Gerhardt, G. A., Warner-Schmidt, J., Arango-Lievano, M., Kaplitt, M. G., Ogren, S. O., Greengard, P., \& Svenningsson, P. (2013). Bidirectional regulation of emotional memory by 5-HT1B receptors involves hippocampal p11. Mol Psychiatry, 18(10), 1096-1105. doi:10.1038/mp.2012.130

Erland, L. A., Turi, C. E., \& Saxena, P. K. (2016). Serotonin: An ancient molecule and an important regulator of plant processes. Biotechnol Adv, 34(8), 1347-1361. doi:10.1016/j.biotechadv.2016.10.002

Errico, M., Crozier, R. A., Plummer, M. R., \& Cowen, D. S. (2001). 5-HT(7) receptors activate the mitogen activated protein kinase extracellular signal related kinase in cultured rat hippocampal neurons. Neuroscience, 102(2), 361-367.

Fagerberg, L., Hallstrom, B. M., Oksvold, P., Kampf, C., Djureinovic, D., Odeberg, J., Habuka, M., Tahmasebpoor, S., Danielsson, A., Edlund, K., Asplund, A., Sjostedt, E., Lundberg, 
E., Szigyarto, C. A., Skogs, M., Takanen, J. O., Berling, H., Tegel, H., Mulder, J., Nilsson, P., Schwenk, J. M., Lindskog, C., Danielsson, F., Mardinoglu, A., Sivertsson, A., von Feilitzen, K., Forsberg, M., Zwahlen, M., Olsson, I., Navani, S., Huss, M., Nielsen, J., Ponten, F., \& Uhlen, M. (2014). Analysis of the human tissue-specific expression by genome-wide integration of transcriptomics and antibody-based proteomics. Mol Cell Proteomics, 13(2), 397-406. doi:10.1074/mcp.M113.035600

Fargin, A., Raymond, J. R., Lohse, M. J., Kobilka, B. K., Caron, M. G., \& Lefkowitz, R. J. (1988). The genomic clone G-21 which resembles a beta-adrenergic receptor sequence encodes the 5-HT1A receptor. Nature, 335(6188), 358-360. doi:10.1038/335358a0

Felder, C. C., Kanterman, R. Y., Ma, A. L., \& Axelrod, J. (1990). Serotonin stimulates phospholipase A2 and the release of arachidonic acid in hippocampal neurons by a type 2 serotonin receptor that is independent of inositolphospholipid hydrolysis. Proc Natl Acad Sci U S A, 87(6), 2187-2191.

Felsing, D. E., Anastasio, N. C., Miszkiel, J. M., Gilbertson, S. R., Allen, J. A., \& Cunningham, K. A. (2018). Biophysical validation of serotonin 5-HT2A and 5-HT2C receptor interaction. PLoS One, 13(8), e0203137. doi:10.1371/journal.pone.0203137

Fillion, G., Fillion, M. P., Jacob, J., \& Rousselle, J. C. (1976). 5-HT and LSD high affinity binding sites to brain synaptosomal membranes [proceedings]. Br J Pharmacol, 58(3), 425P-426P.

Flores-Burgess, A., Millon, C., Gago, B., Narvaez, M., Borroto-Escuela, D. O., Mengod, G., Narvaez, J. A., Fuxe, K., Santin, L., \& Diaz-Cabiale, Z. (2017). Galanin (1-15) enhancement of the behavioral effects of Fluoxetine in the forced swimming test gives a new therapeutic strategy against depression. Neuropharmacology, 118, 233-241. doi:10.1016/j.neuropharm.2017.03.010

Foguet, M., Hoyer, D., Pardo, L. A., Parekh, A., Kluxen, F. W., Kalkman, H. O., Stuhmer, W., \& Lubbert, H. (1992). Cloning and functional characterization of the rat stomach fundus serotonin receptor. EMBO J, 11(9), 3481-3487. 
Fribourg, M., Moreno, J. L., Holloway, T., Provasi, D., Baki, L., Mahajan, R., Park, G., Adney, S. K., Hatcher, C., Eltit, J. M., Ruta, J. D., Albizu, L., Li, Z., Umali, A., Shim, J., Fabiato, A., MacKerell, A. D., Jr., Brezina, V., Sealfon, S. C., Filizola, M., Gonzalez-Maeso, J., \& Logothetis, D. E. (2011). Decoding the signaling of a GPCR heteromeric complex reveals a unifying mechanism of action of antipsychotic drugs. Cell, 147(5), 1011-1023. doi:10.1016/j.cell.2011.09.055

Fukumoto, K., Iijima, M., Funakoshi, T., \& Chaki, S. (2018a). 5-HT1A receptor stimulation in the medial prefrontal cortex mediates the antidepressant effects of mGlu2/3 receptor antagonist in mice. Neuropharmacology, 137, 96-103. doi:10.1016/j.neuropharm.2018.05.001

Fukumoto, K., Iijima, M., Funakoshi, T., \& Chaki, S. (2018b). Role of 5-HT1A Receptor Stimulation in the Medial Prefrontal Cortex in the Sustained Antidepressant Effects of Ketamine. Int J Neuropsychopharmacol, 21(4), 371-381. doi:10.1093/ijnp/pyx116

Gaddum, J. H. (1953). Antagonism between lysergic acid diethylamide and 5hydroxytryptamine. J Physiol, 121(1), 15P.

Gaddum, J. H., \& Picarelli, Z. P. (1957). Two kinds of tryptamine receptor. Br J Pharmacol Chemother, 12(3), 323-328.

Garcia-Nafria, J., Nehme, R., Edwards, P. C., \& Tate, C. G. (2018). Cryo-EM structure of the serotonin 5-HT1B receptor coupled to heterotrimeric Go. Nature, 558(7711), 620-623. doi:10.1038/s41586-018-0241-9

Gavarini, S., Becamel, C., Altier, C., Lory, P., Poncet, J., Wijnholds, J., Bockaert, J., \& Marin, P. (2006). Opposite Effects of PSD-95 and MPP3 PDZ Proteins on Serotonin 5Hydroxytryptamine2C Receptor Desensitization and Membrane Stability. Mol Biol Cell, 17(11), 4619-4631.

Gerard, C., Martres, M. P., Lefevre, K., Miquel, M. C., Verge, D., Lanfumey, L., Doucet, E., Hamon, M., \& el Mestikawy, S. (1997). Immuno-localization of serotonin 5-HT6 receptor-like material in the rat central nervous system. Brain Res, 746(1-2), 207-219. 
Giannoni, P., Gaven, F., de Bundel, D., Baranger, K., Marchetti-Gauthier, E., Roman, F. S., Valjent, E., Marin, P., Bockaert, J., Rivera, S., \& Claeysen, S. (2013). Early administration of RS 67333, a specific 5-HT4 receptor agonist, prevents amyloidogenesis and behavioral deficits in the 5XFAD mouse model of Alzheimer's disease. Front Aging Neurosci, 5, 96. doi:10.3389/fnagi.2013.00096

Glatt-Deeley, H., Bancescu, D. L., \& Lalande, M. (2010). Prader-Willi syndrome, Snord115, and Htr2c editing. Neurogenetics, 11(1), 143-144. doi:10.1007/s10048-009-0209-x

Gonzalez-Maeso, J., Ang, R. L., Yuen, T., Chan, P., Weisstaub, N. V., Lopez-Gimenez, J. F., Zhou, M., Okawa, Y., Callado, L. F., Milligan, G., Gingrich, J. A., Filizola, M., Meana, J. J., \& Sealfon, S. C. (2008). Identification of a serotonin/glutamate receptor complex implicated in psychosis. Nature, 452(7183), 93-97. doi:10.1038/nature06612

Gonzalez-Maeso, J., \& Sealfon, S. C. (2009). Agonist-trafficking and hallucinogens. Curr Med Chem, 16(8), 1017-1027.

Gonzalez-Maeso, J., Weisstaub, N. V., Zhou, M., Chan, P., Ivic, L., Ang, R., Lira, A., BradleyMoore, M., Ge, Y., Zhou, Q., Sealfon, S. C., \& Gingrich, J. A. (2007). Hallucinogens recruit specific cortical 5-HT(2A) receptor-mediated signaling pathways to affect behavior. Neuron, 53(3), 439-452. doi:10.1016/j.neuron.2007.01.008

Goodfellow, N. M., Bailey, C. D., \& Lambe, E. K. (2012). The native serotonin 5-HT(5A) receptor: electrophysiological characterization in rodent cortex and 5-HT(1A)-mediated compensatory plasticity in the knock-out mouse. $J$ Neurosci, 32(17), 5804-5809. doi:10.1523/JNEUROSCI.4849-11.2012

Gozlan, H., El Mestikawy, S., Pichat, L., Glowinski, J., \& Hamon, M. (1983). Identification of presynaptic serotonin autoreceptors using a new ligand: 3H-PAT. Nature, 305(5930), $140-142$.

Grailhe, R., Grabtree, G. W., \& Hen, R. (2001). Human 5-HT(5) receptors: the 5-HT(5A) receptor is functional but the 5-HT(5B) receptor was lost during mammalian evolution. Eur J Pharmacol, 418(3), 157-167. 
Gu, Z., Jiang, Q., \& Yan, Z. (2007). RGS4 modulates serotonin signaling in prefrontal cortex and links to serotonin dysfunction in a rat model of schizophrenia. Mol Pharmacol, 71(4), 1030-1039. doi:10.1124/mol.106.032490

Gurbuz, N., Ashour, A. A., Alpay, S. N., \& Ozpolat, B. (2014). Down-regulation of 5-HT1B and 5-HT1D receptors inhibits proliferation, clonogenicity and invasion of human pancreatic cancer cells. PLoS One, 9(9), e110067. doi:10.1371/journal.pone.0110067

Gurevich, I., Englander, M. T., Adlersberg, M., Siegal, N. B., \& Schmauss, C. (2002). Modulation of serotonin $2 \mathrm{C}$ receptor editing by sustained changes in serotonergic neurotransmission. J Neurosci, 22(24), 10529-10532.

Gurevich, I., Tamir, H., Arango, V., Dwork, A. J., Mann, J. J., \& Schmauss, C. (2002). Altered editing of serotonin $2 \mathrm{C}$ receptor pre-mRNA in the prefrontal cortex of depressed suicide victims. Neuron, 34(3), 349-356.

Ha, C. M., Park, D., Kim, Y., Na, M., Panda, S., Won, S., Kim, H., Ryu, H., Park, Z. Y., Rasenick, M. M., \& Chang, S. (2015). SNX14 is a bifunctional negative regulator for neuronal 5-HT6 receptor signaling. $J$ Cell Sci, 128(9), 1848-1861. doi:10.1242/jcs.169581

Hagan, J. J., Price, G. W., Jeffrey, P., Deeks, N. J., Stean, T., Piper, D., Smith, M. I., Upton, N., Medhurst, A. D., Middlemiss, D. N., Riley, G. J., Lovell, P. J., Bromidge, S. M., \& Thomas, D. R. (2000). Characterization of SB-269970-A, a selective 5-HT(7) receptor antagonist. Br J Pharmacol, 130(3), 539-548. doi:10.1038/sj.bjp.0703357

Hajj-Ali, I., \& Anctil, M. (1997). Characterization of a serotonin receptor in the cnidarian Renilla koellikeri: a radiobinding analysis. Neurochem Int, 31(1), 83-93.

Hammad, M. M., Dunn, H. A., \& Ferguson, S. S. G. (2018). MAGI proteins can differentially regulate the signaling pathways of 5-HT2AR by enhancing receptor trafficking and PLC recruitment. Cell Signal, 47, 109-121. doi:10.1016/j.cellsig.2018.03.016

Hassaine, G., Deluz, C., Grasso, L., Wyss, R., Tol, M. B., Hovius, R., Graff, A., Stahlberg, H., Tomizaki, T., Desmyter, A., Moreau, C., Li, X. D., Poitevin, F., Vogel, H., \& Nury, H. 
(2014). X-ray structure of the mouse serotonin 5-HT3 receptor. Nature, 512(7514), 276281. doi:10.1038/nature13552

Heal, D. J., Smith, S. L., Fisas, A., Codony, X., \& Buschmann, H. (2008). Selective 5-HT6 receptor ligands: progress in the development of a novel pharmacological approach to the treatment of obesity and related metabolic disorders. Pharmacol Ther, 117(2), 207231. doi:10.1016/j.pharmthera.2007.08.006

Helboe, L., Egebjerg, J., \& de Jong, I. E. (2015). Distribution of serotonin receptor 5-HT6 mRNA in rat neuronal subpopulations: A double in situ hybridization study. Neuroscience, 310, 442-454. doi:10.1016/j.neuroscience.2015.09.064

Herrick-Davis, K., Grinde, E., Lindsley, T., Teitler, M., Mancia, F., Cowan, A., \& Mazurkiewicz, J. E. (2015). Native serotonin 5-HT2C receptors are expressed as homodimers on the apical surface of choroid plexus epithelial cells. Mol Pharmacol, 87(4), 660-673. doi:10.1124/mol.114.096636

Herrick-Davis, K., Grinde, E., \& Niswender, C. M. (1999). Serotonin 5-HT2C receptor RNA editing alters receptor basal activity: implications for serotonergic signal transduction. J Neurochem, 73(4), 1711-1717.

Herrick-Davis, K., Weaver, B. A., Grinde, E., \& Mazurkiewicz, J. E. (2006). Serotonin 5-HT2C receptor homodimer biogenesis in the endoplasmic reticulum: real-time visualization with confocal fluorescence resonance energy transfer. J Biol Chem, 281(37), 2710927116. doi:10.1074/jbc.M604390200

Hirst, W. D., Abrahamsen, B., Blaney, F. E., Calver, A. R., Aloj, L., Price, G. W., \& Medhurst, A. D. (2003). Differences in the central nervous system distribution and pharmacology of the mouse 5-hydroxytryptamine-6 receptor compared with rat and human receptors investigated by radioligand binding, site-directed mutagenesis, and molecular modeling. Mol Pharmacol, 64(6), 1295-1308. doi:10.1124/mol.64.6.1295

Hirst, W. D., Stean, T. O., Rogers, D. C., Sunter, D., Pugh, P., Moss, S. F., Bromidge, S. M., Riley, G., Smith, D. R., Bartlett, S., Heidbreder, C. A., Atkins, A. R., Lacroix, L. P., 
Dawson, L. A., Foley, A. G., Regan, C. M., \& Upton, N. (2006). SB-399885 is a potent, selective 5-HT6 receptor antagonist with cognitive enhancing properties in aged rat water maze and novel object recognition models. Eur J Pharmacol, 553(1-3), 109-119. doi:10.1016/j.ejphar.2006.09.049

Hobson, R. J., Geng, J., Gray, A. D., \& Komuniecki, R. W. (2003). SER-7b, a constitutively active Galphas coupled 5-HT7-like receptor expressed in the Caenorhabditis elegans M4 pharyngeal motorneuron. $J$ Neurochem, 87(1), 22-29.

Horiguchi, M., Huang, M., \& Meltzer, H. Y. (2011). The role of 5-hydroxytryptamine 7 receptors in the phencyclidine-induced novel object recognition deficit in rats. $J$ Pharmacol Exp Ther, 338(2), 605-614. doi:10.1124/jpet.111.180638

Hoyer, D., Clarke, D. E., Fozard, J. R., Hartig, P. R., Martin, G. R., Mylecharane, E. J., Saxena, P. R., \& Humphrey, P. P. (1994). International Union of Pharmacology classification of receptors for 5-hydroxytryptamine (Serotonin). Pharmacol Rev, 46(2), 157-203.

Hoyer, D., Engel, G., \& Kalkman, H. O. (1985). Characterization of the 5-HT1B recognition site in rat brain: binding studies with (-)[125I]iodocyanopindolol. Eur J Pharmacol, $118(1-2), 1-12$

Hoyer, D., \& Middlemiss, D. N. (1989). Species differences in the pharmacology of terminal 5-HT autoreceptors in mammalian brain. Trends Pharmacol Sci, 10(4), 130-132.

Humphrey, P. P. (2008). The discovery and development of the triptans, a major therapeutic breakthrough. Headache, 48(5), 685-687. doi:10.1111/j.1526-4610.2008.01097.x

Jacobshagen, M., Niquille, M., Chaumont-Dubel, S., Marin, P., \& Dayer, A. (2014). The serotonin 6 receptor controls neuronal migration during corticogenesis via a ligandindependent Cdk5-dependent mechanism. Development, 141(17), 3370-3377. doi:10.1242/dev.108043

Jessberger, S., Gage, F. H., Eisch, A. J., \& Lagace, D. C. (2009). Making a neuron: Cdk5 in embryonic and adult neurogenesis. Trends Neurosci, 32(11), 575-582. doi:10.1016/j.tins.2009.07.002 
Ji, S. P., Zhang, Y., Van Cleemput, J., Jiang, W., Liao, M., Li, L., Wan, Q., Backstrom, J. R., \& Zhang, X. (2006). Disruption of PTEN coupling with 5-HT2C receptors suppresses behavioral responses induced by drugs of abuse. Nat Med, 12(3), 324-329.

Johannessen, C. M., Reczek, E. E., James, M. F., Brems, H., Legius, E., \& Cichowski, K. (2005). The NF1 tumor suppressor critically regulates TSC2 and mTOR. Proc Natl Acad Sci U S A, 102(24), 8573-8578. doi:10.1073/pnas.0503224102

Joubert, L., Hanson, B., Barthet, G., Sebben, M., Claeysen, S., Hong, W., Marin, P., Dumuis, A., \& Bockaert, J. (2004). New sorting nexin (SNX27) and NHERF specifically interact with the 5-HT4a receptor splice variant: roles in receptor targeting. J Cell Sci, 117(Pt 22), 5367-5379. doi:10.1242/jcs.01379

Kamal, M., Gbahou, F., Guillaume, J. L., Daulat, A. M., Benleulmi-Chaachoua, A., Luka, M., Chen, P., Kalbasi Anaraki, D., Baroncini, M., Mannoury la Cour, C., Millan, M. J., Prevot, V., Delagrange, P., \& Jockers, R. (2015). Convergence of melatonin and serotonin (5-HT) signaling at MT2/5-HT2C receptor heteromers. J Biol Chem, 290(18), 11537-11546. doi:10.1074/jbc.M114.559542

Karaki, S., Becamel, C., Murat, S., Mannoury la Cour, C., Millan, M. J., Prezeau, L., Bockaert, J., Marin, P., \& Vandermoere, F. (2014). Quantitative phosphoproteomics unravels biased phosphorylation of serotonin $2 \mathrm{~A}$ receptor at Ser280 by hallucinogenic versus nonhallucinogenic agonists. Mol Cell Proteomics, 13(5), 1273-1285. doi:10.1074/mcp.M113.036558

Kim, S. H., Kim, D. H., Lee, K. H., Im, S. K., Hur, E. M., Chung, K. C., \& Rhim, H. (2014). Direct interaction and functional coupling between human 5-HT6 receptor and the light chain 1 subunit of the microtubule-associated protein 1B (MAP1B-LC1). PLoS One, 9(3), e91402. doi:10.1371/journal.pone.0091402

Kleene, R., Chaudhary, H., Karl, N., Katic, J., Kotarska, A., Guitart, K., Loers, G., \& Schachner, M. (2015). Interaction between CHL1 and serotonin receptor 2c regulates 
signal transduction and behavior in mice. $J$ Cell Sci, 128(24), 4642-4652. doi:10.1242/jcs.176941

Kobe, F., Renner, U., Woehler, A., Wlodarczyk, J., Papusheva, E., Bao, G., Zeug, A., Richter, D. W., Neher, E., \& Ponimaskin, E. (2008). Stimulation- and palmitoylation-dependent changes in oligomeric conformation of serotonin 5-HT1A receptors. Biochim Biophys Acta, 1783(8), 1503-1516. doi:10.1016/j.bbamcr.2008.02.021

Kohen, R., Fashingbauer, L. A., Heidmann, D. E., Guthrie, C. R., \& Hamblin, M. W. (2001). Cloning of the mouse 5-HT6 serotonin receptor and mutagenesis studies of the third cytoplasmic loop. Brain Res Mol Brain Res, 90(2), 110-117.

Kohen, R., Metcalf, M. A., Khan, N., Druck, T., Huebner, K., Lachowicz, J. E., Meltzer, H. Y., Sibley, D. R., Roth, B. L., \& Hamblin, M. W. (1996). Cloning, characterization, and chromosomal localization of a human 5-HT6 serotonin receptor. J Neurochem, 66(1), 47-56.

Kolasa, M., Solich, J., Faron-Gorecka, A., Zurawek, D., Pabian, P., Lukasiewicz, S., Kusmider, M., Szafran-Pilch, K., Szlachta, M., \& Dziedzicka-Wasylewska, M. (2018). Paroxetine and Low-dose Risperidone Induce Serotonin 5-HT1A and Dopamine D2 Receptor Heteromerization in the Mouse Prefrontal Cortex. Neuroscience, 377, 184-196. doi:10.1016/j.neuroscience.2018.03.004

Kruk, J. S., Vasefi, M. S., Liu, H., Heikkila, J. J., \& Beazely, M. A. (2013). 5-HT(1A) receptors transactivate the platelet-derived growth factor receptor type beta in neuronal cells. Cell Signal, 25(1), 133-143. doi:10.1016/j.cellsig.2012.09.021

Kvachnina, E., Liu, G., Dityatev, A., Renner, U., Dumuis, A., Richter, D. W., Dityateva, G., Schachner, M., Voyno-Yasenetskaya, T. A., \& Ponimaskin, E. G. (2005). 5-HT7 receptor is coupled to $\mathrm{G}$ alpha subunits of heterotrimeric G12-protein to regulate gene transcription and neuronal morphology. $J$ Neurosci, 25(34), 7821-7830. doi:10.1523/JNEUROSCI.1790-05.2005 
Labasque, M., Meffre, J., Carrat, G., Becamel, C., Bockaert, J., \& Marin, P. (2010). Constitutive activity of serotonin $2 \mathrm{C}$ receptors at $\mathrm{G}$ protein-independent signaling: modulation by RNA editing and antidepressants. Mol Pharmacol, 78(5), 818-826. doi:10.1124/mol.110.066035

Labasque, M., Reiter, E., Becamel, C., Bockaert, J., \& Marin, P. (2008). Physical interaction of calmodulin with the 5-hydroxytryptamine2C receptor C-terminus is essential for $\mathrm{G}$ protein-independent, arrestin-dependent receptor signaling. Mol Biol Cell, 19(11), 4640-4650. doi:10.1091/mbc.E08-04-0422

Lecoutey, C., Hedou, D., Freret, T., Giannoni, P., Gaven, F., Since, M., Bouet, V., Ballandonne, C., Corvaisier, S., Malzert Freon, A., Mignani, S., Cresteil, T., Boulouard, M., Claeysen, S., Rochais, C., \& Dallemagne, P. (2014). Design of donecopride, a dual serotonin subtype 4 receptor agonist/acetylcholinesterase inhibitor with potential interest for Alzheimer's disease treatment. Proc Natl Acad Sci U S A, 111(36), E3825-3830. doi:10.1073/pnas.1410315111

Leonhardt, S., Herrick-Davis, K., \& Titeler, M. (1989). Detection of a novel serotonin receptor subtype (5-HT1E) in human brain: interaction with a GTP-binding protein. $J$ Neurochem, 53(2), 465-471.

Levy, F. O., Gudermann, T., Birnbaumer, M., Kaumann, A. J., \& Birnbaumer, L. (1992). Molecular cloning of a human gene (S31) encoding a novel serotonin receptor mediating inhibition of adenylyl cyclase. FEBS Lett, 296(2), 201-206.

Li, B., Zhang, S., Zhang, H., Nu, W., Cai, L., Hertz, L., \& Peng, L. (2008). Fluoxetine-mediated 5-HT2B receptor stimulation in astrocytes causes EGF receptor transactivation and ERK phosphorylation. Psychopharmacology (Berl), 201(3), 443-458. doi:10.1007/s00213-008-1306-5

Lovenberg, T. W., Baron, B. M., de Lecea, L., Miller, J. D., Prosser, R. A., Rea, M. A., Foye, P. E., Racke, M., Slone, A. L., Siegel, B. W., \& et al. (1993). A novel adenylyl cyclase- 
activating serotonin receptor (5-HT7) implicated in the regulation of mammalian circadian rhythms. Neuron, 11(3), 449-458.

Lu, C. W., Lin, T. Y., Huang, S. K., \& Wang, S. J. (2018). 5-HT1B receptor agonist CGS12066 presynaptically inhibits glutamate release in rat hippocampus. Prog Neuropsychopharmacol Biol Psychiatry, 86, 122-130. doi:10.1016/j.pnpbp.2018.05.019

Lukasiewicz, S., Blasiak, E., Faron-Gorecka, A., Polit, A., Tworzydlo, M., Gorecki, A., Wasylewski, Z., \& Dziedzicka-Wasylewska, M. (2007). Fluorescence studies of homooligomerization of adenosine A2A and serotonin 5-HT1A receptors reveal the specificity of receptor interactions in the plasma membrane. Pharmacol Rep, 59(4), 379-392.

Lukasiewicz, S., Blasiak, E., Szafran-Pilch, K., \& Dziedzicka-Wasylewska, M. (2016). Dopamine D2 and serotonin 5-HT1A receptor interaction in the context of the effects of antipsychotics - in vitro studies. $J$ Neurochem, 137(4), 549-560. doi:10.1111/jnc.13582

Magalhaes, A. C., Holmes, K. D., Dale, L. B., Comps-Agrar, L., Lee, D., Yadav, P. N., Drysdale, L., Poulter, M. O., Roth, B. L., Pin, J. P., Anisman, H., \& Ferguson, S. S. (2010). CRF receptor 1 regulates anxiety behavior via sensitization of 5-HT2 receptor signaling. Nat Neurosci, 13(5), 622-629. doi:10.1038/nn.2529

Maillet, M., Robert, S. J., Cacquevel, M., Gastineau, M., Vivien, D., Bertoglio, J., Zugaza, J. L., Fischmeister, R., \& Lezoualc'h, F. (2003). Crosstalk between Rap1 and Rac regulates secretion of sAPPalpha. Nat Cell Biol, 5(7), 633-639. doi:10.1038/ncb1007

Manivet, P., Mouillet-Richard, S., Callebert, J., Nebigil, C. G., Maroteaux, L., Hosoda, S., Kellermann, O., \& Launay, J. M. (2000). PDZ-dependent activation of nitric-oxide synthases by the serotonin 2B receptor. J Biol Chem, 275(13), 9324-9331. 
Marazziti, D., Baroni, S., Borsini, F., Picchetti, M., Vatteroni, E., Falaschi, V., \& CatenaDell'Osso, M. (2013). Serotonin receptors of type 6 (5-HT6): from neuroscience to clinical pharmacology. Curr Med Chem, 20(3), 371-377.

Maricq, A. V., Peterson, A. S., Brake, A. J., Myers, R. M., \& Julius, D. (1991). Primary structure and functional expression of the 5HT3 receptor, a serotonin-gated ion channel. Science, 254(5030), 432-437.

Marin, P., Becamel, C., Dumuis, A., \& Bockaert, J. (2012). 5-HT receptor-associated protein networks: new targets for drug discovery in psychiatric disorders? Curr Drug Targets, 13(1), 28-52.

Matthes, H., Boschert, U., Amlaiky, N., Grailhe, R., Plassat, J. L., Muscatelli, F., Mattei, M. G., \& Hen, R. (1993). Mouse 5-hydroxytryptamine5A and 5-hydroxytryptamine5B receptors define a new family of serotonin receptors: cloning, functional expression, and chromosomal localization. Mol Pharmacol, 43(3), 313-319.

Matthys, A., Haegeman, G., Van Craenenbroeck, K., \& Vanhoenacker, P. (2011). Role of the 5-HT7 receptor in the central nervous system: from current status to future perspectives. Mol Neurobiol, 43(3), 228-253. doi:10.1007/s12035-011-8175-3

Matthys, A., Van Craenenbroeck, K., Lintermans, B., Haegeman, G., \& Vanhoenacker, P. (2012). RhoBTB3 interacts with the 5-HT7a receptor and inhibits its proteasomal degradation. Cell Signal, 24(5), 1053-1063. doi:10.1016/j.cellsig.2011.12.027

McCorvy, J. D., \& Roth, B. L. (2015). Structure and function of serotonin G protein-coupled receptors. Pharmacol Ther, 150, 129-142. doi:10.1016/j.pharmthera.2015.01.009

McGrew, L., Price, R. D., Hackler, E., Chang, M. S., \& Sanders-Bush, E. (2004). RNA editing of the human serotonin 5-HT2C receptor disrupts transactivation of the small G-protein RhoA. Mol Pharmacol, 65(1), 252-256. doi:10.1124/mol.65.1.252

McLean, S. L., Woolley, M. L., Thomas, D., \& Neill, J. C. (2009). Role of 5-HT receptor mechanisms in sub-chronic PCP-induced reversal learning deficits in the rat. Psychopharmacology (Berl), 206(3), 403-414. doi:10.1007/s00213-009-1618-0 
Meffre, J., Chaumont-Dubel, S., Mannoury la Cour, C., Loiseau, F., Watson, D. J., Dekeyne, A., Seveno, M., Rivet, J. M., Gaven, F., Deleris, P., Herve, D., Fone, K. C., Bockaert, J., Millan, M. J., \& Marin, P. (2012). 5-HT(6) receptor recruitment of mTOR as a mechanism for perturbed cognition in schizophrenia. EMBO Mol Med, 4(10), 10431056. doi:10.1002/emmm.201201410

Meschin, P., Demion, M., Cazorla, O., Finan, A., Thireau, J., Richard, S., \& Lacampagne, A. (2015). p11 modulates calcium handling through 5-HT(4)R pathway in rat ventricular cardiomyocytes. Cell Calcium, 58(6), 549-557. doi:10.1016/j.ceca.2015.08.005

Meyerhof, W., Obermuller, F., Fehr, S., \& Richter, D. (1993). A novel rat serotonin receptor: primary structure, pharmacology, and expression pattern in distinct brain regions. DNA Cell Biol, 12(5), 401-409. doi:10.1089/dna.1993.12.401

Mi, Z., Si, T., Kapadia, K., Li, Q., \& Muma, N. A. (2017). Receptor-stimulated transamidation induces activation of $\mathrm{Rac1}$ and $\mathrm{Cdc} 42$ and the regulation of dendritic spines. Neuropharmacology, 117, 93-105. doi:10.1016/j.neuropharm.2017.01.034

Middlemiss, D. N., \& Fozard, J. R. (1983). 8-Hydroxy-2-(di-n-propylamino)-tetralin discriminates between subtypes of the 5-HT1 recognition site. Eur J Pharmacol, 90(1), $151-153$

Millon, C., Flores-Burgess, A., Narvaez, M., Borroto-Escuela, D. O., Santin, L., Gago, B., Narvaez, J. A., Fuxe, K., \& Diaz-Cabiale, Z. (2016). Galanin (1-15) enhances the antidepressant effects of the 5-HT1A receptor agonist 8-OH-DPAT: involvement of the raphe-hippocampal 5-HT neuron system. Brain Struct Funct, 221(9), 4491-4504. doi:10.1007/s00429-015-1180-y

Mlinar, B., Montalbano, A., Waider, J., Lesch, K. P., \& Corradetti, R. (2017). Increased functional coupling of 5-HT1A autoreceptors to GIRK channels in Tph2(-/-) mice. Eur Neuropsychopharmacol, 27(12), 1258-1267. doi:10.1016/j.euroneuro.2017.10.033 
Monsma, F. J., Jr., Shen, Y., Ward, R. P., Hamblin, M. W., \& Sibley, D. R. (1993). Cloning and expression of a novel serotonin receptor with high affinity for tricyclic psychotropic drugs. Mol Pharmacol, 43(3), 320-327.

Montanez, S., Munn, J. L., Owens, W. A., Horton, R. E., \& Daws, L. C. (2014). 5-HT1B receptor modulation of the serotonin transporter in vivo: studies using $\mathrm{KO}$ mice. Neurochem Int, 73, 127-131. doi:10.1016/j.neuint.2013.11.004

Moreno, J. L., Holloway, T., Albizu, L., Sealfon, S. C., \& Gonzalez-Maeso, J. (2011). Metabotropic glutamate mGlu2 receptor is necessary for the pharmacological and behavioral effects induced by hallucinogenic 5-HT2A receptor agonists. Neurosci Lett, 493(3), 76-79. doi:10.1016/j.neulet.2011.01.046

Moutkine, I., Quentin, E., Guiard, B. P., Maroteaux, L., \& Doly, S. (2017). Heterodimers of serotonin receptor subtypes 2 are driven by 5-HT2C protomers. J Biol Chem, 292(15), 6352-6368. doi:10.1074/jbc.M117.779041

Mullard, A. (2016). Symptomatic AD treatment fails in first phase III. Nat Rev Drug Discov, 15(11), 738. doi:10.1038/nrd.2016.225

Munoz-Islas, E., Vidal-Cantu, G. C., Bravo-Hernandez, M., Cervantes-Duran, C., QuinonezBastidas, G. N., Pineda-Farias, J. B., Barragan-Iglesias, P., \& Granados-Soto, V. (2014). Spinal 5-HT(5)A receptors mediate 5-HT-induced antinociception in several pain models in rats. Pharmacol Biochem Behav, 120, 25-32. doi:10.1016/j.pbb.2014.02.001

Murat, S., Bigot, M., Chapron, J., Konig, G. M., Kostenis, E., Battaglia, G., Nicoletti, F., Bourinet, E., Bockaert, J., Marin, P., \& Vandermoere, F. (2018). 5-HT2A receptordependent phosphorylation of mGlu2 receptor at Serine 843 promotes mGlu2 receptoroperated Gi/o signaling. Mol Psychiatry. doi:10.1038/s41380-018-0069-6

Narla, C., Dunn, H. A., Ferguson, S. S., \& Poulter, M. O. (2015). Suppression of piriform cortex activity in rat by corticotropin-releasing factor 1 and serotonin $2 \mathrm{~A} / \mathrm{C}$ receptors. Front Cell Neurosci, 9, 200. doi:10.3389/fncel.2015.00200 
Nebigil, C. G., Launay, J. M., Hickel, P., Tournois, C., \& Maroteaux, L. (2000). 5hydroxytryptamine $2 \mathrm{~B}$ receptor regulates cell-cycle progression: cross-talk with tyrosine kinase pathways. Proc Natl Acad Sci U S A, 97(6), 2591-2596. doi:10.1073/pnas.050282397

Nelson, C. S., Cone, R. D., Robbins, L. S., Allen, C. N., \& Adelman, J. P. (1995). Cloning and expression of a 5HT7 receptor from Xenopus laevis. Receptors Channels, 3(1), 61-70.

Neumaier, J. F., Sexton, T. J., Yracheta, J., Diaz, A. M., \& Brownfield, M. (2001). Localization of 5-HT(7) receptors in rat brain by immunocytochemistry, in situ hybridization, and agonist stimulated cFos expression. J Chem Neuroanat, 21(1), 63-73.

Niesler, B., Kapeller, J., Hammer, C., \& Rappold, G. (2008). Serotonin type 3 receptor genes: HTR3A, B, C, D, E. Pharmacogenomics, 9(5), 501-504. doi:10.2217/14622416.9.5.501

Nikiforuk, A., Holuj, M., Kos, T., \& Popik, P. (2016). The effects of a 5-HT5A receptor antagonist in a ketamine-based rat model of cognitive dysfunction and the negative symptoms of schizophrenia. Neuropharmacology, 105, 351-360. doi:10.1016/j.neuropharm.2016.01.035

Nikiforuk, A., Kos, T., Fijal, K., Holuj, M., Rafa, D., \& Popik, P. (2013). Effects of the selective 5-HT7 receptor antagonist SB-269970 and amisulpride on ketamine-induced schizophrenia-like deficits in rats. PLoS One, 8(6), e66695. doi:10.1371/journal.pone.0066695

Niswender, C. M., Copeland, S. C., Herrick-Davis, K., Emeson, R. B., \& Sanders-Bush, E. (1999). RNA editing of the human serotonin 5-hydroxytryptamine 2C receptor silences constitutive activity. J Biol Chem, 274(14), 9472-9478.

Noda, M., Yasuda, S., Okada, M., Higashida, H., Shimada, A., Iwata, N., Ozaki, N., Nishikawa, K., Shirasawa, S., Uchida, M., Aoki, S., \& Wada, K. (2003). Recombinant human serotonin 5A receptors stably expressed in C6 glioma cells couple to multiple signal transduction pathways. J Neurochem, 84(2), 222-232. 
Norum, J. H., Hart, K., \& Levy, F. O. (2003). Ras-dependent ERK activation by the human G(s)-coupled serotonin receptors 5-HT4(b) and 5-HT7(a). J Biol Chem, 278(5), 30983104. doi:10.1074/jbc.M206237200

Norum, J. H., Methi, T., Mattingly, R. R., \& Levy, F. O. (2005). Endogenous expression and protein kinase A-dependent phosphorylation of the guanine nucleotide exchange factor Ras-GRF1 in human embryonic kidney 293 cells. FEBS J, 272(9), 2304-2316. doi:10.1111/j.1742-4658.2005.04658.x

Oufkir, T., Arseneault, M., Sanderson, J. T., \& Vaillancourt, C. (2010). The 5-HT 2A serotonin receptor enhances cell viability, affects cell cycle progression and activates MEKERK1/2 and JAK2-STAT3 signalling pathways in human choriocarcinoma cell lines. Placenta, 31(5), 439-447. doi:10.1016/j.placenta.2010.02.019

Oufkir, T., \& Vaillancourt, C. (2011). Phosphorylation of JAK2 by serotonin 5-HT (2A) receptor activates both STAT3 and ERK1/2 pathways and increases growth of JEG-3 human placental choriocarcinoma cell. Placenta, 32(12), 1033-1040. doi:10.1016/j.placenta.2011.09.005

Parker, L. L., Backstrom, J. R., Sanders-Bush, E., \& Shieh, B. H. (2003). Agonist-induced phosphorylation of the serotonin 5-HT2C receptor regulates its interaction with multiple PDZ protein 1. J Biol Chem, 278(24), 21576-21583.

Pedigo, N. W., Yamamura, H. I., \& Nelson, D. L. (1981). Discrimination of multiple [3H]5hydroxytryptamine binding sites by the neuroleptic spiperone in rat brain. $J$ Neurochem, $36(1), 220-226$.

Pellissier, L. P., Barthet, G., Gaven, F., Cassier, E., Trinquet, E., Pin, J. P., Marin, P., Dumuis, A., Bockaert, J., Baneres, J. L., \& Claeysen, S. (2011). G protein activation by serotonin type 4 receptor dimers: evidence that turning on two protomers is more efficient. J Biol Chem, 286(12), 9985-9997. doi:10.1074/jbc.M110.201939

Peng, Y., McCorvy, J. D., Harpsoe, K., Lansu, K., Yuan, S., Popov, P., Qu, L., Pu, M., Che, T., Nikolajsen, L. F., Huang, X. P., Wu, Y., Shen, L., Bjorn-Yoshimoto, W. E., Ding, K., 
Wacker, D., Han, G. W., Cheng, J., Katritch, V., Jensen, A. A., Hanson, M. A., Zhao, S., Gloriam, D. E., Roth, B. L., Stevens, R. C., \& Liu, Z. J. (2018). 5-HT2C Receptor Structures Reveal the Structural Basis of GPCR Polypharmacology. Cell, 172(4), 719730 e714. doi:10.1016/j.cell.2018.01.001

Peroutka, S. J., Lebovitz, R. M., \& Snyder, S. H. (1979). Serotonin receptor binding sites affected differentially by guanine nucleotides. Mol Pharmacol, 16(3), 700-708.

Peroutka, S. J., Lebovitz, R. M., \& Snyder, S. H. (1981). Two distinct central serotonin receptors with different physiological functions. Science, 212(4496), 827-829.

Peroutka, S. J., \& Snyder, S. H. (1979). Multiple serotonin receptors: differential binding of $[3 \mathrm{H}] 5$-hydroxytryptamine, $[3 \mathrm{H}]$ lysergic acid diethylamide and $[3 \mathrm{H}]$ spiroperidol. $\mathrm{Mol}$ Pharmacol, 16(3), 687-699.

Pichon, X., Wattiez, A. S., Becamel, C., Ehrlich, I., Bockaert, J., Eschalier, A., Marin, P., \& Courteix, C. (2010). Disrupting 5-HT(2A) receptor/PDZ protein interactions reduces hyperalgesia and enhances SSRI efficacy in neuropathic pain. Mol Ther, 18(8), 14621470. doi:10.1038/mt.2010.101

Pindon, A., van Hecke, G., van Gompel, P., Lesage, A. S., Leysen, J. E., \& Jurzak, M. (2002). Differences in signal transduction of two 5-HT4 receptor splice variants: compound specificity and dual coupling with Galphas- and Galphai/o-proteins. Mol Pharmacol, 61(1), 85-96.

Plassat, J. L., Amlaiky, N., \& Hen, R. (1993). Molecular cloning of a mammalian serotonin receptor that activates adenylate cyclase. Mol Pharmacol, 44(2), 229-236.

Plassat, J. L., Boschert, U., Amlaiky, N., \& Hen, R. (1992). The mouse 5HT5 receptor reveals a remarkable heterogeneity within the 5HT1D receptor family. EMBO J, 11(13), 47794786.

Polter, A. M., \& Li, X. (2010). 5-HT1A receptor-regulated signal transduction pathways in brain. Cell Signal, 22(10), 1406-1412. doi:10.1016/j.cellsig.2010.03.019 
Ponimaskin, E. G., Profirovic, J., Vaiskunaite, R., Richter, D. W., \& Voyno-Yasenetskaya, T. A. (2002). 5-Hydroxytryptamine 4(a) receptor is coupled to the Galpha subunit of heterotrimeric G13 protein. J Biol Chem, 277(23), 20812-20819. doi:10.1074/jbc.M112216200

Quinn, J. C., Johnson-Farley, N. N., Yoon, J., \& Cowen, D. S. (2002). Activation of extracellular-regulated kinase by 5-hydroxytryptamine(2A) receptors in PC12 cells is protein kinase $\mathrm{C}$-independent and requires calmodulin and tyrosine kinases. $J$ Pharmacol Exp Ther, 303(2), 746-752. doi:10.1124/jpet.102.038083

Rasmussen, S. G., DeVree, B. T., Zou, Y., Kruse, A. C., Chung, K. Y., Kobilka, T. S., Thian, F. S., Chae, P. S., Pardon, E., Calinski, D., Mathiesen, J. M., Shah, S. T., Lyons, J. A., Caffrey, M., Gellman, S. H., Steyaert, J., Skiniotis, G., Weis, W. I., Sunahara, R. K., \& Kobilka, B. K. (2011). Crystal structure of the beta2 adrenergic receptor-Gs protein complex. Nature, 477(7366), 549-555. doi:10.1038/nature10361

Raymond, J. R., Mukhin, Y. V., Gelasco, A., Turner, J., Collinsworth, G., Gettys, T. W., Grewal, J. S., \& Garnovskaya, M. N. (2001). Multiplicity of mechanisms of serotonin receptor signal transduction. Pharmacol Ther, 92(2-3), 179-212.

Raymond, J. R., Mukhin, Y. V., Gettys, T. W., \& Garnovskaya, M. N. (1999). The recombinant 5-HT1A receptor: G protein coupling and signalling pathways. Br J Pharmacol, 127(8), 1751-1764. doi:10.1038/sj.bjp.0702723

Renner, U., Zeug, A., Woehler, A., Niebert, M., Dityatev, A., Dityateva, G., Gorinski, N., Guseva, D., Abdel-Galil, D., Frohlich, M., Doring, F., Wischmeyer, E., Richter, D. W., Neher, E., \& Ponimaskin, E. G. (2012). Heterodimerization of serotonin receptors 5HT1A and 5-HT7 differentially regulates receptor signalling and trafficking. J Cell Sci, 125(Pt 10), 2486-2499. doi:10.1242/jcs.101337

Robertson, D. N., Johnson, M. S., Moggach, L. O., Holland, P. J., Lutz, E. M., \& Mitchell, R. (2003). Selective interaction of ARF1 with the carboxy-terminal tail domain of the 5HT2A receptor. Mol Pharmacol, 64(5), 1239-1250. 
Rochais, C., Lecoutey, C., Gaven, F., Giannoni, P., Hamidouche, K., Hedou, D., Dubost, E., Genest, D., Yahiaoui, S., Freret, T., Bouet, V., Dauphin, F., Sopkova de Oliveira Santos, J., Ballandonne, C., Corvaisier, S., Malzert-Freon, A., Legay, R., Boulouard, M., Claeysen, S., \& Dallemagne, P. (2015). Novel multitarget-directed ligands (MTDLs) with acetylcholinesterase (AChE) inhibitory and serotonergic subtype 4 receptor (5HT4R) agonist activities as potential agents against Alzheimer's disease: the design of donecopride. J Med Chem, 58(7), 3172-3187. doi:10.1021/acs.jmedchem.5b00115

Rogers, S. M., \& Ott, S. R. (2015). Differential activation of serotonergic neurons during shortand long-term gregarization of desert locusts. Proc Biol Sci, 282(1800), 20142062. doi:10.1098/rspb.2014.2062

Roth, B. L. (2007). Drugs and valvular heart disease. $N$ Engl J Med, 356(1), 6-9. doi:10.1056/NEJMp068265

Ruat, M., Traiffort, E., Arrang, J. M., Tardivel-Lacombe, J., Diaz, J., Leurs, R., \& Schwartz, J. C. (1993). A novel rat serotonin (5-HT6) receptor: molecular cloning, localization and stimulation of cAMP accumulation. Biochem Biophys Res Commun, 193(1), 268-276.

Ruat, M., Traiffort, E., Leurs, R., Tardivel-Lacombe, J., Diaz, J., Arrang, J. M., \& Schwartz, J. C. (1993). Molecular cloning, characterization, and localization of a high-affinity serotonin receptor (5-HT7) activating cAMP formation. Proc Natl Acad Sci U S A, $90(18), 8547-8551$.

Schechter, L. E., Lin, Q., Smith, D. L., Zhang, G., Shan, Q., Platt, B., Brandt, M. R., Dawson, L. A., Cole, D., Bernotas, R., Robichaud, A., Rosenzweig-Lipson, S., \& Beyer, C. E. (2008). Neuropharmacological profile of novel and selective 5-HT6 receptor agonists: WAY-181187 and WAY-208466. Neuropsychopharmacology, 33(6), 1323-1335. doi:10.1038/sj.npp.1301503

Schellekens, H., De Francesco, P. N., Kandil, D., Theeuwes, W. F., McCarthy, T., van Oeffelen, W. E., Perello, M., Giblin, L., Dinan, T. G., \& Cryan, J. F. (2015). Ghrelin's Orexigenic 
Effect Is Modulated via a Serotonin 2C Receptor Interaction. ACS Chem Neurosci, 6(7), 1186-1197. doi:10.1021/cn500318q

Schlenstedt, J., Balfanz, S., Baumann, A., \& Blenau, W. (2006). Am5-HT7: molecular and pharmacological characterization of the first serotonin receptor of the honeybee (Apis mellifera). J Neurochem, 98(6), 1985-1998. doi:10.1111/j.1471-4159.2006.04012.x

Schmid, C. L., \& Bohn, L. M. (2010). Serotonin, but not N-methyltryptamines, activates the serotonin $2 \mathrm{~A}$ receptor via a ss-arrestin2/Src/Akt signaling complex in vivo. $J$ Neurosci, 30(40), 13513-13524. doi:10.1523/JNEUROSCI.1665-10.2010

Schmid, C. L., Raehal, K. M., \& Bohn, L. M. (2008). Agonist-directed signaling of the serotonin 2A receptor depends on beta-arrestin-2 interactions in vivo. Proc Natl Acad Sci U S A, 105(3), 1079-1084. doi:10.1073/pnas.0708862105

Schoeffter, P., \& Hoyer, D. (1989). 5-Hydroxytryptamine 5-HT1B and 5-HT1D receptors mediating inhibition of adenylate cyclase activity. Pharmacological comparison with special reference to the effects of yohimbine, rauwolscine and some beta-adrenoceptor antagonists. Naunyn Schmiedebergs Arch Pharmacol, 340(3), 285-292.

Sebben, M., Ansanay, H., Bockaert, J., \& Dumuis, A. (1994). 5-HT6 receptors positively coupled to adenylyl cyclase in striatal neurones in culture. Neuroreport, 5(18), 25532557.

Sheffler, D. J., Kroeze, W. K., Garcia, B. G., Deutch, A. Y., Hufeisen, S. J., Leahy, P., Bruning, J. C., \& Roth, B. L. (2006). p90 ribosomal S6 kinase 2 exerts a tonic brake on G proteincoupled receptor signaling. Proc Natl Acad Sci U S A, 103(12), 4717-4722.

Shenker, A., Maayani, S., Weinstein, H., \& Green, J. P. (1987). Pharmacological characterization of two 5-hydroxytryptamine receptors coupled to adenylate cyclase in guinea pig hippocampal membranes. Mol Pharmacol, 31(4), 357-367.

Shum, J. K., Melendez, J. A., \& Jeffrey, J. J. (2002). Serotonin-induced MMP-13 production is mediated via phospholipase $\mathrm{C}$, protein kinase $\mathrm{C}$, and ERK1/2 in rat uterine smooth muscle cells. J Biol Chem, 277(45), 42830-42840. doi:10.1074/jbc.M205094200 
Singh, R. K., Jia, C., Garcia, F., Carrasco, G. A., Battaglia, G., \& Muma, N. A. (2010). Activation of the JAK-STAT pathway by olanzapine is necessary for desensitization of serotonin2A receptor-stimulated phospholipase $\mathrm{C}$ signaling in rat frontal cortex but not serotonin2A receptor-stimulated hormone release. J Psychopharmacol, 24(7), 10791088. doi:10.1177/0269881109103090

Sokolina, K., Kittanakom, S., Snider, J., Kotlyar, M., Maurice, P., Gandia, J., BenleulmiChaachoua, A., Tadagaki, K., Oishi, A., Wong, V., Malty, R. H., Deineko, V., Aoki, H., Amin, S., Yao, Z., Morato, X., Otasek, D., Kobayashi, H., Menendez, J., Auerbach, D., Angers, S., Przulj, N., Bouvier, M., Babu, M., Ciruela, F., Jockers, R., Jurisica, I., \& Stagljar, I. (2017). Systematic protein-protein interaction mapping for clinically relevant human GPCRs. Mol Syst Biol, 13(3), 918. doi:10.15252/msb.20167430

Speranza, L., Labus, J., Volpicelli, F., Guseva, D., Lacivita, E., Leopoldo, M., Bellenchi, G. C., di Porzio, U., Bijata, M., Perrone-Capano, C., \& Ponimaskin, E. (2017). Serotonin 5HT7 receptor increases the density of dendritic spines and facilitates synaptogenesis in forebrain neurons. J Neurochem, 141(5), 647-661. doi:10.1111/jnc.13962

Stroth, N., \& Svenningsson, P. (2015). S100B interacts with the serotonin 5-HT7 receptor to regulate a depressive-like behavior. Eur Neuropsychopharmacol, 25(12), 2372-2380. doi:10.1016/j.euroneuro.2015.10.003

Sui, H., Xu, H., Ji, Q., Liu, X., Zhou, L., Song, H., Zhou, X., Xu, Y., Chen, Z., Cai, J., Ji, G., \& Li, Q. (2015). 5-hydroxytryptamine receptor (5-HT1DR) promotes colorectal cancer metastasis by regulating Axin1/beta-catenin/MMP-7 signaling pathway. Oncotarget, 6(28), 25975-25987. doi:10.18632/oncotarget.4543

Svenningsson, P., Chergui, K., Rachleff, I., Flajolet, M., Zhang, X., Yacoubi, M. E., Vaugeois, J. M., Nomikos, G. G., \& Greengard, P. (2006). Alterations in 5-HT1B receptor function by 111 in depression-like states. Science, 311(5757), 77-80. 
Svenningsson, P., Tzavara, E. T., Liu, F., Fienberg, A. A., Nomikos, G. G., \& Greengard, P. (2002). DARPP-32 mediates serotonergic neurotransmission in the forebrain. Proc Natl Acad Sci U S A, 99(5), 3188-3193. doi:10.1073/pnas.052712699

Svenningsson, P., Tzavara, E. T., Qi, H., Carruthers, R., Witkin, J. M., Nomikos, G. G., \& Greengard, P. (2007). Biochemical and behavioral evidence for antidepressant-like effects of 5-HT6 receptor stimulation. $J$ Neurosci, 27(15), 4201-4209. doi:10.1523/JNEUROSCI.3110-06.2007

Teitler, M., \& Klein, M. T. (2012). A new approach for studying GPCR dimers: drug-induced inactivation and reactivation to reveal GPCR dimer function in vitro, in primary culture, and in vivo. Pharmacol Ther, 133(2), 205-217. doi:10.1016/j.pharmthera.2011.10.007

Temkin, P., Lauffer, B., Jager, S., Cimermancic, P., Krogan, N. J., \& von Zastrow, M. (2011). SNX27 mediates retromer tubule entry and endosome-to-plasma membrane trafficking of signalling receptors. Nat Cell Biol, 13(6), 715-721. doi:10.1038/ncb2252

Tena-Campos, M., Ramon, E., Borroto-Escuela, D. O., Fuxe, K., \& Garriga, P. (2015). The zinc binding receptor GPR39 interacts with 5-HT1A and GalR1 to form dynamic heteroreceptor complexes with signaling diversity. Biochim Biophys Acta, 1852(12), 2585-2592. doi:10.1016/j.bbadis.2015.09.003

Thomas, D. R., Atkinson, P. J., Ho, M., Bromidge, S. M., Lovell, P. J., Villani, A. J., Hagan, J. J., Middlemiss, D. N., \& Price, G. W. (2000). [(3)H]-SB-269970--A selective antagonist radioligand for 5-HT(7) receptors. $\mathrm{Br} \quad J$ Pharmacol, 130(2), 409-417. doi:10.1038/sj.bjp.0703318

Thomas, G. M., Rumbaugh, G. R., Harrar, D. B., \& Huganir, R. L. (2005). Ribosomal S6 kinase 2 interacts with and phosphorylates PDZ domain-containing proteins and regulates AMPA receptor transmission. Proc Natl Acad Sci U S A, 102(42), 15006-15011.

Tonini, M., Vicini, R., Cervio, E., De Ponti, F., De Giorgio, R., Barbara, G., Stanghellini, V., Dellabianca, A., \& Sternini, C. (2005). 5-HT7 receptors modulate peristalsis and 
accommodation in the guinea pig ileum. Gastroenterology, 129(5), 1557-1566. doi:10.1053/j.gastro.2005.08.005

Tournois, C., Mutel, V., Manivet, P., Launay, J. M., \& Kellermann, O. (1998). Cross-talk between 5-hydroxytryptamine receptors in a serotonergic cell line. Involvement of arachidonic acid metabolism. J Biol Chem, 273(28), 17498-17503.

Tsou, A. P., Kosaka, A., Bach, C., Zuppan, P., Yee, C., Tom, L., Alvarez, R., Ramsey, S., Bonhaus, D. W., Stefanich, E., \& et al. (1994). Cloning and expression of a 5hydroxytryptamine7 receptor positively coupled to adenylyl cyclase. $J$ Neurochem, 63(2), 456-464.

Tsuchioka, M., Takebayashi, M., Hisaoka, K., Maeda, N., \& Nakata, Y. (2008). Serotonin (5HT) induces glial cell line-derived neurotrophic factor (GDNF) mRNA expression via the transactivation of fibroblast growth factor receptor 2 (FGFR2) in rat C6 glioma cells. J Neurochem, 106(1), 244-257. doi:JNC5357 [pii]

$10.1111 / \mathrm{j} .1471-4159.2008 .05357 . \mathrm{x}$

Turner, J. H., Garnovskaya, M. N., \& Raymond, J. R. (2007). Serotonin 5-HT1A receptor stimulates c-Jun N-terminal kinase and induces apoptosis in Chinese hamster ovary fibroblasts. Biochim Biophys Acta, 1773(3), 391-399. doi:10.1016/j.bbamcr.2006.12.003

Turner, J. H., Gelasco, A. K., \& Raymond, J. R. (2004). Calmodulin interacts with the third intracellular loop of the serotonin 5-hydroxytryptamine1A receptor at two distinct sites: putative role in receptor phosphorylation by protein kinase C. J Biol Chem, 279(17), 17027-17037. doi:10.1074/jbc.M313919200

Turner, J. H., \& Raymond, J. R. (2005). Interaction of calmodulin with the serotonin 5hydroxytryptamine $2 \mathrm{~A}$ receptor. A putative regulator of $\mathrm{G}$ protein coupling and receptor phosphorylation by protein kinase C. J Biol Chem, 280(35), 30741-30750. doi:10.1074/jbc.M501696200 
Ullmer, C., Schmuck, K., Figge, A., \& Lubbert, H. (1998). Cloning and characterization of MUPP1, a novel PDZ domain protein. FEBS Lett, 424(1-2), 63-68.

Varnas, K., Thomas, D. R., Tupala, E., Tiihonen, J., \& Hall, H. (2004). Distribution of 5-HT7 receptors in the human brain: a preliminary autoradiographic study using [3H]SB269970. Neurosci Lett, 367(3), 313-316. doi:10.1016/j.neulet.2004.06.025

Vinals, X., Moreno, E., Lanfumey, L., Cordomi, A., Pastor, A., de La Torre, R., Gasperini, P., Navarro, G., Howell, L. A., Pardo, L., Lluis, C., Canela, E. I., McCormick, P. J., Maldonado, R., \& Robledo, P. (2015). Cognitive Impairment Induced by Delta9tetrahydrocannabinol Occurs through Heteromers between Cannabinoid CB1 and Serotonin 5-HT2A Receptors. PLoS Biol, 13(7), e1002194. doi:10.1371/journal.pbio.1002194

Vogrig, A., Dorr, L., Bouzidi, N., Boucherle, B., Wattiez, A. S., Cassier, E., Vallon, G., Ripoche, I., Abrunhosa-Thomas, I., Marin, P., Nauton, L., Thery, V., Courteix, C., Lian, L. Y., \& Ducki, S. (2013). Structure-based design of PDZ ligands as inhibitors of 5HT(2A) receptor/PSD-95 PDZ1 domain interaction possessing anti-hyperalgesic activity. ACS Chem Biol, 8(10), 2209-2216. doi:10.1021/cb400308u

Wacker, D., Wang, C., Katritch, V., Han, G. W., Huang, X. P., Vardy, E., McCorvy, J. D., Jiang, Y., Chu, M., Siu, F. Y., Liu, W., Xu, H. E., Cherezov, V., Roth, B. L., \& Stevens, R. C. (2013). Structural features for functional selectivity at serotonin receptors. Science, 340(6132), 615-619. doi:10.1126/science.1232808

Wacker, D., Wang, S., McCorvy, J. D., Betz, R. M., Venkatakrishnan, A. J., Levit, A., Lansu, K., Schools, Z. L., Che, T., Nichols, D. E., Shoichet, B. K., Dror, R. O., \& Roth, B. L. (2017). Crystal Structure of an LSD-Bound Human Serotonin Receptor. Cell, 168(3), 377-389 e312. doi:10.1016/j.cell.2016.12.033

Waeber, C., Hoyer, D., \& Palacios, J. M. (1989). 5-hydroxytryptamine3 receptors in the human brain: autoradiographic visualization using [3H]ICS 205-930. Neuroscience, 31(2), $393-400$. 
Waeber, C., \& Moskowitz, M. A. (1995). [3H]sumatriptan labels both 5-HT1D and 5-HT1F receptor binding sites in the guinea pig brain: an autoradiographic study. Naunyn Schmiedebergs Arch Pharmacol, 352(3), 263-275.

Walther, C., Caetano, F. A., Dunn, H. A., \& Ferguson, S. S. (2015). PDZK1/NHERF3 differentially regulates corticotropin-releasing factor receptor 1 and serotonin $2 \mathrm{~A}$ receptor signaling and endocytosis. Cell Signal, 27(3), 519-531. doi:10.1016/j.cellsig.2014.12.019

Wang, C., Jiang, Y., Ma, J., Wu, H., Wacker, D., Katritch, V., Han, G. W., Liu, W., Huang, X. P., Vardy, E., McCorvy, J. D., Gao, X., Zhou, X. E., Melcher, K., Zhang, C., Bai, F., Yang, H., Yang, L., Jiang, H., Roth, B. L., Cherezov, V., Stevens, R. C., \& Xu, H. E. (2013). Structural basis for molecular recognition at serotonin receptors. Science, 340(6132), 610-614. doi:10.1126/science.1232807

Wang, H., Huang, Z., Huang, L., Niu, S., Rao, X., Xu, J., Kong, H., Yang, J., Yang, C., Wu, D., Li, S., Li, X. J., Liu, T., \& Sheng, G. (2012). Hypothalamic Ahil mediates feeding behavior through interaction with 5-HT2C receptor. J Biol Chem, 287(3), 2237-2246. doi:10.1074/jbc.M111.277871

Wang, L., Lv, Y., Deng, W., Peng, X., Xiao, Z., Xi, Z., Chen, G., \& Wang, X. (2015). 5-HT6 Receptor Recruitment of mTOR Modulates Seizure Activity in Epilepsy. Mol Neurobiol, 51(3), 1292-1299. doi:10.1007/s12035-014-8806-6

Warner-Schmidt, J. L., Flajolet, M., Maller, A., Chen, E. Y., Qi, H., Svenningsson, P., \& Greengard, P. (2009). Role of p11 in cellular and behavioral effects of 5-HT4 receptor stimulation. J Neurosci, 29(6), 1937-1946. doi:10.1523/JNEUROSCI.5343-08.2009

Weiss, S., Sebben, M., Kemp, D. E., \& Bockaert, J. (1986). Serotonin 5-HT1 receptors mediate inhibition of cyclic AMP production in neurons. Eur J Pharmacol, 120(2), 227-230.

Xia, Z., Gray, J. A., Compton-Toth, B. A., \& Roth, B. L. (2003). A direct interaction of PSD95 with 5-HT2A serotonin receptors regulates receptor trafficking and signal transduction. J Biol Chem, 278(24), 21901-21908. doi:10.1074/jbc.M301905200 
Xia, Z., Hufeisen, S. J., Gray, J. A., \& Roth, B. L. (2003). The PDZ-binding domain is essential for the dendritic targeting of 5-HT2A serotonin receptors in cortical pyramidal neurons in vitro. Neuroscience, 122(4), 907-920.

Xiao, H., Hapiak, V. M., Smith, K. A., Lin, L., Hobson, R. J., Plenefisch, J., \& Komuniecki, R. (2006). SER-1, a Caenorhabditis elegans 5-HT2-like receptor, and a multi-PDZ domain containing protein (MPZ-1) interact in vulval muscle to facilitate serotonin-stimulated egg-laying. Dev Biol, 298(2), 379-391. doi:10.1016/j.ydbio.2006.06.044

Yamazaki, M., Harada, K., Yamamoto, N., Yarimizu, J., Okabe, M., Shimada, T., Ni, K., \& Matsuoka, N. (2014). ASP5736, a novel 5-HT5A receptor antagonist, ameliorates positive symptoms and cognitive impairment in animal models of schizophrenia. Eur Neuropsychopharmacol, 24(10), 1698-1708. doi:10.1016/j.euroneuro.2014.07.009

Yuen, E. Y., Jiang, Q., Chen, P., Feng, J., \& Yan, Z. (2008). Activation of 5-HT2A/C receptors counteracts 5-HT1A regulation of n-methyl-D-aspartate receptor channels in pyramidal neurons of prefrontal cortex. J Biol Chem, 283(25), 17194-17204. doi:10.1074/jbc.M801713200

Yun, H. M., Baik, J. H., Kang, I., Jin, C., \& Rhim, H. (2010). Physical interaction of Jab1 with human serotonin 6 G-protein-coupled receptor and their possible roles in cell survival. J Biol Chem, 285(13), 10016-10029. doi:10.1074/jbc.M109.068759

Yun, H. M., Kim, S., Kim, H. J., Kostenis, E., Kim, J. I., Seong, J. Y., Baik, J. H., \& Rhim, H. (2007). The novel cellular mechanism of human 5-HT6 receptor through an interaction with Fyn. J Biol Chem, 282(8), 5496-5505. doi:10.1074/jbc.M606215200

Zhang, X., Andren, P. E., Greengard, P., \& Svenningsson, P. (2008). Evidence for a role of the 5-HT1B receptor and its adaptor protein, p11, in L-DOPA treatment of an animal model of Parkinsonism. Proc Natl Acad Sci $U$ S A, 105(6), 2163-2168. doi:10.1073/pnas.0711839105

\section{Figure legends}




\section{Figure 1. Classification of serotonin receptors: an historic view}

The evolution of 5-HT receptor classification from the first proposal made by Gaddum and Picarelli to the current consensus is depicted. During the "Pharmacological Period", 8 receptor subtypes have been characterized. During the "Molecular Biology Period", 17 genes (designated as HTRs) and one pseudogene (designated as Htr) have been cloned, leading to the current classification of 17 functional 5-HT receptors.

\section{Figure 2. Solved structures of 5-HT receptors}

Comparison of the overall architecture of 5- $\mathrm{HT}_{1 \mathrm{~B}}(\mathrm{~A}), 5-\mathrm{HT}_{2 \mathrm{~B}}(\mathrm{~B})$ and $5-\mathrm{HT}_{2} \mathrm{C}$ receptors $(\mathrm{C}$ and D) bound to the agonist ergotamine (ERG) or the inverse agonist ritanserin (RIT). The limits of the classical orthosteric site are indicated using dashed lines: upper limit in blue, lower limit in pink.

\section{Figure 3. Gene structures of human 5-HT receptor coding sequences}

This figure was generated using released data of the human genome project available on the NCBI site (http://www.ncbi.nlm.nih.gov) using Gene Database and Consensus CDS Reference Sequences. GRCh38.p12 assembly was used to localize the exons except for $\operatorname{Htr}_{5 \mathrm{~B}}$ that was annotated using GRCm38.p4 assembly. First column: gene names and chromosomic localizations. Second column: exon composition of the coding sequences and part of the receptor encoded by each exon (open boxes, exons; bridges, splicing events; black boxes, transmembrane domains; curved lines, loops or N- or C-terminal domains; colours, alternative exons). Third column: name and size of the gene products and splice variants (aa, amino acids). Fourth column: size of the complete coding sequence on the human genome (b, bases; kb, kilo bases).

\section{Figure 4. Signaling pathways engaged by 5-HT receptors.}

Only the 5-HT receptors $\left(5-\mathrm{HT}_{1 \mathrm{~A}}, 5-\mathrm{HT}_{2 \mathrm{~A}}, 5-\mathrm{HT}_{2 \mathrm{C}}, 5-\mathrm{HT}_{4}, 5-\mathrm{HT}_{6}\right.$ and $5-\mathrm{HT}_{7}$ receptors) for which signal transduction mechanisms have been extensively characterized, including in authentic tissues, are depicted. cAMP, cyclic adenosine monophosphate; Cdk5, cyclindependent kinase 5; Epac, Exchange protein directly activated by cAMP; ERK, Extracellular 
signal-regulated kinase; FGFR2, Fibroblast Growth Factor Receptor 2; $\mathrm{gCa}^{2+}$, calcium conductance; $\mathrm{gK}^{+}$, potassium conductance; GIRK, G protein-coupled inwardly-rectifying potassium channel; Jab1, c-Jun activation domain-binding protein-1; Jak2, Janus kinase 2; MMP9, Matrix metalloproteinase 9; mTOR, mammalian Target Of Rapamycin; mTORC1, mTOR Complex 1; NF1, neurofibromin; PLA2, Phospholipase A2; PLC, phospholipase C; PLD1, phospholipase D1; PKC, protein kinase C; Ras-GRF1, Guanine nucleotide exchange factor for Ras; STAT3, Signal Transducer and Activator of Transcription 3. 


\begin{tabular}{|c|c|c|c|c|c|c|}
\hline Receptor 1 & Receptor 2 & $\begin{array}{l}\text { Demonstration of } \\
\text { interaction in vitro }\end{array}$ & $\begin{array}{l}\text { Demonstration of } \\
\text { interaction in vivo }\end{array}$ & Impact on signaling & $\begin{array}{c}\text { Physiological / } \\
\text { pathological roles }\end{array}$ & References \\
\hline $5-\mathrm{HT}_{1 \mathrm{~A}}$ & $5-\mathrm{HT}_{2 \mathrm{~A}}$ & PLA, BRET & $\begin{array}{l}\text { PLA (CA1-CA3 } \\
\text { regions of } \\
\text { hippocampus) } \\
\end{array}$ & $\begin{array}{l}\uparrow \text { ipsapirone binding } \\
\uparrow \mathrm{G}_{\mathrm{i} / \mathrm{o}} \text { coupling }\end{array}$ & Depression & $\begin{array}{c}\text { (Borroto-Escuela et al., } \\
\text { 2017) }\end{array}$ \\
\hline $5-\mathrm{HT}_{1 \mathrm{~A}}$ & $5-\mathrm{HT}_{7}$ & Co-IP, FRET & & $\begin{array}{c}\downarrow \mathrm{G}_{\mathrm{i}} \text { protein activation } \\
\uparrow \mathrm{ERK} 1 / 2 \text { activation } \\
\uparrow 5-\mathrm{HT}_{1 \mathrm{~A}} \text { receptor } \\
\text { internalization } \\
\end{array}$ & & (Renner et al., 2012) \\
\hline $5-\mathrm{HT}_{2 \mathrm{~A}}$ & $5-\mathrm{HT}_{2 \mathrm{C}}$ & LCA, PLA, BRET & & & Motor impulsivity & $\begin{array}{l}\text { (Anastasio et al., 2015; } \\
\text { Felsing et al., 2018) }\end{array}$ \\
\hline $5-\mathrm{HT}_{2 \mathrm{~A} / \mathrm{B}}$ & $5-\mathrm{HT}_{2 \mathrm{C}}$ & Co-IP, BRET & & $\begin{array}{l}\text { Blunts } 5-\mathrm{HT}_{2 \mathrm{~A}} \text { and } 5-\mathrm{HT}_{2 \mathrm{~B}} \\
\text { receptor-operated signaling }\end{array}$ & & (Moutkine et al., 2017) \\
\hline $5-\mathrm{HT}_{1 \mathrm{~A}}$ & GalR $_{1}$ & FRET & & $\begin{array}{l}\text { Reciprocal allosteric } \\
\text { antagonistic action }\end{array}$ & & $\begin{array}{c}\text { (Borroto-Escuela, Narvaez, } \\
\text { et al., 2010; Flores-Burgess } \\
\text { et al., 2017; Millon et al., } \\
\text { 2016) }\end{array}$ \\
\hline $5-\mathrm{HT}_{1 \mathrm{~A}}$ & GPR39 & BRET, Co-IP & & $\begin{array}{l}\uparrow \text { ERK } 1 / 2 \text { activation } \\
\text { and NFK } \beta \text {-signaling }\end{array}$ & Depression & (Tena-Campos et al., 2015) \\
\hline $5-\mathrm{HT}_{1 \mathrm{~A}}$ & $\mathrm{D}_{2}$ & $\begin{array}{l}\text { BRET, FLIM, } \\
\text { FRET, HTRF }\end{array}$ & $\begin{array}{c}\text { PLA } \\
\text { (prefrontal cortex) }\end{array}$ & $\begin{array}{c}\text { Cross talk in } \\
\text { ERK activation }\end{array}$ & & $\begin{array}{c}\text { (Kolasa et al., 2018; } \\
\text { Lukasiewicz et al., 2016) }\end{array}$ \\
\hline $5-\mathrm{HT}_{1 \mathrm{~A}}$ & MOR & $\begin{array}{l}\text { Co-IP, BRET, } \\
\text { transactivation }\end{array}$ & & $\begin{array}{c}5-\mathrm{HT}_{1 \mathrm{~A}} \text { receptor } \\
\text { transactivation } \\
\downarrow \text { MOR-operated ERK1/2 } \\
\text { activation }\end{array}$ & & (Cussac et al., 2012) \\
\hline $5-\mathrm{HT}_{2 \mathrm{~A} / 2 \mathrm{C}}$ & CRFR1 & & $\begin{array}{l}\text { Co-localization } \\
\text { interfering peptide } \\
\text { (prefrontal cortex) }\end{array}$ & $\uparrow$ receptor recycling & Anxiety & $\begin{array}{l}\text { (Magalhaes et al., 2010; } \\
\text { Narla et al., 2015) }\end{array}$ \\
\hline $5-\mathrm{HT}_{2 \mathrm{~A}}$ & $\mathrm{mGlu}_{2}$ & $\begin{array}{c}\text { Genetically encoded } \\
\text { photo cross-linkers }\end{array}$ & Co-IP (cortex) & $\begin{array}{c}\downarrow \mathrm{G}_{\mathrm{q}}-\mathrm{PLC} \text { signaling, } \\
\uparrow \mathrm{G}_{\mathrm{i} / \mathrm{o}} \text { signaling }\end{array}$ & $\begin{array}{c}\text { Response to } \\
\text { hallucinogens and }\end{array}$ & $\begin{array}{l}\text { (Benvenga et al., 2018; } \\
\text { Fribourg et al., 2011; }\end{array}$ \\
\hline
\end{tabular}




\begin{tabular}{|c|c|c|c|c|c|c|}
\hline & & $\begin{array}{l}\text { Mutants defective } \\
\text { for interaction } \\
\text { Co-IP, FRET }\end{array}$ & & & $\begin{array}{l}\text { antipsychotics, } \\
\text { schizophrenia }\end{array}$ & $\begin{array}{c}\text { Gonzalez-Maeso et al., 2008; } \\
\text { Murat et al., 2018) }\end{array}$ \\
\hline $5-\mathrm{HT}_{2 \mathrm{~A}}$ & $\mathrm{CB}_{1}$ & BRET & $\begin{array}{l}\text { PLA, Interfering } \\
\text { peptide } \\
\text { (hippocampus, } \\
\text { cortex, striatum) }\end{array}$ & $\begin{array}{c}\downarrow 5-\mathrm{HT}_{2 \mathrm{~A}} \text { receptor coupling } \\
\text { to } \mathrm{G}_{\mathrm{q}} \\
\uparrow 5-\mathrm{HT}_{2 \mathrm{~A}} \text { receptor } \\
\text { coupling to } \mathrm{Gi}\end{array}$ & $\begin{array}{l}\text { THC-induced } \\
\text { memory } \\
\text { impairment }\end{array}$ & (Vinals et al., 2015) \\
\hline $5-\mathrm{HT}_{2 \mathrm{~A}}$ & $\mathrm{D}_{2}$ & BRET, PLA & $\begin{array}{l}\text { PLA (ventral and } \\
\text { dorsal striatum) }\end{array}$ & $\begin{array}{l}\uparrow \mathrm{D}_{2} \text { receptor signaling by } \\
\text { hallucinogenic 5-HT } 2 \mathrm{~A} \\
\text { receptor agonists } \\
\uparrow 5 \text { - } \mathrm{HT}_{2 \mathrm{~A}} \text {-receptor } \\
\text { mediated PLC activation }\end{array}$ & & $\begin{array}{c}\text { (Borroto-Escuela et al. 2010, } \\
\text { 2014) }\end{array}$ \\
\hline $5-\mathrm{HT}_{2 \mathrm{C}}$ & $\mathrm{MT}_{2}$ & Co-IP, BRET & $\begin{array}{l}\text { Co-IP (cortex, } \\
\text { hippocampus, } \\
\text { choroid plexus) }\end{array}$ & $\begin{array}{l}5-\mathrm{HT}_{2 \mathrm{C}} \text { receptor } \\
\text { transactivation }\end{array}$ & & (Kamal et al., 2015) \\
\hline $5-\mathrm{HT}_{2 \mathrm{C}}$ & GHS-R $1 \mathrm{a}$ & fcFRET & $\begin{array}{c}\text { Co-localization } \\
\text { (hypothalamic and } \\
\text { hippocampal } \\
\text { neurons) }\end{array}$ & $\downarrow \mathrm{Ca}^{2+}$ signaling & & (Schellekens et al., 2015) \\
\hline
\end{tabular}

Table 1. 5-HT receptor heteromerization. The name of partner receptors, the methods used to demonstrate heteromerization in vitro and in vivo, its impact on receptor signal transduction properties and its physiological/pathological consequences are indicated. PLA, proximity ligation assay; LCA, luciferase complementation assay; BRET, bioluminescence resonance energy transfer; fcFRET, flow cytometry fluorescence resonance energy transfer, HTRF, homogeneous time-resolved fluorescence; FLIM, fluorescence-lifetime imaging microscopy. 


\begin{tabular}{|c|c|c|c|c|}
\hline Receptor & Partner & Binding site & Function of the identified interaction & References \\
\hline $5-\mathrm{HT}_{1 \mathrm{~A}}$ & $\begin{array}{l}\text { Calmodulin } \\
\text { Yif1B }\end{array}$ & $\begin{array}{l}\text { Intracellular loop } \\
\text { C-terminus }\end{array}$ & $\begin{array}{c}\text { Trafficking, signaling } \\
\text { Trafficking, dendritic targeting }\end{array}$ & $\begin{array}{l}\text { (Turner et al., 2004) } \\
\text { Carrel et al. 2008; Al Awabdh et al. 2012) }\end{array}$ \\
\hline $5-\mathrm{HT}_{1 \mathrm{~B}}$ & p11 & Intracellular loop & \begin{tabular}{|c|} 
Increases receptor cell surface \\
expression and function, response to L- \\
DOPA treatment, emotional memory \\
\end{tabular} & $\begin{array}{c}\text { Svenningsson et al., 2006; Zhang et al. 2008; } \\
\text { Eriksson et al., 2013) }\end{array}$ \\
\hline $5-\mathrm{HT}_{2 \mathrm{~A}}$ & $\begin{array}{l}\text { PDZ proteins* } \\
\text { PSD-95 } \\
\\
\text { MUPP1 } \\
\text { SAP97 } \\
\text { MAGI1-3 } \\
\text { MPP3 } \\
\text { CIPP } \\
\text { PDZK1/NHERF3 } \\
\text { Caveolin } \\
\text { ARF1-6 } \\
\text { PLD1 } \\
\text { Ribosomal S6 kinase } \\
\text { Calmodulin }\end{array}$ & $\begin{array}{l}\text { C-terminus } \\
\text { C-terminus } \\
\\
\text { C-terminus } \\
\text { C-terminus } \\
\text { C-terminus } \\
\text { C-terminus } \\
\text { C-terminus } \\
\text { Intracellular loop } \\
\text { Intracellular loop } \\
\text { Intracellular loop } \\
\text { Intracellular loop } \\
\text { C-terminus / } \\
\text { intracellular loop }\end{array}$ & \begin{tabular}{|c|} 
Targeting to dendrites \\
Trafficking, signaling, response to \\
antipsychotics, neuropathic pain \\
Trafficking, signaling \\
Internalization, signaling \\
Trafficking, signaling \\
Signaling \\
Signaling \\
Signaling \\
Receptor phosphorylation / Signaling \\
Receptor phosphorylation / \\
desensitization \\
\end{tabular} & $\begin{array}{c}\text { (Xia et al., 2003b) } \\
\text { (Xia et al., 2003a; Becamel et al. 2002, 2004; } \\
\text { Abbas et al. 2009, Pichon et al., 2009, Vogrig et } \\
\text { al., 2013) } \\
\text { (Becamel et al., 2001) } \\
\text { (Becamel et al., 2004; Dunn et al. 2014) } \\
\text { (Becamel et al., 2004, Hammad et al., 2018) } \\
\text { (Becamel et al., 2004) } \\
\text { (Becamel et al., 2004) } \\
\text { (Walther et al., 2015) } \\
\text { (Bhatnagar et al., 2004; Cogolludo et al., 2006) } \\
\text { (Robertson et al., 2003) } \\
\text { (Felder et al., 1999) } \\
\text { (Sheffler et al., 2006) } \\
\text { (Turner \& Raymond, 2005) }\end{array}$ \\
\hline $5-\mathrm{HT}_{2 \mathrm{~B}}$ & $\begin{array}{l}\text { PDZ proteins* } \\
\text { MUPP1 }\end{array}$ & & NO signaling & $\begin{array}{l}\text { (Manivet et al. 2000) } \\
\text { (Becamel et al. 2001) }\end{array}$ \\
\hline $5-\mathrm{HT}_{2 \mathrm{C}}$ & $\begin{array}{l}\text { MUPP1 } \\
\text { PSD-95 } \\
\text { SAP97 }\end{array}$ & $\begin{array}{l}\text { C-terminus } \\
\text { C-terminus } \\
\text { C-terminus }\end{array}$ & $\begin{array}{c}\text { Receptor clustering, phosphorylation } \\
\text { Trafficking }\end{array}$ & $\begin{array}{l}\text { (Ulmer et al., 1998; Bécamel et al., 2001; } \\
\text { Parker et al. 2003) } \\
\text { (Becamel et al., 2002, 2004) } \\
\text { (Becamel et al., 2004) }\end{array}$ \\
\hline
\end{tabular}

- 74 - 


\begin{tabular}{|c|c|c|c|c|}
\hline & $\begin{array}{l}\text { SAP102 } \\
\text { MAGI2 } \\
\text { MPP3 } \\
\text { Veli3/CASK/Mint1 } \\
\text { Calmodulin } \\
\text { PTEN } \\
\text { Ahi1 } \\
\text { CHL1 }\end{array}$ & $\begin{array}{l}\text { C-terminus } \\
\text { C-terminus } \\
\text { C-terminus } \\
\text { C-terminus } \\
\text { C-terminus } \\
\text { Intracellular loop } \\
\text { Intracellular loop }\end{array}$ & $\begin{array}{c}\text { Trafficking } \\
\text { G protein-independent signaling } \\
\text { Receptor dephosphorylation, } \\
\text { behavioral responses to drugs of abuse } \\
\text { Receptor degradation } \\
\text { Signaling }\end{array}$ & $\begin{array}{c}\text { (Becamel et al., 2004) } \\
\text { (Becamel et al., 2004) } \\
\text { (Becamel et al., 2002, 2004) } \\
\text { (Becamel et al., 2002, 2004) } \\
\text { (Becamel et al., 2002, Labasque et al., 2006) } \\
\text { (Ji et al., 2006) } \\
\text { (Wang et al., 2012) } \\
\text { (Kleene et al., 2015) }\end{array}$ \\
\hline $5-\mathrm{HT}_{4}$ & $\begin{array}{c}\text { P11 } \\
\text { Src } \\
\text { APP/ADAM10 }\end{array}$ & Intracellular loop & $\begin{array}{l}\text { Trafficking, signaling, behavioral } \\
\text { response to antidepressants } \\
\beta \text {-arrestin-independent ERK1/2 } \\
\text { activation } \\
\text { Non-amyloidogenic APP processing }\end{array}$ & $\begin{array}{c}\text { (Meschin et al., 2015; Warner-Schmidt et al., } \\
\text { 2009) } \\
\text { (Barthet et al., 2009) } \\
\text { (Cochet et al., 2013) }\end{array}$ \\
\hline $5-\mathrm{HT}_{4(\mathrm{a})}$ & $\begin{array}{c}\text { SNX27 } \\
\text { NHERF-1 (EBP50) } \\
\text { MAGI2 } \\
\text { MPP3 } \\
\text { Veli1-3 } \\
\text { CRMP2 }\end{array}$ & $\begin{array}{l}\text { C-terminus } \\
\text { C-terminus } \\
\text { C-terminus } \\
\text { C-terminus } \\
\text { C-terminus } \\
\text { C-terminus }\end{array}$ & $\begin{array}{l}\text { Targeting, trafficking } \\
\text { Targeting }\end{array}$ & $\begin{array}{l}\text { (Joubert et al., 2004) } \\
\text { (Joubert et al., 2004) } \\
\text { (Joubert et al., 2004) } \\
\text { (Joubert et al., 2004) } \\
\text { (Joubert et al., 2004) } \\
\text { (Joubert et al., 2004) }\end{array}$ \\
\hline $5-\mathrm{HT}_{4(\mathrm{~d})}$ & GPRIN2 & & Signaling & (Sokolina et al., 2017) \\
\hline $5-\mathrm{HT}_{4}(\mathrm{e})$ & $\begin{array}{l}\text { CIPP } \\
\text { nNOS } \\
\text { Sec23 } \\
\end{array}$ & $\begin{array}{l}\text { C-terminus } \\
\text { C-terminus } \\
\text { C-terminus } \\
\end{array}$ & & $\begin{array}{l}\text { (Joubert et al., 2004) } \\
\text { (Joubert et al., 2004) } \\
\text { (Joubert et al., 2004) }\end{array}$ \\
\hline $5-\mathrm{HT}_{6}$ & $\begin{array}{l}\text { Fyn } \\
\text { Jab } 1 \\
\text { mTOR } \\
\text { Rheb }\end{array}$ & $\begin{array}{l}\text { C-terminus } \\
\text { Intracellular loop / } \\
\text { C-terminus } \\
\text { Intracellular loop / } \\
\text { C-terminus } \\
\text { C-terminus }\end{array}$ & $\begin{array}{c}\text { Signaling } \\
\text { Trafficking, signaling } \\
\text { Signaling, cognition, epileptic seizures } \\
\text { Signaling }\end{array}$ & $\begin{array}{c}\text { (Yun et al., 2007) } \\
\text { (Yun et al., 2010) } \\
\text { (Meffre et al., 2012; Wang et al., 2015) } \\
\text { (Meffre et al., 2012) }\end{array}$ \\
\hline
\end{tabular}




\begin{tabular}{|c|c|c|c|c|}
\hline & $\begin{array}{c}\text { Raptor } \\
\text { Tti1 } \\
\text { Tel2 } \\
\text { Cdk5 } \\
\text { Map1b } \\
\text { Neurofibromin } \\
\text { SNX14 }\end{array}$ & $\begin{array}{c}\text { C-terminus } \\
\text { C-terminus } \\
\text { C-terminus } \\
\text { Intracellular loop }\end{array}$ & $\begin{array}{l}\text { Neuronal migration, neurite growth } \\
\text { Trafficking, signaling } \\
\text { Agonist-independent Gs signaling } \\
\text { Receptor internalization/degradation }\end{array}$ & $\begin{array}{c}\text { (Meffre et al., 2012) } \\
\text { (Meffre et al., 2012) } \\
\text { (Meffre et al., 2012) } \\
\text { (Duhr et al., 2014; Jacobshagen et al., 2014) } \\
\text { (Kim et al., 2014) } \\
\text { (Deraredj-Nadim et al., 2016) } \\
\text { (Ha et al., 2015) }\end{array}$ \\
\hline $5-\mathrm{HT}_{7}$ & $\begin{array}{l}\text { RhoBTB3 } \\
\text { S100B } \\
\text { CD44 }\end{array}$ & $\begin{array}{c}\text { C-terminus } \\
\text { Intracellular loop }\end{array}$ & $\begin{array}{c}\text { Receptor stability } \\
\text { Behavioral response to fluoxetine } \\
\text { Dendritic spine remodeling, synaptic } \\
\text { pruning and impairment of LTP }\end{array}$ & $\begin{array}{c}\text { (Matthys et al., 2010) } \\
\text { (Stroth \& Svenningsson, 2015) } \\
\text { (Bijata et al., 2017) }\end{array}$ \\
\hline
\end{tabular}

Table 2. 5-HT receptor interacting proteins and their impact upon receptor signal transduction and functions. Only receptor subtypes for which interacting proteins have been unambiguously identified are mentioned. * Refers to experiments in which the receptor PDZ binding motif has been deleted. 
Classification of serotonin receptors: an historic view

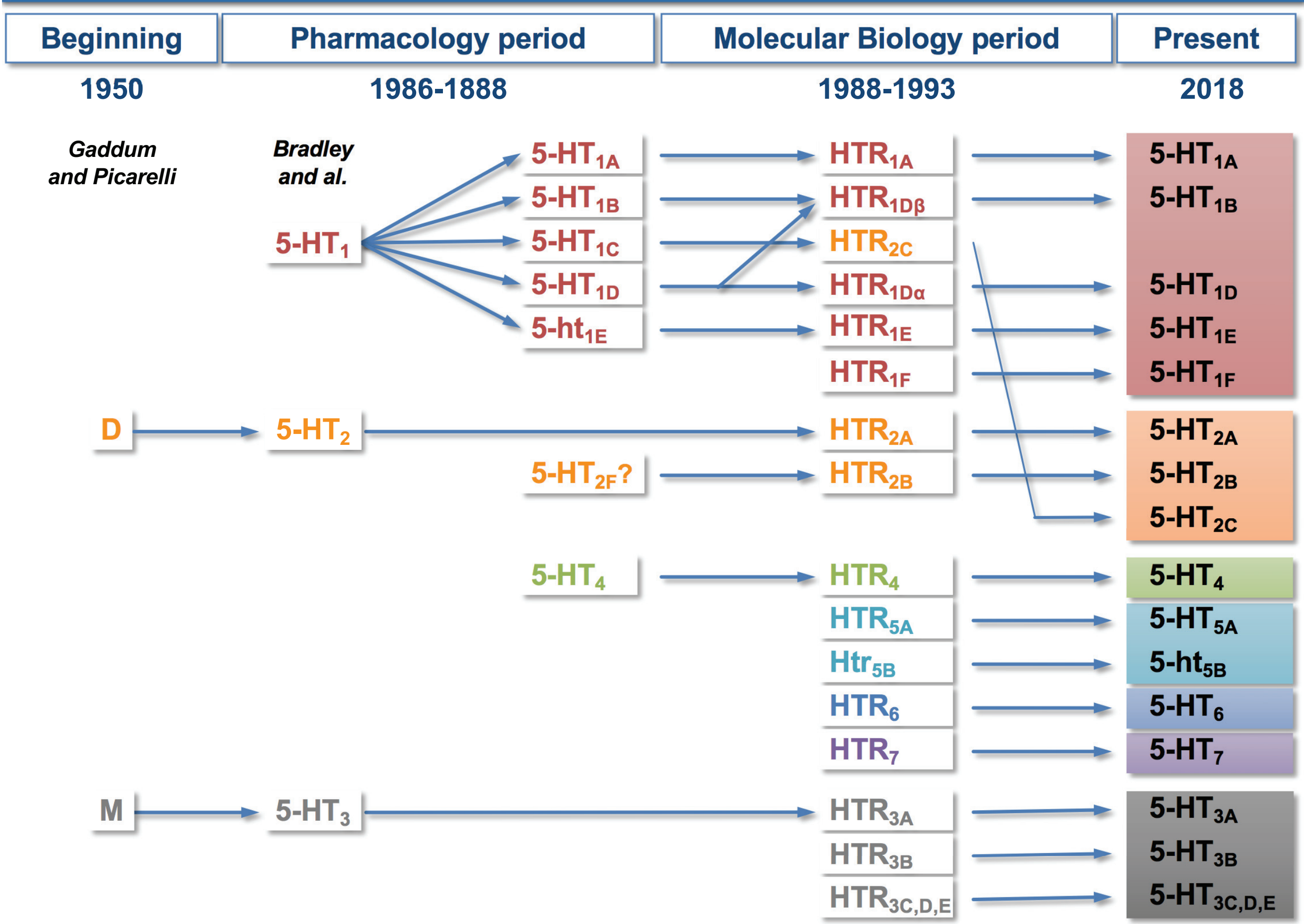


A

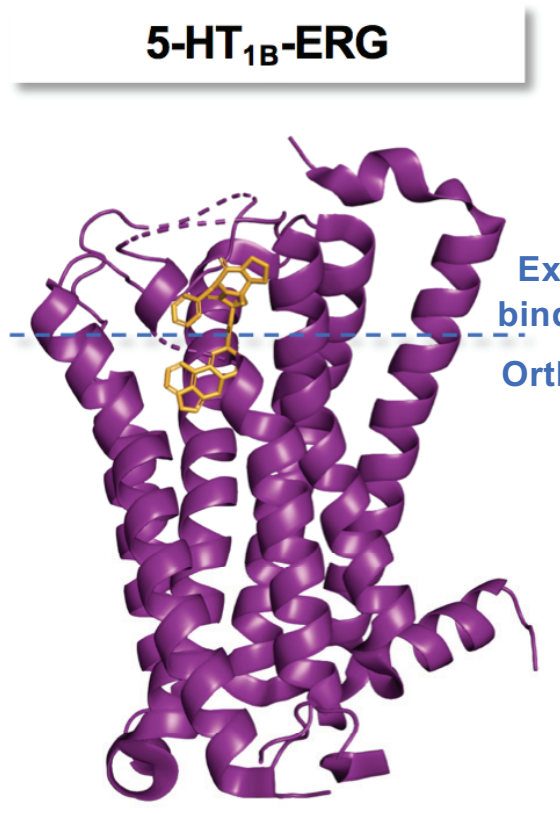

C

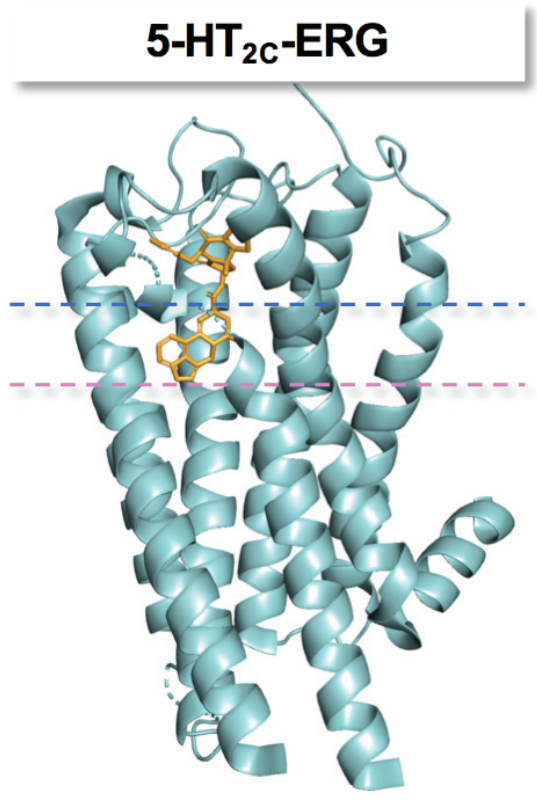

B

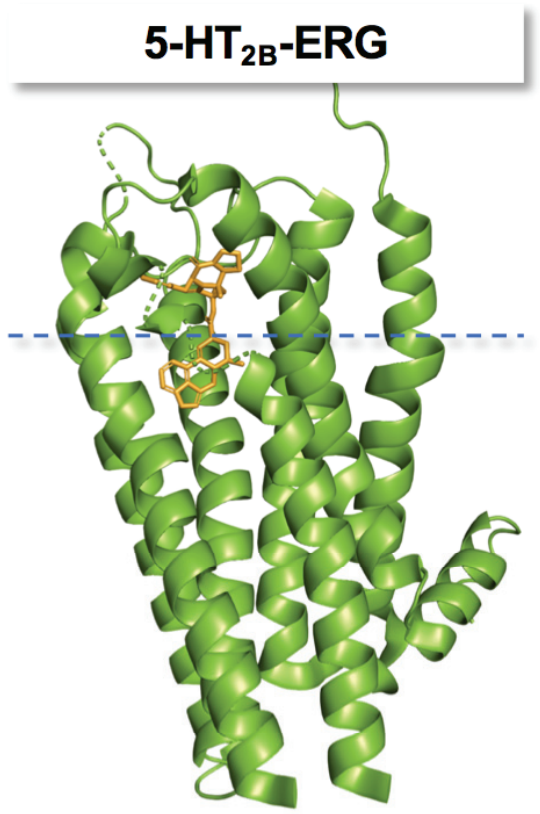

D

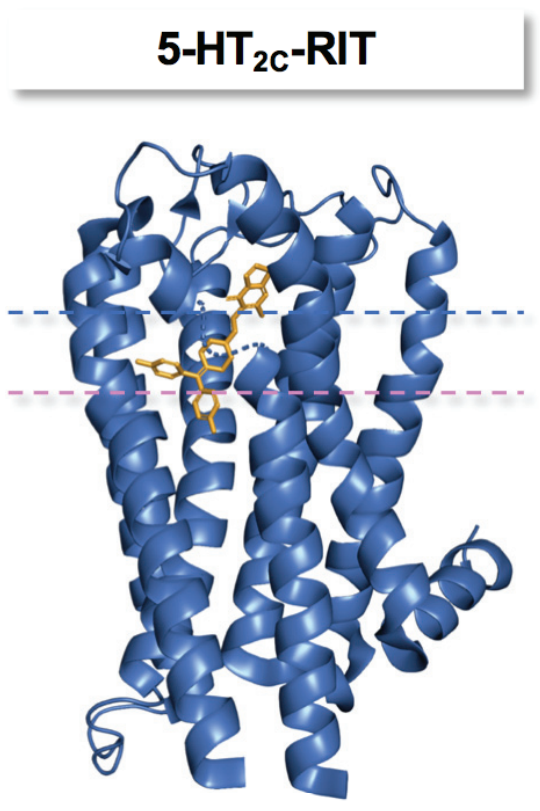




\begin{tabular}{|c|c|c|c|}
\hline Gene & Gene strt & Gene products & Cds \\
\hline $\begin{array}{l}\text { HTR1A } \\
5 q 12.3\end{array}$ & ए & 5-HT1A: 422aa & $1269 b$ \\
\hline $\begin{array}{l}\text { HTR1B } \\
6 q 14.1\end{array}$ & $\square$ & $5-\mathrm{HT}_{1 \mathrm{~B}}: 390 \mathrm{aa}$ & $1173 b$ \\
\hline $\begin{array}{l}\text { HTR1D } \\
1 \mathrm{p} 36.12\end{array}$ & $\square$ & 5-HT1D: $377 \mathrm{aa}$ & $1134 b$ \\
\hline $\begin{array}{l}\text { HTR1E } \\
6 q 14.3\end{array}$ & $\square$ & 5-HT1E: 365aa & $1098 b$ \\
\hline $\begin{array}{l}\text { HTR1F } \\
3 p 11.2-p 11.1\end{array}$ & $\sqsubset$ & 5-HT1F: 366aa & $1101 b$ \\
\hline $\begin{array}{l}\text { HTR2A } \\
13 q 14.2\end{array}$ & U & $5-\mathrm{HT}_{2 \mathrm{~A}}: 471 \mathrm{aa}$ & $>65 \mathrm{~kb}$ \\
\hline $\begin{array}{l}\text { HTR2B } \\
2 q 37.1\end{array}$ & U & $5-\mathrm{HT}_{2 \mathrm{~B}}: 481 \mathrm{aa}$ & $>17 \mathrm{~kb}$ \\
\hline $\begin{array}{l}\text { HTR2C } \\
\text { Xq23 }\end{array}$ & 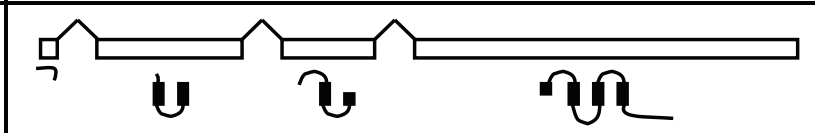 & $5-\mathrm{HT}_{2 \mathrm{C}}: 458 \mathrm{aa}$ & $>325 \mathrm{~kb}$ \\
\hline $\begin{array}{l}\text { HTR3A } \\
11 q 23.2\end{array}$ & 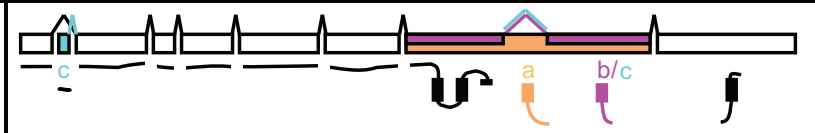 & $\begin{array}{c}5-\mathrm{HT}_{3 \mathrm{~A}(\mathrm{a}):}: 510 \mathrm{aa} \\
(\mathrm{b}): 478 \mathrm{aa},(\mathrm{c}): 463 \mathrm{aa}\end{array}$ & $>15 \mathrm{~kb}$ \\
\hline $\begin{array}{l}\text { HTR3B } \\
11 q 23.2\end{array}$ & 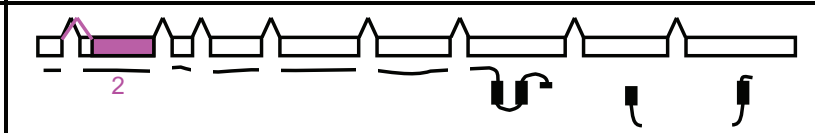 & $\begin{array}{l}5-\mathrm{HT}_{3 \mathrm{~B}(1)}: 441 \mathrm{aa} \\
5-\mathrm{HT}_{3 \mathrm{~B}(2):}: 430 \mathrm{aa}\end{array}$ & $>50 \mathrm{~kb}$ \\
\hline $\begin{array}{l}\text { HTR3C } \\
3 q 27.1\end{array}$ & 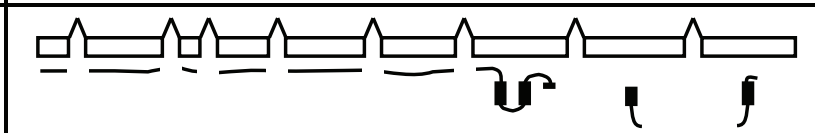 & 5-HT3c: 447aa & $>7 \mathrm{~kb}$ \\
\hline $\begin{array}{l}\text { HTR3D } \\
3 q 27.1\end{array}$ & 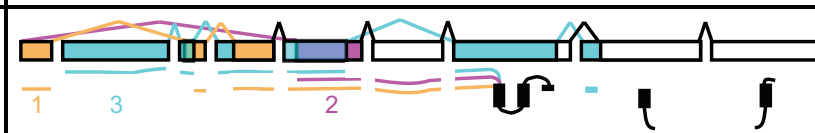 & $\begin{array}{c}5-\mathrm{HT}_{3 \mathrm{D}(1):} \text { 404aa } \\
(2): 279 \mathrm{aa},(3): 454 \mathrm{aa}\end{array}$ & $>7 \mathrm{~kb}$ \\
\hline $\begin{array}{l}\text { HTR3E } \\
3 q 27.1\end{array}$ & 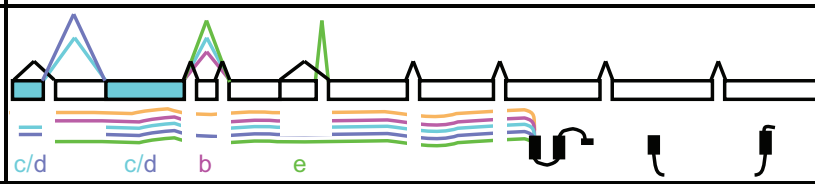 & $\begin{array}{c}\text { 5-HT3E(a): 471aa } \\
\text { (b): 456aa, (c): 441aa } \\
\text { (d): 456aa, (e): 482aa }\end{array}$ & $>6 \mathrm{~kb}$ \\
\hline $\begin{array}{l}\text { HTR4 } \\
5 q 32\end{array}$ & 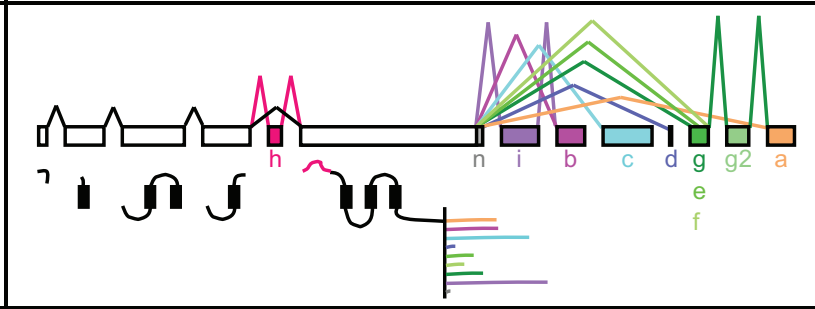 & $\begin{array}{c}\text { 5-HT } 4(\mathrm{a}): 387 \mathrm{aa} \\
\text { (b): } 388 \mathrm{aa},(\mathrm{c}): 411 \mathrm{aa}, \\
\text { (d): } 360 \mathrm{aa},(\mathrm{e}): 371 \mathrm{aa}, \\
\text { (f): } 363 \mathrm{aa},(\mathrm{g}): 378 \mathrm{aa}, \\
\text { (hb): 402aa, (i): 428aa, } \\
\text { (n):359aa }\end{array}$ & $>203 \mathrm{~kb}$ \\
\hline $\begin{array}{l}\text { HTR5A } \\
7 q 36.2\end{array}$ & यथि & $5-\mathrm{HT}_{5 \mathrm{~A}}: 357 \mathrm{aa}$ & $>17 \mathrm{~kb}$ \\
\hline $\begin{array}{l}\text { Htr5b } \\
2 q 14.1\end{array}$ & & Pseudogene & none \\
\hline $\begin{array}{l}\text { HTR6 } \\
1 \mathrm{p} 36.13\end{array}$ & ton & $5-\mathrm{HT}_{6}: 440 \mathrm{aa}$ & $>15 \mathrm{~kb}$ \\
\hline $\begin{array}{l}\text { HTR7 } \\
\text { 10q23.31 }\end{array}$ & 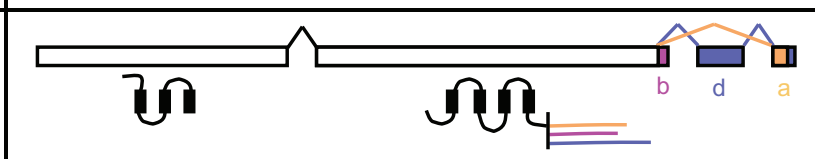 & $\begin{array}{l}5-\mathrm{HT}_{7(\mathrm{a})}: 445 \mathrm{aa} \\
5-\mathrm{HT}_{7(\mathrm{~b})}: \text { 432aa } \\
5-\mathrm{HT}_{7(\mathrm{~d})}: 479 \mathrm{aa}\end{array}$ & $>119 \mathrm{~kb}$ \\
\hline
\end{tabular}




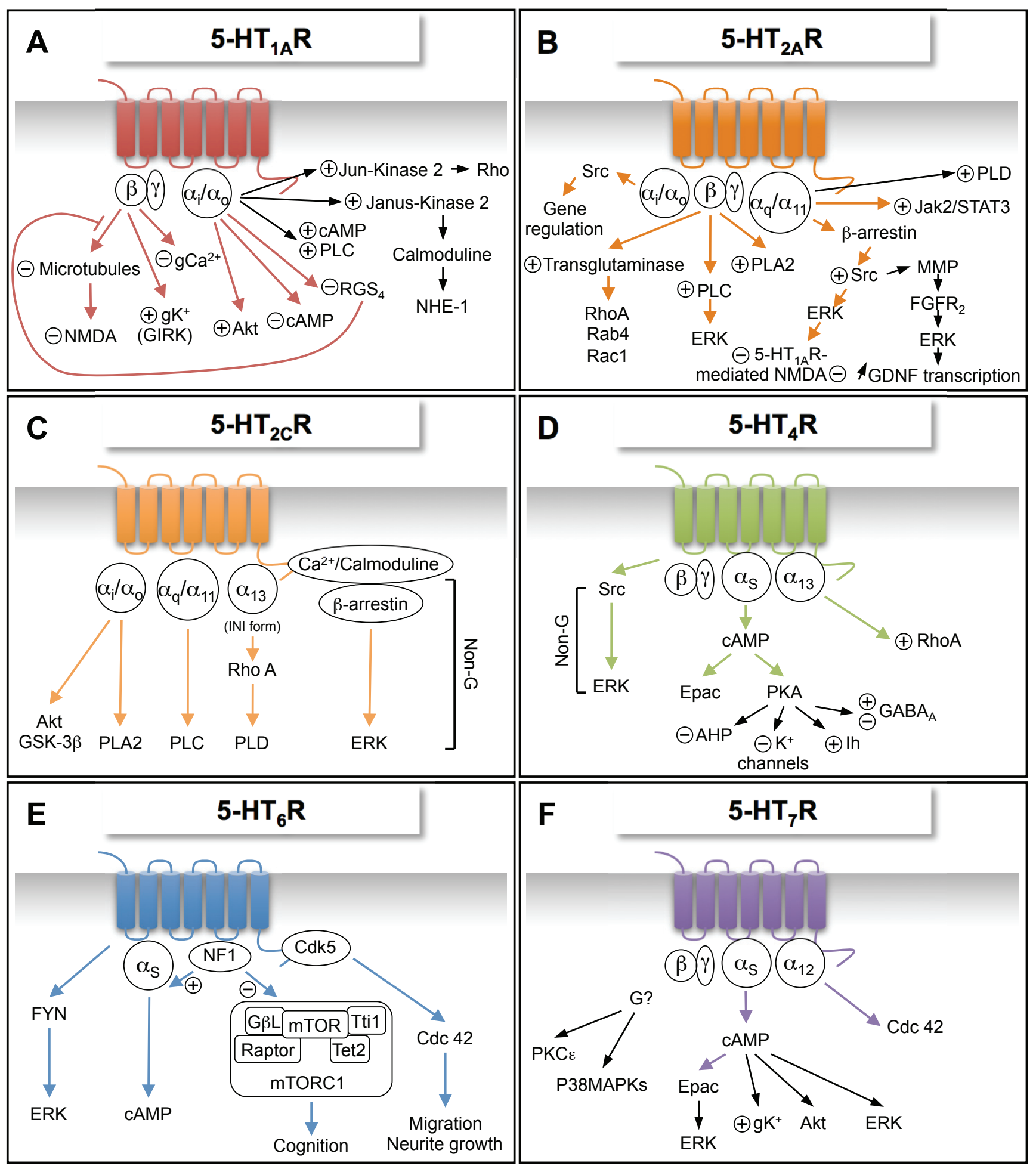

